September 2001 • NREL/TP-550-27754

\title{
Building America House Performance Analysis Procedures
}

R. Hendron, S. Farrar-Nagy, R. Anderson, R. Judkoff

National Renewable Energy Laboratory

P. Reeves

Partnership for Resource Conservation

E. Hancock

Mountain Energy Partnership

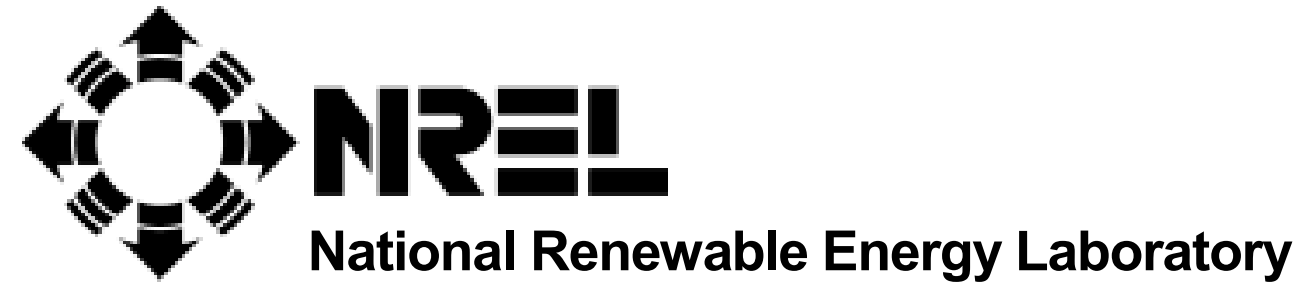

1617 Cole Boulevard

Golden, Colorado 80401-3393

NREL is a U.S. Department of Energy Laboratory

Operated by Midwest Research Institute $\bullet$ Battelle $\bullet$ Bechtel

Contract No. DE-AC36-99-G010337 


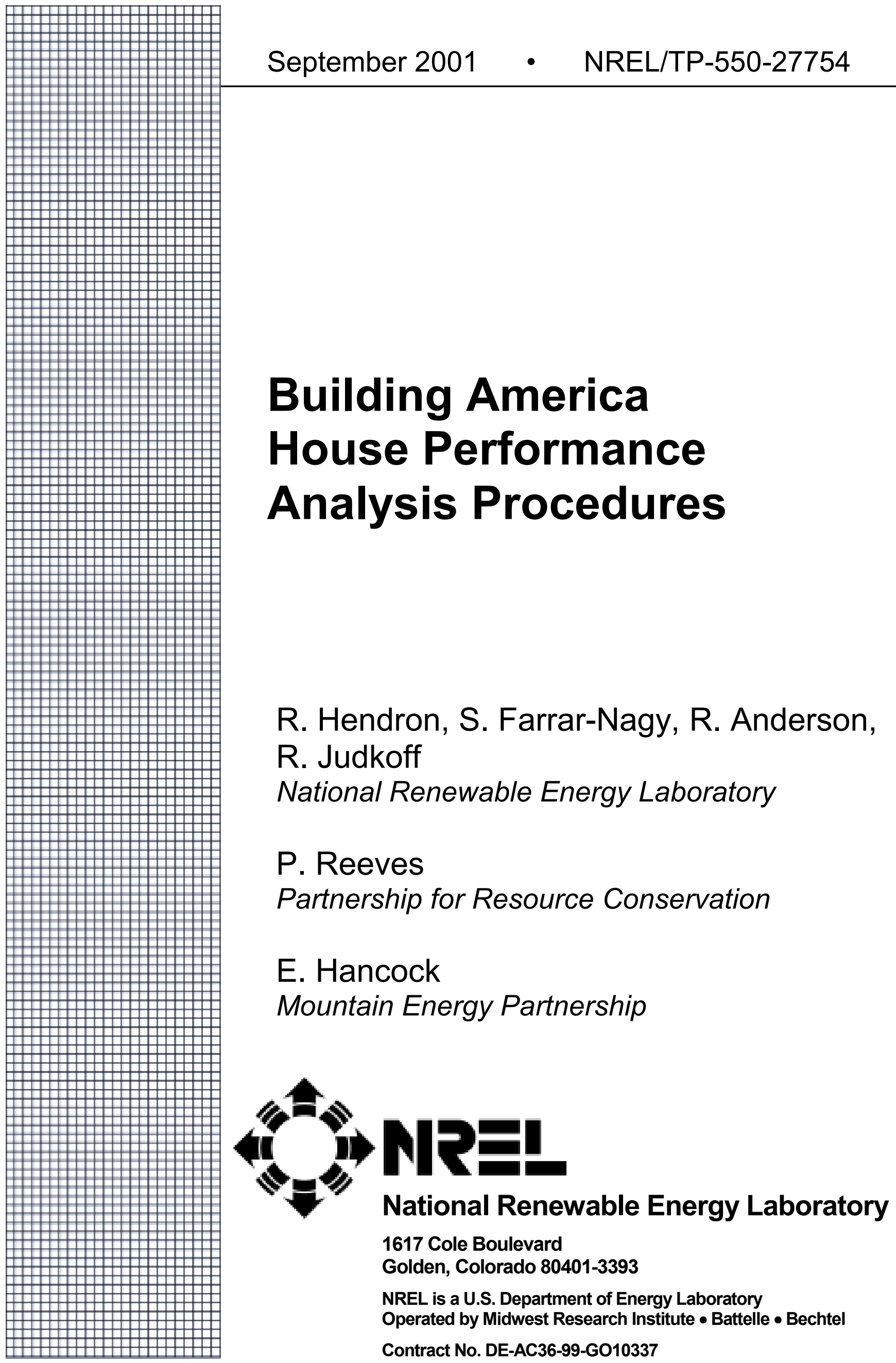




\section{NOTICE}

This report was prepared as an account of work sponsored by an agency of the United States government. Neither the United States government nor any agency thereof, nor any of their employees, makes any warranty, express or implied, or assumes any legal liability or responsibility for the accuracy, completeness, or usefulness of any information, apparatus, product, or process disclosed, or represents that its use would not infringe privately owned rights. Reference herein to any specific commercial product, process, or service by trade name, trademark, manufacturer, or otherwise does not necessarily constitute or imply its endorsement, recommendation, or favoring by the United States government or any agency thereof. The views and opinions of authors expressed herein do not necessarily state or reflect those of the United States government or any agency thereof.

Available electronically at http://www.osti.gov/bridge

Available for a processing fee to U.S. Department of Energy

and its contractors, in paper, from:

U.S. Department of Energy

Office of Scientific and Technical Information

P.O. Box 62

Oak Ridge, TN 37831-0062

phone: 865.576.8401

fax: 865.576.5728

email: reports@adonis.osti.gov

Available for sale to the public, in paper, from:

U.S. Department of Commerce

National Technical Information Service

5285 Port Royal Road

Springfield, VA 22161

phone: 800.553.6847

fax: 703.605.6900

email: orders@ntis.fedworld.gov

online ordering: http://www.ntis.gov/ordering.htm 


\section{Table of Contents}

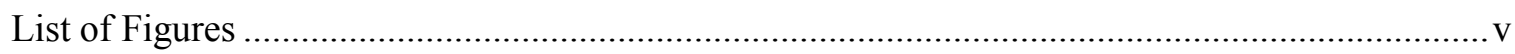

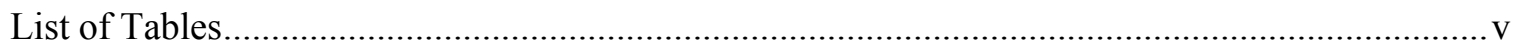

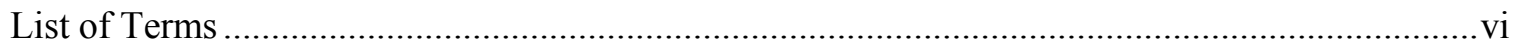

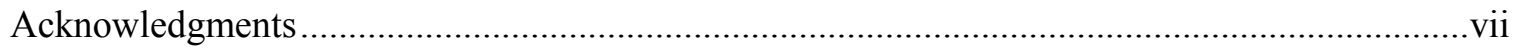

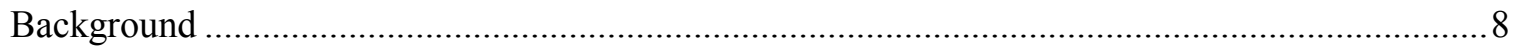

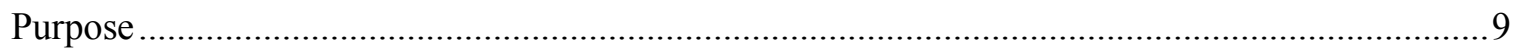

Section I. General Performance Analysis Guidelines …......................................................... 10

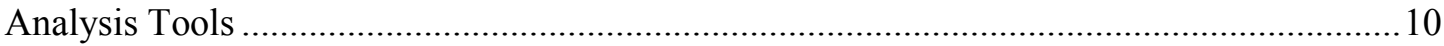

Standard Assumptions Used for Definition of the Base-Case Designs ................................... 10

Standard Assumptions Used for Definition of the Prototype House ........................................ 18

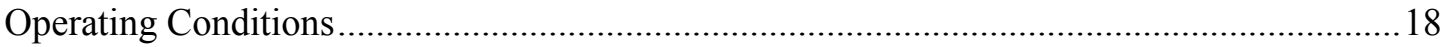

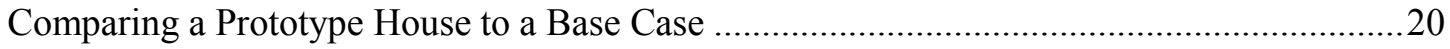

Important Differences Among Base-Case Definitions .......................................................2

Section II. Residential Energy Modeling Approach ............................................................24

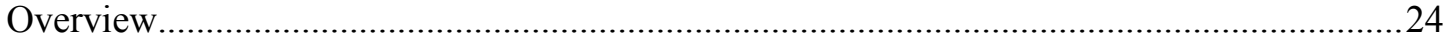

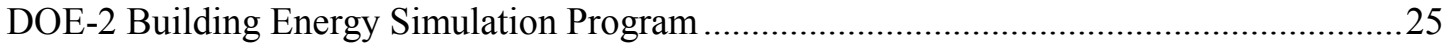

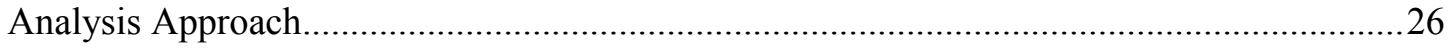

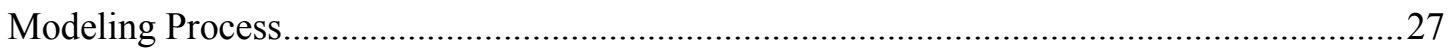

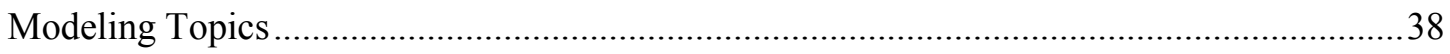

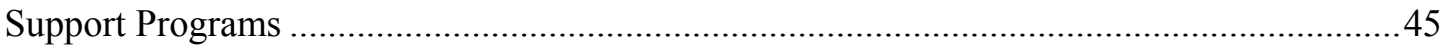

Appendix A. Energy Star Rating Guidelines Using HERS Methodology .................................A-1

Appendix B. Standard Reference House Definitions ........................................................... B-1

Appendix C. Performance Analysis Examples ……............................................................

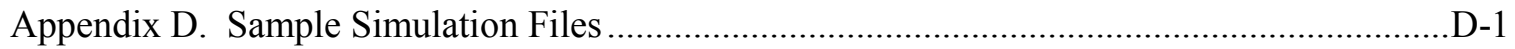




\section{List of Figures}

Figure 1. Comparison of prototoype and base-case house features ........................................24

Figure 2. Example house floor plan containing four spaces .................................................2

Figure 3. Definition of vertices for typical floor plan............................................................29

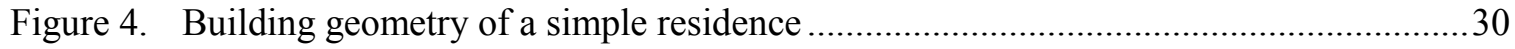

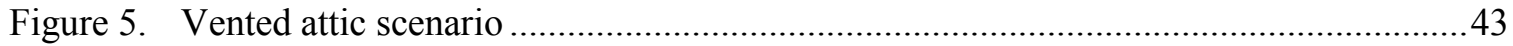

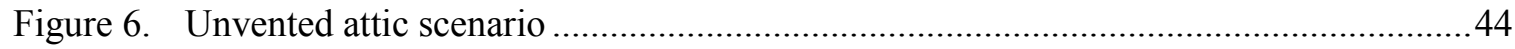

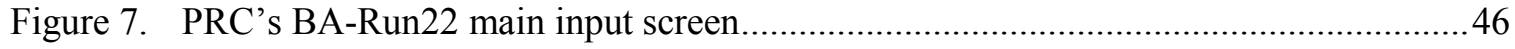

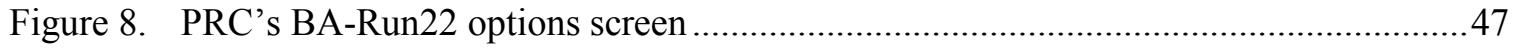

\section{List of Tables}

Table 1. Base-case Heating, Cooling, and Hot-water System Efficiencies...............................13

Table 2. Duct Locations for Regional Standard Practice ....................................................... 14

Table 3. Capacities of Base-case Heating and Cooling Systems............................................... 15

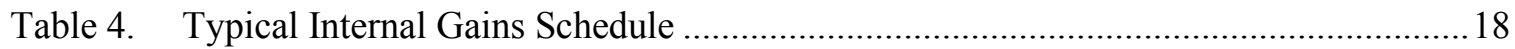

Table 5. Summary of Neutral and Blind Features of the Base Cases......................................22

Table 6. Common Bldg. America Design Changes and Resulting Effect on Energy Usage .....23

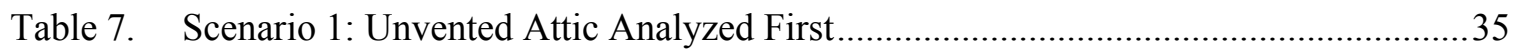

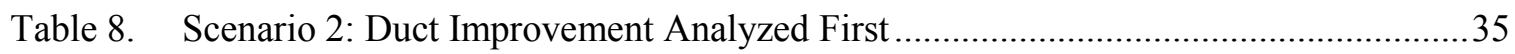

Table 9. Sample Homes Simulation Analysis (with DHW); Front Faces North (as-is),

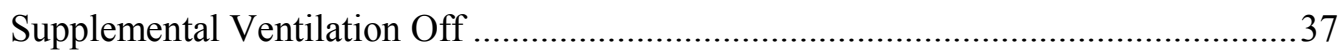




\section{List of Terms}

$\mathrm{ACH}$

$\mathrm{A} / \mathrm{C}$

AFUE

ASHRAE

$\mathrm{B} / \mathrm{C}$

BDL

BESTEST

BSP

CFM

DHW

DOE

EEM

$\mathrm{EF}$

EIR

HERS

HSPF

HVAC

IECC

MBtu

MEC

NAECA

NFRC

NREL

PRC

RSP

R-value

SEER

S-G

TMY

UA

U-value air changes per hour

air-conditioning

annual fuel utilization efficiency

American Society of Heating, Refrigeration and Air-Conditioning Engineers

benefit-to-cost

Building Description Language

Building Energy Simulation Test

builder's standard practice

cubic feet per minute

domestic hot water

U.S. Department of Energy

energy efficiency measure

energy factor

energy input ratio

Home Energy Rating System

heating seasonal performance factor

heating, ventilating, and air-conditioning

International Energy Conservation Code

Million Btu or $10^{6} \mathrm{Btu}$

Model Energy Code

National Appliance Energy Conservation Act of 1987

National Fenestration Rating Council

National Renewable Energy Laboratory

Partnership for Resource Conservation

regional standard practice

measure of resistance to the flow of heat through a given thickness of insulation; higher numbers indicate better insulating properties

seasonal energy efficiency ratio

Sherman-Grimsrud method

typical meteorological year

measure of the building load coefficient

measure of the heat transmission through a building part (as a wall or window) or a given thickness of insulation given in units of $\mathrm{Btu} / \mathrm{hr} \cdot \mathrm{ft}^{2} \cdot{ }^{\circ} \mathrm{F}$; lower numbers indicate better insulating properties 


\section{Acknowledgments}

The authors would like to thank Dick Tracey for laying the groundwork for this document, and Paul Torcellini, Michael Smith, Craig Christensen, and Paul Norton of the National Renewable Energy Laboratory's Center for Buildings and Thermal Systems for their valuable technical contributions. In addition, the five Building America teams provided important new perspectives and critical assistance with the field tests and analytical studies cited in this report. We would also like to express our gratitude to George James, U.S. Department of Energy Program Manager for Building America, for the leadership and resources needed to complete this work. 


\section{Background}

The Building America program is an industry-driven research program sponsored by the U.S. Department of Energy (DOE) that applies systems engineering approaches to accelerate the development and adoption of advanced building energy technologies in new residential buildings. This program supports five building industry teams in the production of advanced residential buildings on a community scale. These teams use a systems engineering process to perform cost and performance assessments relative to each builder's standard practice, with the overall goal of reducing energy use without increasing the construction cost. The energy efficiency concepts incorporated in these houses are evaluated by conducting successive design, test, redesign, and retest iterations until cost and performance trade-offs yield innovations that can be cost-effectively used in production-scale housing.

The goals of the Building America program are to:

- Accelerate the use of advanced building energy systems in new residential construction through development and application of systems engineering approaches among cross-cutting industry teams.

- Develop innovative technologies and strategies that allow the U.S. housing industry to deliver environmentally sensitive, quality housing on a community scale while maintaining profitability and competitiveness of homebuilders and product suppliers.

- Reduce energy consumption for space heating and cooling in new houses built under the program by an average of $50 \%$, reduce construction site waste by $50 \%$, increase the use of recycled materials by $25 \%$, increase labor productivity, and reduce construction-cycle time.

- Generate additional energy savings through the use of energy efficient domestic hot water, lighting, appliances, and renewable energy sources.

To measure progress toward these goals, cost and performance trade-offs are evaluated through a series of controlled field and laboratory experiments supported by energy analysis techniques that use test data to "calibrate" energy simulation models. This report summarizes these energy analysis procedures, which are sufficiently flexible to meet the diverse objectives and characteristics of Building America projects around the United States. 


\section{Purpose}

As Building America has grown to include a large and diverse cross-section of the home building industry, accurate and consistent analysis techniques have become more important to help all program partners as they perform design trade-offs and calculate energy savings for prototype houses built as part of the program. There are many useful approaches and tools available to Building America teams and partners to calculate energy savings, and this document illustrates some of the analysis concepts proven effective and reliable for analyzing the transient energy usage of advanced energy systems as well as entire houses.

The analysis procedure described in this document provides a starting point for:

1. Calculating the energy savings of a prototype house relative to two important base cases: builder's standard practice and regional standard practice.

2. Using building simulation analysis to calculate annual energy savings based on side-by-side shortterm field testing of a prototype house and base-case house(s).

This document is divided into two sections. Section I provides general recommendations for prototype and base-case design assumptions, operating conditions, and analysis methodologies used to evaluate the performance of houses built under the Building America program. Many other valid techniques and definitions have been developed by other organizations and may be very useful to builders for specialized applications. For example, the HERS rating procedure must be followed to obtain an Energy Star certification. ${ }^{1}$ Also, it may be necessary to determine whether or not a prototype meets the International Energy Conservation Code (IECC) or Model Energy Code (MEC), which may apply if adopted by the state or local government. ${ }^{2}$

Section II presents guidelines for the effective hourly analysis of residential buildings using the DOE-2.2 building simulation tool. Although many of the suggestions were developed with Building America in mind, these guidelines are general enough to provide very useful techniques for comparing the energy performance of two similar houses in many other situations. The simulation concepts are very robust and can be beneficial to both novice and experienced DOE-2 modelers.

For the purpose of consistency, DOE-2 is recommended as the simulation program for Building America analysis. However, in cases where a house contains important features that cannot be accurately modeled with DOE-2, then any simulation program with hourly or shorter time steps may be used as long as it has passed the Building Energy Simulation Test (BESTEST) software testing procedure. Additional information about BESTEST can be found at www.eren.doe.gov/buildings/tools directory/software/bestest.htm.

There are also several examples in Appendix $\mathrm{C}$ at the end of this document that provide DOE-2 input files and analytical results from Building America projects.

\footnotetext{
${ }^{1}$ The Energy Star Rating is determined using the "National Home Energy Rating Technical Guidelines," National Association of State Energy Officials (NASEO), September 19, 1999. These guidelines are included as Appendix A of this report.

2 Summaries of the Model Energy Code and the Home Energy Rating System (HERS) Reference House are included in Appendix B. Additional information about these reference cases can be found at the U.S. Department of Energy Codes and Standards Web site (http://www.eren.doe.gov/buildings/codes_standards/buildings/) or the National Association of State Energy Officials Web site (http://www.natresnet.org/techguide/).
} 
It is anticipated that revised versions of this document will be required as the Building America teams gain experience using this approach and identify improvements that should be made to the procedure.

\section{Section I. General Performance Analysis Guidelines}

\section{Analysis Tools}

A key issue in any building energy analysis is the choice of the tool or program used to estimate energy consumption. An hourly simulation is often necessary to fully evaluate the time-dependent energy impacts of advanced systems used in Building America houses. Thermal mass, solar heat gain, and windinduced air infiltration are examples of time-dependent effects that can only be accurately modeled using a model that calculates heat transfer and temperature in short time intervals. In addition, an hourly simulation program is necessary to accurately estimate peak energy loads. Because of the large number of users, public availability, and level of technical support, DOE-2 is the hourly simulation tool recommended for systems analysis studies performed under the Building America program. Teams are also encouraged to use other simulation tools when appropriate for specialized building simulation analysis, provided the tool has met the requirements of BESTEST in accordance with the software certification sections of the RESNET/HERS Guidelines ${ }^{3}$. Regardless of the tool selected, teams should present complete results of the analysis, including annual heating and cooling energy (both source and site), peak hourly energy consumption, and cost-benefit calculations if available.

Section II presents guidelines and examples based on DOE-2.2, but the analysis process is relevant regardless of which simulation tool is being used. Example DOE-2 input files that define materials, systems, and boundary conditions consistent with regional construction practices were developed to speed analysis and reduce potential for input errors, and are included on the Building America web site at www.eren.doe.gov/buildings/building_america/performance_analysis.shtml. A full summary of building energy simulation tools can be found at www.eren.doe.gov/buildings/energy tools/. This web site also includes information about the new EnergyPlus tool sponsored by the DOE.

\section{Standard Assumptions Used for Definition of the Base-Case Designs}

Throughout the remainder of this document, the term "base case" refers to one of the following:

- Regional standard practice. This base case represents the house design that is most commonly built in the same geographic region as the prototype house. Energy savings relative to regional standard practice is an important measure of how a Building America prototype compares to similar houses currently being built in a particular market.

- Builder standard practice. This base case describes the house design that would have been built without the participation of the builder in the Building America program. It may be either an existing model in the builder's inventory, or a house similar to the prototype but with design features and construction techniques consistent with the builder's current inventory. A side-byside test combined with a calibrated hourly simulation provides the best comparison of a prototype with builder standard practice, but this situation is often not practical. Energy savings

\footnotetext{
3 “National Home Energy Rating Technical Guidelines," National Association of State Energy Officials (NASEO), September 19, 1999, p. 21.
} 
relative to builder standard practice provides a measure of the direct influence of Building America for a particular house.

The term "prototype" refers to a reengineered house with advanced systems and design features built for the first time as part of the Building America program.

\section{Regional Standard Practice}

Regional standard practice consists of those design specifications and construction techniques currently most common for new construction in a particular region of the country. This is very difficult to define with a high degree of confidence. Often, typical construction practices are similar to those required by applicable state or local energy codes. Some builders exceed these minimum requirements on a regular basis. Other builders consistently meet the minimum code requirements. As a result, an objective rule base that defines "true" regional standard practice is usually not realistic for the purpose of evaluating Building America prototype houses. Therefore, teams are strongly encouraged to perform a field survey to identify patterns in regional construction practices.

The following set of guidelines is based on the general approach taken by NREL engineers to quantify energy savings compared to regional standard practice, and is intended to serve as a practical starting point for analysis. If more accurate information is available from local surveys, this information should be used in place of the base-case definition provided below. It is strongly recommended that the teams provide documentation for alternate definitions.

Unless otherwise specified by local codes, regional standard practice is a hypothetical reference house that includes:

1. The same footprint and finished floor area as the prototype design.

2. The same ceiling heights and interior volume as the prototype design.

3. The same vertical fenestration area (including sliding glass doors) as the prototype design up to a maximum of $18 \%$ of floor area, distributed in the same orientation as the prototype. Alternatively, if the prototype house uses specific window area modifications to reduce heating and/or cooling loads as part of a broader bioclimatic strategy, ${ }^{4}$ then the regional standard practice house will use a total window area of $18 \%$ of the conditioned floor area, with the same proportion in each orientation as the prototype. The energy usage for the regional standard practice house will be calculated in each of the four cardinal orientations, and the average of these four cases will be used as the final energy usage for the base case.

4. No horizontal fenestration, defined as skylights or heat pipes oriented less than 45 degrees from a horizontal plane.

\footnotetext{
${ }^{4}$ A broader bioclimatic design strategy must include consideration of the orientation of houses within the community. If the prototype is a stand-alone house that is not the first in a series of production houses, then this requirement does not apply.
} 
5. The same amount of opaque external door area as the prototype design, distributed in the same orientation as the prototype design.

6. The same basic foundation type (slab, crawl space, or basement) as the prototype house.

7. A geographically appropriate foundation construction type, including dimensions and location of insulation and other construction materials consistent with regional standard practice. Basements will be considered fully conditioned in both the base case and prototype houses. If insulated crawl spaces are standard practice for the region, the crawl space will be modeled with wall insulation and no ceiling insulation; otherwise no insulation will be modeled in the base case.

8. A geographically appropriate exterior wall construction type, including materials and thickness of each layer, consistent with regional standard practice. A framing factor of $25 \%$ is assumed in the calculation of effective cavity insulation R-value.

9. A geographically appropriate glazing type consistent with regional standard practice.

10. The same door construction as in the prototype house.

11. A geographically appropriate roof construction type, including material and thickness of each layer, consistent with regional standard practice. A framing factor of $15 \%$ is assumed in the calculation of effective cavity insulation R-value.

12. A geographically appropriate floor construction type for the lowest floor, consistent with regional standard practice.

13. The same interior wall construction type as the prototype house. In cases where massive interior walls are used as part of a bioclimatic design strategy, the base case will have interior walls of lightweight construction, using the local standard for gypsum board and framing.

14. A geographically appropriate interior floor/ceiling construction type consistent with regional standard practice.

15. The same garage configuration, dimensions, and insulation as the prototype house.

16. The same site shading conditions that exist for the prototype. In cases where intentional site shading features are used as part of a bioclimatic design strategy, the base case will be modeled using site shading that is representative of regional standard practice.

17. The same levels of exterior shading from awnings, soffits, and other overhangs as the prototype house. Fixed exterior shading consistent with regional standard practice may be used for the base case if the prototype includes shading features specifically intended to reduce energy consumption as part of a broader bioclimatic design strategy.

18. Solar absorptivity for opaque areas of exterior walls equal to 0.50 , and solar absorptivity for opaque areas of roofs equal to 0.75 .

19. The same type of heating, cooling, and hot-water systems as the prototype, with the exceptions indicated in Table 1. 
20. The minimum National Appliance Energy Conservation Act (NAECA) efficiency in effect on January 1, 1992, for the same type of heating, cooling, and hot-water equipment used in the base case, as listed in Table 1. Part-load performance of space conditioning systems (air conditioners, heat pumps, furnaces, and air distribution) will be calculated using the methodologies described by the California Energy Commission in the 2001 Nonresidential ACM Approval Manual $^{5}$ :

Table 1. Base-case Heating, Cooling, and Hot-water System Efficiencies

\begin{tabular}{|c|l|l|}
\hline Function & Fuel/Device Used in Prototype House & Base-Case Device \\
\hline Heating & Gas Furnace & $78 \%$ AFUE Gas Furnace \\
& Oil Furnace & $78 \%$ AFUE Oil Furnace \\
& Electric Furnace & 6.8 HSPF Air-Source Heat Pump \\
& Air-Source Heat Pump (Split) & 6.8 HSPF Air-Source Heat Pump \\
& Air-Source Heat Pump (Package) & 6.6 HSPF Air-Source Heat Pump \\
& Gas Boiler (Water) & $80 \%$ AFUE Gas Boiler (Water) \\
& Gas Boiler (Steam) & $75 \%$ AFUE Gas Boiler (Water) \\
& Oil Boiler & $80 \%$ AFUE Oil Boiler \\
& Hot-water Combo System & 0.54 EF, 76\% Recovery Efficiency, \\
& & Natural-Gas, Hot-water Combo System \\
& Other Nonelectric Heating Source & with R-12 Tank Insulation \\
& Other Electric Heating Source & $78 \%$ AFUE Gas Furnace \\
\hline Cooling & Electric, Central Air Conditioner (Split) & 6.8 HSPF Air-Source Heat Pump \\
& Electric, Central Air Conditioner (Package) & 10 SEER Electric Air Conditioner \\
& Other Electric Air Conditioner & 9.7 SEER Electric Air Conditioner \\
& Other Cooling System & 10 SEER Electric Air Conditioner \\
& Gas Water Heater & 10 SEER Electric Air Conditioner \\
\hline Hot Water & Oil Water Heater & Gas (EF = 0.54) \\
& Electric Water Heater & Oil (EF = 0.51) \\
& Other & Electric (EF = 0.88) \\
& Gas (EF = 0.54) \\
\hline
\end{tabular}

Note: For acronyms and abbreviations listed above, please see the List of Terms on page vi.

21. Sizing of heating and cooling equipment determined according to Table 3, based on design loads calculated using an hourly simulation at the $99 \%$ American Society of Heating, Refrigerating and Air-Conditioning Engineers, Inc. (ASHRAE) winter and summer temperature extremes based on yearly temperature data (not seasonal). For cooling, design load includes both sensible and latent heat loads.

\footnotetext{
${ }^{5}$ California Energy Commission, “2001 Nonresidential ACM Approval Manual," Section 2.4.2., "Heating \& Cooling Equipment."
} 
22. An air handler with power consumption equal to $0.00055 \mathrm{~kW} / \mathrm{CFM}$, and sized to deliver ${ }^{6}$ :

a. For heating-only systems, CFM = Heating Capacity $(\mathrm{Btu} / \mathrm{hr}) / 60$.

b. For cooling-only or heating/cooling systems, CFM = Cooling Capacity (tons) $\bullet 400$.

23. Distribution system losses calculated using:

a) For forced air systems, an air loss fraction equal to $10 \%$ of the total flow rate. Conductive loss of the ducts will be calculated assuming R-5 duct insulation. Supply duct surface area shall equal $27 \%$ of the conditioned floor area, while return duct area shall equal $5 \%$ of conditioned floor area for one-story houses and $10 \%$ for two-story houses. Duct location shall be determined using the defaults in Table $2 .^{7}$

b) For hydronic systems, a heat loss rate calculated assuming R-5 pipe insulation and pipe surface area and location consistent with the prototype house.

Table 2. Duct Locations for Regional Standard Practice

\begin{tabular}{|c|c|c|c|c|}
\hline \multirow{2}{*}{$\begin{array}{c}\text { Prototype House Duct } \\
\text { Location }\end{array}$} & \multicolumn{2}{|c|}{ Supply Duct Location } & \multicolumn{2}{|c|}{ Return Duct Location } \\
\hline & One-Story & Two-Story & One-Story & Two-Story \\
\hline Attic/Dropped Ceiling & $100 \%$ Attic & $\begin{array}{c}65 \% \text { Attic, } 35 \% \\
\text { Conditioned Space }\end{array}$ & $100 \%$ Attic & $100 \%$ Attic \\
\hline Crawlspace & $100 \%$ Crawlspace & $\begin{array}{c}\text { 65\% Crawlspace, } 35 \% \\
\text { Conditioned Space }\end{array}$ & $100 \%$ Attic & $100 \%$ Attic \\
\hline Basement & $100 \%$ Basement & $\begin{array}{c}65 \% \text { Basement, } 35 \% \\
\text { Conditioned Space }\end{array}$ & $100 \%$ Basement & 100\% Basement \\
\hline Other & $100 \%$ Attic & $\begin{array}{c}65 \% \text { Attic, } 35 \% \\
\text { Conditioned Space }\end{array}$ & $100 \%$ Attic & $100 \%$ Attic \\
\hline
\end{tabular}

24. Annual average air-change rate equal to $0.35 \mathrm{ACH}$. Air-change calculations shall include the basement volume, which is assumed to be part of the conditioned space for the purpose of basecase comparisons.

25. No mechanical ventilation system beyond kitchen and bathroom exhaust fans.

26. Internal mass of furniture and contents equal to $8 \mathrm{lbs} / \mathrm{ft}^{2}$ of conditioned floor space. For solar distribution purposes, lightweight furniture covering $40 \%$ of the floor area shall be used for the input to DOE-2 or other hourly simulation tool that meets the requirements of BESTEST.

27. Internal and external thermal mass of walls, floors, and other structural elements consistent with the construction materials and dimensions used in the regional standard practice model.

\footnotetext{
${ }^{6}$ Simplification of Air Conditioning Contractors of America (ACCA) Manual S guidance.

${ }^{7}$ California Energy Commission, "Residential Manual for Compliance with California's 1998 Energy Efficiency Standards," Appendix 5.
} 
Table 3. Capacities of Base-case Heating and Cooling Systems

\begin{tabular}{|c|c|c|c|}
\hline Function & Base-Case Device & $\begin{array}{l}\text { Maximum Load }\left(\mathrm{L}_{\max }\right) \text { as } \\
\text { Predicted by DOE-2 }(\mathrm{Btu} / \mathrm{hr})\end{array}$ & Capacity \\
\hline \multirow[t]{5}{*}{ Heating } & Gas Furnace & $\begin{array}{l}\mathrm{L}_{\max }<32,000 \\
32,000<\mathrm{L}_{\max }<39,000 \\
39,000<\mathrm{L}_{\max }<48,000 \\
48,000<\mathrm{L}_{\max }<54,000 \\
54,000<\mathrm{L}_{\max }<60,000 \\
60,000<\mathrm{L}_{\max }<64,000 \\
64,000<\mathrm{L}_{\max }<72,000 \\
72,000<\mathrm{L}_{\max }<78,000 \\
78,000<\mathrm{L}_{\max }<98,000 \\
98,000<\mathrm{L}_{\max }<120,000 \\
\mathrm{~L}_{\max }>120,000\end{array}$ & $\begin{array}{l}40,000 \mathrm{Btu} / \mathrm{hr} \text { Input } \\
50,000 \mathrm{Btu} / \mathrm{hr} \text { Input } \\
60,000 \mathrm{Btu} / \mathrm{hr} \text { Input } \\
67,500 \mathrm{Btu} / \mathrm{hr} \text { Input } \\
75,000 \mathrm{Btu} / \mathrm{hr} \text { Input } \\
80,000 \mathrm{Btu} / \mathrm{hr} \text { Input } \\
92,000 \mathrm{Btu} / \mathrm{hr} \text { Input } \\
100,000 \mathrm{Btu} / \mathrm{hr} \text { Input } \\
125,000 \mathrm{Btu} / \mathrm{hr} \text { Input } \\
150,000 \mathrm{Btu} / \mathrm{hr} \text { Input } \\
\text { Add second furnace }\end{array}$ \\
\hline & Oil Furnace & $\begin{array}{l}\mathrm{L}_{\max }<55,000 \\
55,000<\mathrm{L}_{\max }<68,000 \\
68,000<\mathrm{L}_{\max }<85,000 \\
85,000<\mathrm{L}_{\max }<95,000 \\
95,000<\mathrm{L}_{\max }<112,000 \\
\mathrm{~L}_{\max }>112,000\end{array}$ & $\begin{array}{l}55,000 \mathrm{Btu} / \mathrm{hr} \text { Output } \\
68,000 \mathrm{Btu} / \mathrm{hr} \text { Output } \\
85,000 \mathrm{Btu} / \mathrm{hr} \text { Output } \\
95,000 \mathrm{Btu} / \mathrm{hr} \text { Output } \\
112,000 \mathrm{Btu} / \mathrm{hr} \text { Output } \\
\text { Add second furnace }\end{array}$ \\
\hline & Air-Source Heat Pump & All $\mathrm{L}_{\max }$ & $\begin{array}{l}\text { Use equations for cooling } \\
\text { capacity }\end{array}$ \\
\hline & Gas Boiler & $\begin{array}{l}\mathrm{L}_{\max }<42,000 \\
42,000<\mathrm{L}_{\max }<62,000 \\
62,000<\mathrm{L}_{\max }<81,000 \\
81,000<\mathrm{L}_{\max }<101,000 \\
101,000<\mathrm{L}_{\max }<122,000 \\
\mathrm{~L}_{\max }>122,000\end{array}$ & $\begin{array}{l}50,000 \mathrm{Btu} / \mathrm{hr} \text { Input } \\
75,000 \mathrm{Btu} / \mathrm{hr} \text { Input } \\
100,000 \mathrm{Btu} / \mathrm{hr} \text { Input } \\
125,000 \mathrm{Btu} / \mathrm{hr} \text { Input } \\
150,000 \mathrm{Btu} / \mathrm{hr} \text { Input } \\
\text { Add second boiler }\end{array}$ \\
\hline & Oil Boiler & $\begin{array}{l}\mathrm{L}_{\max }<68,000 \\
68,000<\mathrm{L}_{\max }<88,000 \\
88,000<\mathrm{L}_{\max }<98,000 \\
98,000<\mathrm{L}_{\max }<115,000 \\
115,000<\mathrm{L}_{\max }<145,000 \\
\mathrm{~L}_{\max }>145,000\end{array}$ & $\begin{array}{l}84,000 \mathrm{Btu} / \mathrm{hr} \text { Input } \\
105,000 \mathrm{Btu} / \mathrm{hr} \text { Input } \\
119,000 \mathrm{Btu} / \mathrm{hr} \text { Input } \\
140,000 \mathrm{Btu} / \mathrm{hr} \text { Input } \\
175,000 \mathrm{Btu} / \mathrm{hr} \text { Input } \\
\text { Add second boiler }\end{array}$ \\
\hline Cooling & $\begin{array}{l}\text { Any Air Conditioner, } \\
\text { Heat Pump, or Chiller }\end{array}$ & $\begin{array}{l}\mathrm{L}_{\max }<12,000 \\
12,000<\mathrm{L}_{\max }<18,000 \\
18,000<\mathrm{L}_{\max }<24,000 \\
24,000<\mathrm{L}_{\max }<30,000 \\
30,000<\mathrm{L}_{\max }<36,000 \\
36,000<\mathrm{L}_{\max }<42,000 \\
42,000<\mathrm{L}_{\max }<48,000 \\
\mathrm{~L}_{\max }>48,000\end{array}$ & $\begin{array}{l}1 \text { tons } \\
1.5 \text { tons } \\
2 \text { tons } \\
2.5 \text { tons } \\
3 \text { tons } \\
3.5 \text { tons } \\
4 \text { tons } \\
\text { Add second cooling unit }\end{array}$ \\
\hline Hot Water & $\begin{array}{l}\text { Gas } \\
\text { Oil } \\
\text { Electric } \\
\text { Other }\end{array}$ & $\begin{array}{l}\text { All } \mathrm{L}_{\max } \\
\text { All } \mathrm{L}_{\max } \\
\text { All } \mathrm{L}_{\max } \\
\text { All } \mathrm{L}_{\max }\end{array}$ & $\begin{array}{l}40 \text { gallons at } 140^{\circ} \mathrm{F} \\
40 \text { gallons at } 140^{\circ} \mathrm{F} \\
40 \text { gallons at } 140^{\circ} \mathrm{F} \\
40 \text { gallons at } 140^{\circ} \mathrm{F}\end{array}$ \\
\hline
\end{tabular}




\section{Builder Standard Practice}

Builder standard practice is defined as the current house design used by the builder partner. Builder standard practice may be either an existing model in the builder's current inventory, or it may be a hypothetical model if the prototype is a newly designed floor plan. If the prototype is based on an existing model, particularly if the analysis is part of a side-by-side evaluation, then the base case will have the specifications of that model. If the prototype is an original model, then the base case will have the specifications most commonly used by the builder in the same county or metropolitan area. Certain exceptions apply to these rules; however, as reflected in the following features of the base case:

1. The same footprint and finished floor area as the prototype design.

2. The same ceiling heights and interior volume as the prototype design.

3. The same vertical fenestration area (including sliding glass doors) as the prototype design up to a maximum of $18 \%$ of floor area, distributed in the same orientation. The energy usage for both the prototype and the builder standard practice house will be compared separately in each of the four cardinal orientations. Alternatively, if the prototype house uses specific window area modifications to reduce heating and/or cooling loads as part of a broader bioclimatic design strategy, then the builder standard practice house will use a total window area of $18 \%$ of the conditioned floor area, with the same proportion in each orientation as the prototype. Also in the case of a bioclimatic design strategy, the energy usage for the builder standard practice house will be calculated in each of the four cardinal orientations, and the average of these four cases will be used as the final energy usage for the base case. However, if the standard window area and distribution can be reasonably established for the local builder, it should be incorporated into the builder's standard practice model instead of the window areas and distributions referenced above.

4. No horizontal fenestration, defined as skylights or heat pipes oriented less than 45 degrees from a horizontal plane.

5. The same amount of opaque external door area as the prototype design, distributed in the same orientation as the prototype design.

6. The same basic foundation type (slab, crawl space, or basement) as the prototype house. Alternatively, a foundation consistent with the builder's standard practice may be used if the prototype includes a change to the basic foundation type that is specifically intended to reduce heating and cooling energy consumption.

7. A fully conditioned basement if the prototype includes a basement.

8. The same interior wall construction type as the prototype house. In the case where massive interior walls are used as part of a bioclimatic design strategy, the interior walls will have a construction type consistent with builder standard practice.

9. The same site shading conditions that exist for the prototype. In cases where intentional site shading features are used as part of a bioclimatic design strategy, the base case will be modeled using site shading that is representative of builder or regional standard practice. 
10. The same levels of exterior shading from awnings, soffits, and other overhangs as the prototype house. Fixed exterior shading consistent with the builder's standard practice may be used if the prototype includes shading features specifically intended to reduce energy consumption as part of a broader bioclimatic design strategy.

11. Distribution system losses calculated using:

a) For forced air systems, an air loss fraction equal to $10 \%$ of the total flow rate. Conductive loss of the ducts will be calculated assuming duct insulation and duct surface area consistent with builder standard practice.

b) For hydronic systems, a heat loss rate calculated assuming pipe insulation and pipe surface area and location consistent with builder standard practice.

12. Annual average air-change rate equal to $0.35 \mathrm{ACH}$, unless test results for a statistically significant sample of the builder's standard construction houses clearly demonstrate annual average air exchange rates higher than $0.35 \mathrm{ACH}$. If measured infiltration is lower than $0.35 \mathrm{ACH}$, then a value of $0.35 \mathrm{ACH}$ will be used. This assumes that occupants will use window openings when necessary to supply a total of $0.35 \mathrm{ACH}$ outdoor air exchange. ACH calculations shall include the basement volume, which is assumed to be part of the conditioned space in all situations.

13. Internal mass of furniture and contents equal to $8 \mathrm{lbs} / \mathrm{ft}^{2}$ of conditioned floor space. For solar distribution purposes, lightweight furniture covering $40 \%$ of the floor area shall be used for the input to DOE-2 or other hourly simulation tool that meets the requirements of BESTEST. 


\section{Standard Assumptions Used for Definition of the Prototype House}

1. Annual average air-change rate equal to $0.35 \mathrm{ACH}$ resulting from natural infiltration and controlled ventilation combined, unless test results for the prototype house indicate an annual average air exchange rate higher than $0.35 \mathrm{ACH}$. If measured infiltration is lower than $0.35 \mathrm{ACH}$, then a value of $0.35 \mathrm{ACH}$ will be used. This assumes that occupants will use window openings when necessary to supply a total of $0.35 \mathrm{ACH}$ outdoor air exchange.

2. Basements will be considered fully conditioned.

3. The actual site shading conditions.

4. Internal mass of furniture and contents equal to $8 \mathrm{lbs} / \mathrm{ft}^{2}$ of conditioned floor space. For solar distribution purposes, lightweight furniture covering $40 \%$ of the floor area shall be used for the DOE-2 input.

5. All other parameters for the prototype house will be based on measured data or final design specifications.

\section{Operating Conditions}

The following operating conditions and other assumptions shall apply to both the prototype house and the three base cases defined in this document. These operating conditions are based on the cumulative experience of the authors through their work on Building America and other residential energy efficiency programs.

1. Thermostat set points for cooling: $78^{\circ} \mathrm{F}$

Thermostat set points for heating: $68^{\circ} \mathrm{F}$

2. Typical schedules for opening and closing windows and shades vary greatly with climate, house orientation, and occupant behavior. For the purpose of modeling the prototype and base-case houses, draperies are assumed to be drawn over half of the windows all of the time. An equivalent interpretation could be that all of the windows have their curtains drawn half of the time. In either case, each window has a shading multiplier and a conduction multiplier. The drawn curtains are assumed to decrease the solar gain by $40 \%$ and add approximately an R- 0.5 to the fenestration. Screens are assumed to be present on half of the windows as well, and the combined dirt and screen is assumed to decrease solar gains by $10 \%$. The natural ventilation schedule in DOE-2 is set to reflect windows being opened occasionally. The ventilation temperature schedule is set to a constant $68^{\circ} \mathrm{F}$, forcing the windows closed if the indoor temperature falls below this value. In situations where there is a cooling load, the outdoor temperature is below the indoor temperature, and the window is not already open, the probability of the window being opened is set at a constant $50 \%$. 
3. Total internal sensible heat gain from lights, people, and equipment varies with the size of the prototype house. Typical equipment intensity is calculated using Equation 1:

\section{Equation 1: Equipment load $\left(\mathrm{Btu} / \mathrm{day} / \mathrm{ft}^{2}\right)=\left[\right.$ House area $\left(\mathrm{ft}^{2}\right) \times 12.5\left(\mathrm{Btu} / \mathrm{day} / \mathrm{ft}^{2}\right)+15,000$ $\left(\right.$ Btu/day)] / House area $\left(\mathbf{f t}^{2}\right)$}

Smaller loads may be used for lighting in the prototype house if the light fixtures contain ballasts that only function with energy efficient bulbs, or for home appliances (e.g., dishwashers and refrigerators) if the appliances are included as standard equipment by the builder.

Because the equipment heat gains may vary by space (i.e., bedrooms and nonbedrooms) and time of day, separate schedules should be created that reflect realistic occupancy patterns. However, the total daily heat gain due to this component should still equal the calculated equipment load. The profile in Table 4 represents a typical internal gain schedule for residential buildings.

Table 4. Typical Internal Gain Schedule

\begin{tabular}{|c|c|c|c|}
\hline Hour of Day & \% Total Load & Hour of Day & \% Total Load \\
\hline 1 & 1.8 & 13 & 4.9 \\
\hline 2 & 1.5 & 14 & 3.1 \\
\hline 3 & 1.4 & 15 & 2.9 \\
\hline 4 & 1.4 & 16 & 3.2 \\
\hline 5 & 1.4 & 17 & 6.4 \\
\hline 6 & 2.0 & 18 & 7.1 \\
\hline 7 & 3.4 & 19 & 6.6 \\
\hline 8 & 6.5 & 20 & 5.1 \\
\hline 9 & 6.2 & 21 & 4.9 \\
\hline 10 & 6.7 & 22 & 5.5 \\
\hline 11 & 6.6 & 23 & 4.2 \\
\hline 12 & 5.0 & 24 & 2.1 \\
\hline
\end{tabular}

Sensible heat gain from each person is $210 \mathrm{Btu} / \mathrm{hr}$ and latent heat gain is $140 \mathrm{Btu} / \mathrm{hr}$. The total number of people living in a typical house is assumed to be equal to the number of bedrooms plus one. An appropriate occupancy schedule should be developed to calculate total heat gains from people on an hourly basis.

4. Estimated hot-water usage based on Equation 2.

\section{Equation 2: Gallons/day $=30$ gallons $+(10$ gallons $x$ number of bedrooms $)$}

5. Weather data shall be based on typical meteorological year (TMY2) data from $1961-1990^{8}$ or equivalent data for the location most similar in climate.

\footnotetext{
${ }^{8}$ Analytic Studies Division, National Renewable Energy Laboratory (http://rredc.nrel.gov/solar/old_data/ nsrdb/tmy2/).
} 


\section{Comparing a Prototype House to a Base Case}

The process of evaluating Building America house performance involves the comparison of energy use between a base case and a Building America design. Energy savings are typically calculated by comparing the total annual heating and cooling energy for each house. Only energy derived from fossil fuel, nuclear, or hydropower sources shall be considered; contributions from site-generated renewable energy will be excluded from the calculation of total energy consumption.

To calculate energy usage for a prototype house and either the regional standard practice or builder standard practice base case, the following equation is used. Energy usage for the prototype should always be calculated in each of the four cardinal orientations, plus any other orientations that may be expected as part of the community layout. Energy units shall be in Btus and source energy will be the basis for comparison. Energy conversion factors for propane and fuel oil assume that the source energy multipliers are close to unity. ${ }^{9}$

\section{Equations 3 \& 4:}

Total annual heating/ cooling energy usage (Btu)

Total annual home energy usage (Btu)
$=$ Annual electric heating and cooling energy $(\mathrm{kWh}) \cdot 3412 \cdot \mathrm{M}_{\mathrm{e}}$ + Annual gas heating and cooling energy (therms) $\bullet 100,000 \bullet \mathrm{M}_{\mathrm{g}}$

+ Annual propane heating and cooling energy (gallons) • 91,080

+ Annual fuel oil heating and cooling energy (gallons) • 138,400

$=$ Annual electric energy for all applications $(\mathrm{kWh}) \cdot 3412 \cdot \mathrm{M}_{\mathrm{e}}$ + Annual gas energy for all applications (therms) $\bullet 100,000 \bullet \mathrm{M}_{\mathrm{g}}$

+ Annual propane energy for all applications (gallons) • 91,080

+ Annual fuel oil energy for all applications (gallons) • 138,400

Where: $\quad \mathrm{M}_{\mathrm{e}}=3.57=$ Site to source multiplier for electricity.

$\mathrm{M}_{\mathrm{g}}=1.02=$ Site to source multiplier for natural gas $^{10}$.

To calculate percent energy savings for a prototype house compared to either the regional standard practice or builder standard practice base case, the following equation is used. As previously mentioned, the energy usage of the regional standard practice base case will be the average of the energy usage in each of the four cardinal orientations.

\section{Equation 5:}

$\%$ Annual energy savings
$=($ Annual source energy usage for base case - Annual source energy usage for prototype) / Annual source energy usage for base case

\footnotetext{
${ }^{9}$ California Title 24, Section 6, "Energy Efficiency Standards for Residential and Nonresidential Buildings," Publication Number: P400-98-001, July 1999.

${ }^{10}$ Energy Information Administration, U.S. Department of Energy, "Measuring Energy Efficiency in the United States Economy: A Beginning," Chapter 7, October 1995.
} 
Peak hourly energy consumption is calculated in a similar manner, and is based on the hour with the greatest gas or electric energy consumption during the course of one year as determined by the hourly simulation

\section{Important Differences Among Base-case Definitions}

Because each of the base cases has a unique purpose in the analysis of Building America prototype houses, there are important differences in how elements of each base case are defined. Table 5 provides a summary of "blind" and "neutral" features of each of the two base-case definitions, along with the Energy Star Reference Home. Blind features are the same for both the prototype and base case, indicating that the feature is an important fundamental feature of the house, and its specifications are usually driven by demands unrelated to energy usage, such as architectural appeal, functionality, or comfort. Neutral features are fixed at a level consistent with regional or builder standard practice, and energy savings resulting from changes to this level are recognized for the prototype house. An individual feature may be marked as both neutral and blind in situations where bioclimatic design intent must be considered. If the design change is made for bioclimatic design reasons, the feature is neutral. If the design change is motivated by architectural or other purposes, the feature is blind.

Table 6 presents similar information, only from the standpoint of common design measures used in Building America prototypes. In the table, "yes" indicates that the design measure leads to a change in energy usage (either positive or negative) for the prototype compared to the relevant base case. For example, unvented attics are not recognized as energy-saving measures when using the Energy Star Reference Home, and fuel switching is only allowed when using Builder Standard Practice as the base case. 
Table 5. Summary of Neutral and Blind Features of the Base Cases

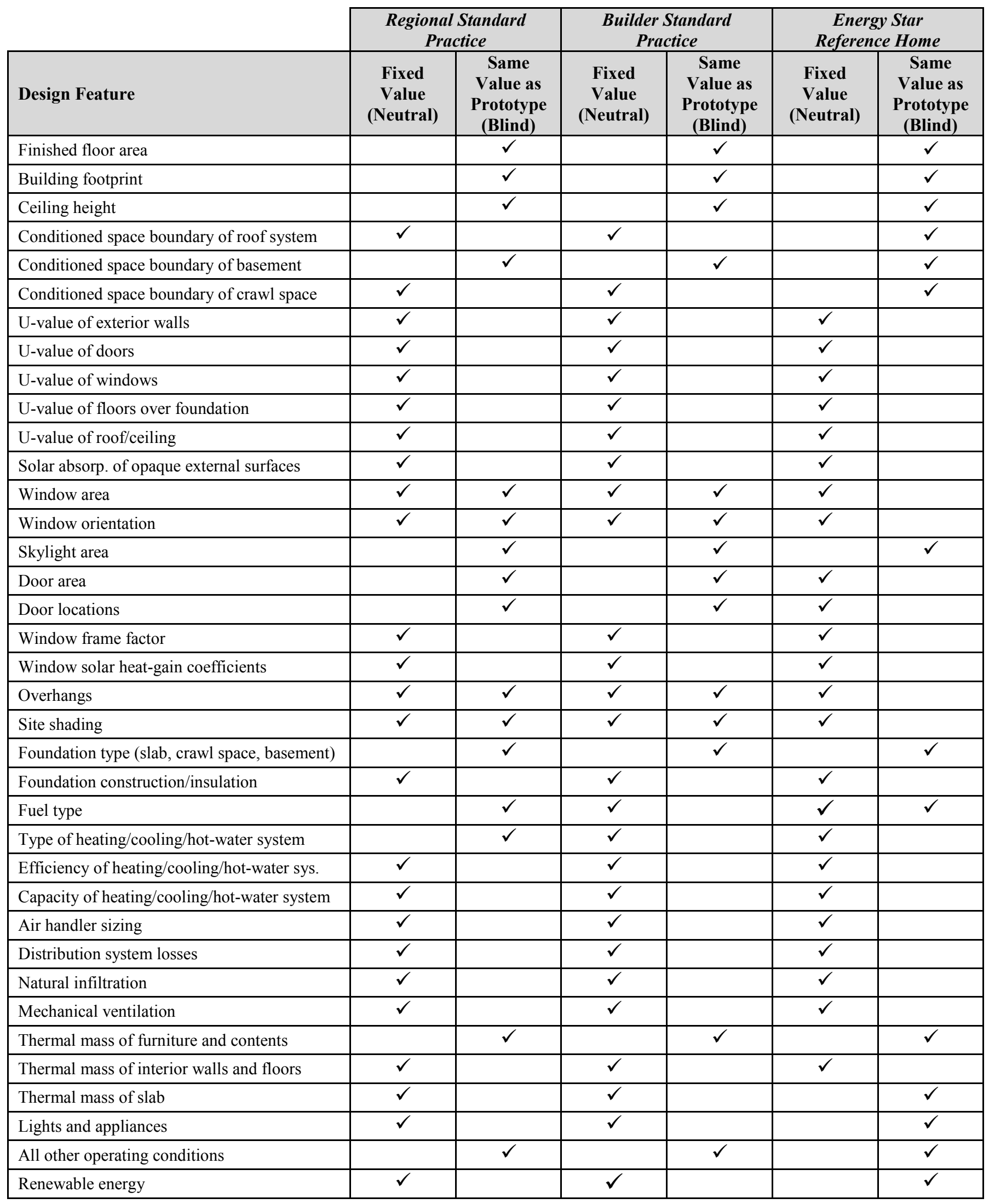


Table 6. Common Building America Design Changes and Resulting Effect on Energy Usage ${ }^{11}$

\begin{tabular}{|c|c|c|c|}
\hline Design change & $\begin{array}{c}\text { Regional Standard } \\
\text { Practice }\end{array}$ & $\begin{array}{c}\text { Builder Standard } \\
\text { Practice } \\
\end{array}$ & $\begin{array}{c}\text { Energy Star } \\
\text { Reference Home }\end{array}$ \\
\hline Advanced framing & Yes & Yes & Yes \\
\hline Move ducts into conditioned space & Yes & Yes & Yes \\
\hline Shorten ducts & Yes & Yes & Yes \\
\hline Improve sealing and insulation of ducts & Yes & Yes & Yes \\
\hline Reduce air infiltration to $0.35 \mathrm{ACH}$ & Yes & Yes & Yes \\
\hline Reduce air infiltration below $0.35 \mathrm{ACH}$ & No & No & Yes \\
\hline $\begin{array}{l}\text { Improve space heating, space cooling, or } \\
\text { water heating efficiency }\end{array}$ & Yes & Yes & Yes \\
\hline Fuel switching & No & Yes & No \\
\hline Combo water/space heater & No & Yes & Yes \\
\hline Improve attic/wall/window insulation & Yes & Yes & Yes \\
\hline Unvented attic or crawl space & Yes & Yes & No \\
\hline Conditioned basement & No & No & No \\
\hline $\begin{array}{l}\text { Improve basement/crawl space/slab } \\
\text { insulation }\end{array}$ & Yes & Yes & Yes \\
\hline Low-e, spectrally selective windows & Yes & Yes & Yes \\
\hline Bioclimatic & Yes & Yes & Yes \\
\hline Architectural changes & No & No & Yes \\
\hline Site-generated renewable energy & Yes & Yes & Yes \\
\hline Programmable thermostat & No & No & Yes \\
\hline Downsize air handler fan & Yes & Yes & Yes \\
\hline Add mechanical ventilation & Yes & Yes & Yes \\
\hline Energy efficient lights and appliances & Yes & Yes & No \\
\hline
\end{tabular}

\footnotetext{
${ }^{11}$ Assumes change relative to builder's existing model. "Yes" indicates that the measure results in a change to the total energy consumption. "No" indicates that energy consumption is unchanged by the measure.
} 


\section{Section II. Residential Energy Modeling Approach}

\section{Overview}

This section offers a set of guidelines for creating the simulation models needed for the analysis of Building America prototype house designs, sets forth a clear methodology for conducting the analysis, and presents a format for reporting the results. These guidelines and the examples presented are based on the National Renewable Energy Laboratory's (NREL) analysis of past and current Building America projects. While the framework for the Building America analysis is presented here, it is the responsibility of each analyst to use this framework in the most appropriate way for each project. The tools and techniques described in this report are powerful, flexible, and rather than limiting an analyst's options, can give the analyst important insight into the building physics and lead to even more creative and effective designs.

The modeling efforts associated with the Building America project are intended to quantify the energy savings of a wide variety of efficiency measures. For this reason, Building America energy simulations, as compared to many other residential energy simulations, require a relatively high level of detail in the building shell, building operation, and equipment performance.

As described in Section I, the base-case building definitions for each Building America house have the same building geometry as the improved case. The regional standard practice building uses standard assumptions for building construction materials and heating, ventilating, and airconditioning (HVAC) performance. These assumptions may vary from region to region and are intended to represent typical construction practices in nearby housing developments. The builder's standard practice model represents the house that the builder would have built had they not participated in the Building America program. Often, the builder's standard practice is more energy efficient than regional standard practice, but it may occasionally be less efficient. The Building America prototype house has efficiency levels as designed by the Building America team. Savings are determined by comparing the energy use of the Building America prototype to that of the base case.

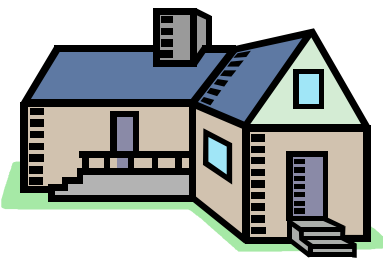

Regional Standard Practice

Wall insulation: R-11/+0

Ceiling insulation: R-30

Air-conditioning SEER: 10

Heating AFUE: 78

Windows: Clear glass
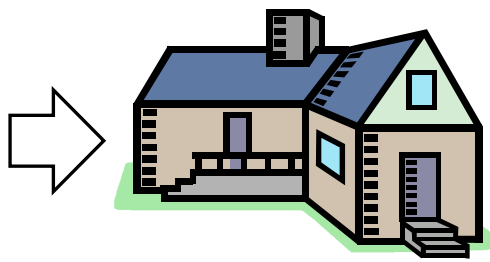

\section{Builder's Standard Practice}

Wall insulation: R-11/+5

Ceiling insulation: R-30

Air-conditioning SEER: 10

Heating AFUE: 78

Windows: Low-e glass

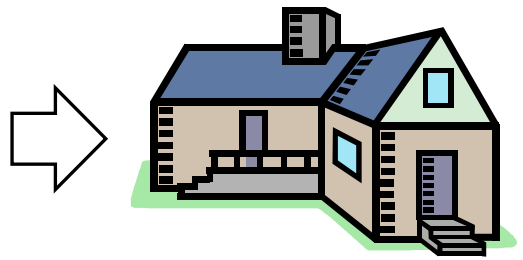

\section{Building America Prototype}

Wall insulation: R-11/+5

Ceiling insulation: R-38

Air-conditioning SEER: 12 Heating AFUE: 90

Windows: Low-e, spectrally selective glass

Figure 1. Comparison of prototype and base-case house features 
Familiarity with the DOE-2 building energy simulation program is needed to create the simulation models required for this analysis. While the examples and sample files included with this report provide a quick start to creating the models with DOE-2.2, building energy simulation requires experience and a background in building thermodynamics, HVAC systems, and, to some degree, computer programming. For those familiar with the DOE-2.1 program, the changes and new features found in the DOE-2.2 program are described in the "DOE-2.2 Basics Manual."

\section{DOE-2 Building Energy Simulation Program}

DOE-2 is an hourly building energy simulation tool appropriate for building designers and energy researchers. The program has been developed over the past 25 years by DOE laboratories and by private companies. The program has been continuously upgraded to keep pace with new system types and better algorithms, and has been established as one of the benchmark energy simulation tools in common use.

In its standard format, the DOE-2 program resembles a highly specialized computer programming language. The building and its energy systems are described using a hierarchical series of commands and keywords listed in a text file. User-defined variables along with simple math and logic functions can be used within the context of the building description. This format allows great flexibility when creating the building simulation model, but also requires significant effort and expertise from the user.

The latest version of the DOE-2 building energy simulation program is DOE-2.2. Both DOE-2.2 and its predecessor DOE-2.1E are available for a nominal fee from J. J. Hirsch and Associates. Information on the programs and how to obtain them can be found on the Internet at http://www.doe2.com. DOE-2.2 is available in a variety of formats: DOS executable, DOS-32bit executable, and a Dynamic Linked Library (DLL) version with a simple Windows interface. A compact disc with all of these versions of DOE-2, along with hundreds of weather files for U.S. locations, is available for the cost of shipping and handling.

For DOE-2.2, the text file written by the user that describes the simulation model is first compiled by a stand-alone program called DOEBDL.exe. This program checks the format of the model description, alerts the user to any errors in the model, and even cautions users about possible mistakes in modeling techniques. A second program, DOESIM.exe, then runs the actual hourly simulation of the building thermodynamics. Detailed results are available for almost all aspects of the building simulation, and summary reports provide a quick look at the building's energy performance.

Documentation for the DOE-2.2 program comes as a set of Adobe Acrobat PDF files. The manuals are organized into three sections: DOE-2.2 Basics, DOE-2.2 Dictionary, and DOE-2.2 Topics. The help files that accompany other DOE-2.2 based programs, such as eQUEST or PowerDOE, can also be used as references.

The energy simulation research community is also currently developing an advanced analysis program called EnergyPlus that is currently available as a beta test version at the DOE web site (http://www.eren.doe.gov/buildings/energy_tools/energyplus/). 


\title{
Analysis Approach
}

The analysis approach covered by this document is quite simple. The typical heating and cooling annual energy use of a new building design is compared to a base-case building of the same basic description, only without the improved features. Site energy use, energy costs, and source energy use are all used to compare the buildings. Energy use for heating hot water may be included in these calculations.

Standard building operation is established in this document and is used for all of the simulation analysis. The base-case building characteristics are also described in this document, although these characteristics are somewhat flexible and are allowed to change, based on the local building practice. The intent of the base case is to describe the typical building that is commonly built in the same geographic area as the prototype. Also of interest is the house that the builder would have built in the absence of the Building America program.

The three benchmark simulation models that have historically been created for NREL's Building America analysis - regional standard practice, builder standard practice, and the prototype - are all built around the same Building Description Language (BDL) input file. Once the regional standard practice model is established, incremental changes in the model specifications lead to the other models. The following model descriptions are an example of this process:

\author{
Regional Standard Practice Model \\ - $\quad 1,500-\mathrm{ft}^{2}$, single-story house \\ - R-11 cavity-filled walls \\ - Double-pane clear windows with aluminum frames \\ - R-30 ceiling insulation \\ - No crawl-space insulation \\ - $\quad$ Natural infiltration $=0.35 \mathrm{ACH}$ \\ - Seasonal energy efficient ratio (SEER) 10, 2.5-ton air conditioner \\ - Annual fuel utilization efficiency (AFUE) 78 furnace \\ - Standard duct loss to attic
}

Increment 1: Change to double-pane, low-e windows with vinyl frames

Increment 2: Add crawl-space wall insulation of R-10 (builder's standard practice)

Increment 3: Lower duct loss by placement within conditioned space

Increment 4: Improve air conditioner to SEER 12

Increment 5: Improved heating system to AFUE 94

Increment 6: Natural infiltration lowered to $0.15 \mathrm{ACH}$ (to illustrate energy effects of ventilation)

Increment 7: Increase infiltration to $0.35 \mathrm{ACH}$ via mechanical ventilation

\section{(Building America prototype)}

In this case, the Building America prototype is modeled by changing the regional standard practice model in seven increments. The builder's standard practice house is modeled by changing two components of the regional standard practice model - the window type and the crawl-space insulation. 


\section{Modeling Process}

The process of creating a series of energy simulation models using DOE-2 can take many paths. For some projects, detailed hourly data from short-term testing may be available; for other projects, little more than schematic design data will be available. The process described here is merely an outline, the details of which will be unique to each project.

The major steps in the modeling process are identified below and described in the following sections.

1. Thermal zoning. Identify the separate thermal zones for the model based on the floor plan and HVAC design of the Building America prototype building.

2. Floor plan take-off. Use the prototype floor plans to create the basic layout of the building, using DOE-2.2's polygon features.

3. Building shell take-off. Use the prototype construction documents to quantify individual window areas, door areas, wall areas, roof areas, etc.

4. Building constructions. Use the prototype construction documents to create constructions for windows, doors, walls, roof, and underground surfaces.

5. Shading surface take-off. Use construction documents and site information to identify building and site shading.

6. Energy efficiency measure design. Create DOE-2 macros for each variable of each component that will change from the base case to the prototype case.

7. Base-case definition. Use this document, as well as knowledge of local building practice, to define the base-case characteristics.

8. Base case to prototype. Translate the design improvements to DOE-2 BDL code in the simulation model to incrementally change the base-case model to the prototype design.

9. DOE-2 simulation and design verification. Use the DOE-2 simulation results to verify both the simulation model and building design.

10. Energy efficiency measure analysis and reporting results. Use the results of all the DOE2 simulations to analyze each component of the building improvements.

\section{Thermal Zoning}

An important consideration when creating residential energy models is the number of separate thermal zones that will be modeled. For some studies, a simple residence modeled as a single zone is adequate to assess overall loads or overall changes in loads. However, when a simulation includes the performance of actual HVAC systems, most residences need multiple zones to capture the thermodynamic diversity that occurs both when the systems are on and off.

The maximum number of conditioned zones appropriate to model is a function of the floor plan and the HVAC system layout for a house. Another important consideration is the type of questions that the simulation model is expected to answer. Unless the model is also being used to help design supply airflow rates to each register, well-connected spaces and spaces that are

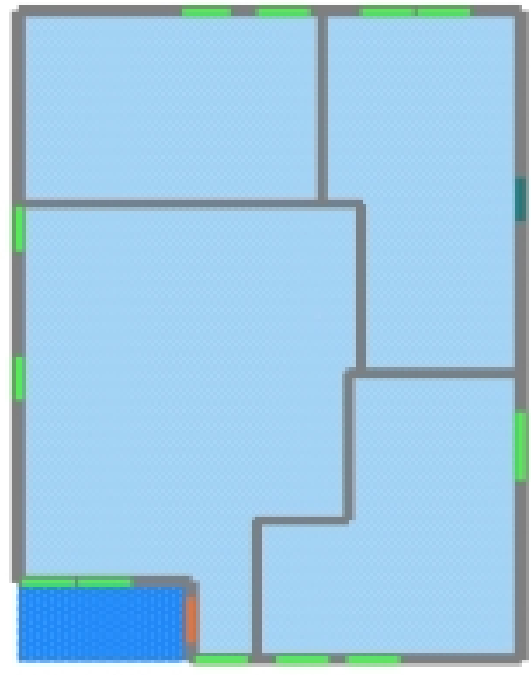

Figure 2. Example house floor plan containing four spaces. (Image capture from eQUEST.) 
thermodynamically similar can be, and should be, combined into single zones. This is especially true of the zone that contains the thermostat. The thermostat zone should be well-connected to the spaces around it so that it properly responds to the changing conditions of the space.

A typical single-story house might have four or five conditioned zones. Two-story houses might have eight or nine conditioned zones. Houses that use passive solar heating may also require additional zones. When possible, thermally well-connected spaces should be modeled as single zones.

Unconditioned areas that are closely coupled with conditioned spaces, such as closets and bathrooms, should be combined with a nearby space. Garages, crawl spaces, basements, and unconditioned spaces more closely coupled with the outdoor conditions than the indoor conditions (such as enclosed porches) should be modeled as separate unconditioned spaces.

\section{Floor Plan Take-offs}

The key to modeling the building geometry of a residence lies in properly describing the building floor plans. The floor plans are described using a new feature of DOE-2.2, called polygons. Polygons can be used to describe the layout of spaces and floors, and are also used to describe any irregularly shaped wall or shading surface. For the residential models, they are especially useful to describe the floor plan of the house and each individual zone.

"You define polygons by specifying the coordinates of the vertices an $x-y$ coordinate system that is local to the polygon. You can then position this local polygon coordinate system in the parent coordinate system by setting appropriate values for $\mathrm{X}, \mathrm{Y}, \mathrm{Z}$, Azimuth and Tilt of the wall, space or floor. You must specify the vertices in counter-clockwise order, as seen when you face the polygon." (DOE-2.2 Help File)

An example of a simple (rectangular) polygon in BDL:

$\begin{array}{clll}\text { KitchenPoly } & =\text { POLYGON } & \\ \text { V1 } & =(0,35) \\ \text { V2 } & =(19,35) \\ \text { V3 } & =(19,49.8) \\ \text { V4 } & =(0,49.8)\end{array}$

In this case, the origin of the polygon is located far from its vertices. As a shortcut when creating the polygons, the 19-ft x 14.8-ft rectangle shares the origin with the house polygon.

The advantage of using polygons to describe the floor plans is especially evident when entering the required data for exterior walls. Instead of specifying the $\mathrm{X}$ and $\mathrm{Y}$ coordinates of the wall, along with the height, the width, and the azimuth, a vertex of the polygon needs to be assigned to the wall.

An example of an exterior wall specification when polygons are used:

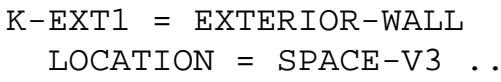

This command places a wall between the third and fourth vertices of the space polygon. The wall height will default to the space height of the floor. 
Polygons should be created for each floor of the house. These floor polygons will include all spaces on the floor, including conditioned and unconditioned spaces. An attached garage, for example, should be included in the first-floor polygon. Additionally, space polygons should be created for each space that will be a separate zone in the DOE-2 model.

Placement of separate internal and external walls should be considered when creating the space polygons. In the figure to the right, the "Great Room" polygon could be defined using four vertices. However, because six separate walls will be defined for this floor plan (three internal and three external), the polygon used to describe the space should be defined with the six vertices

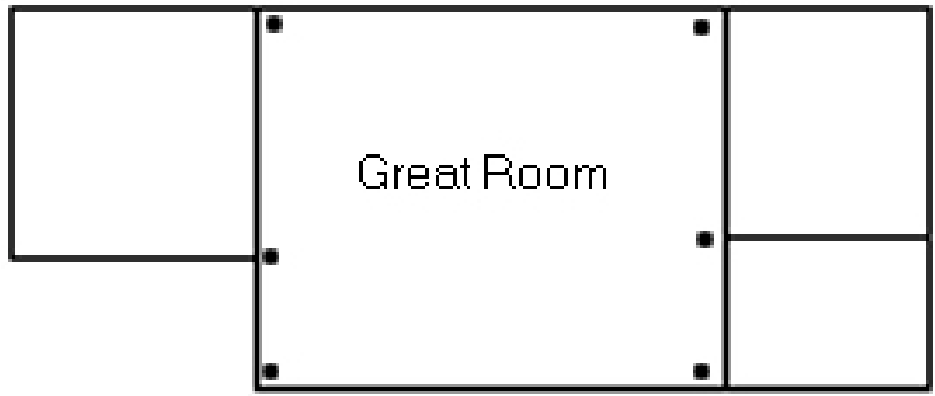

Figure 3. Definition of vertices for typical floor plan shown.

\section{Building Shell Take-offs}

The building shell take-offs involve identifying the location and size of all windows, doors, interior walls, exterior walls, and underground walls. As seen above, placement of exterior walls is simplified when polygons are used to describe the floor plan (using the LOCATION keyword under the EXTERIOR-WALL command).

Placement of doors and windows is accomplished by specifying the $\mathrm{X}$ and $\mathrm{Y}$ coordinates within the appropriate exterior wall. Placement of the windows is especially important so building and site shading is properly accounted for. Below is an example of a window specification.

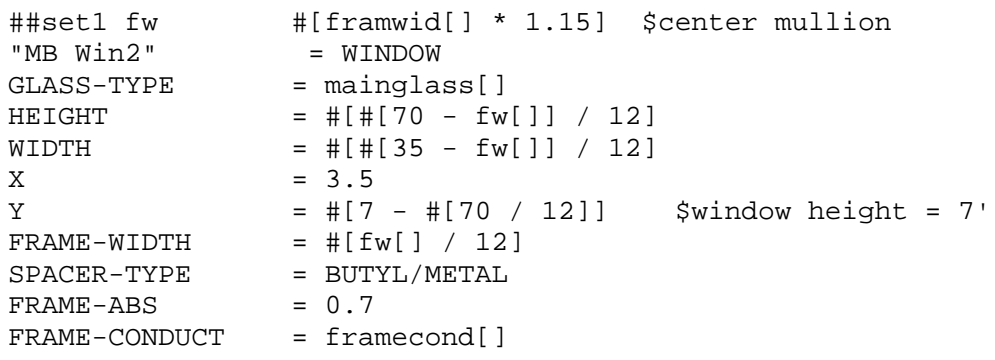

In this case, the window was measured as $70 \mathrm{in.} \mathrm{high} \mathrm{by} 35 \mathrm{in}$. wide, including the frame. Macros are used for the frame width, the glass type, and the frame conductivity because these values might change from the base case to the prototype. The $\mathrm{X}$ value places the window $3.5 \mathrm{ft}$ from the left side of the preceding wall definition. The $\mathrm{Y}$ value places the top of the window $7 \mathrm{ft}$ from the bottom of the wall. 
Doors containing a significant amount of glazing should be separated into an opaque area (specified using the DOOR command) and a window area. Sliding glass doors are treated as windows.

To capture the correct surface orientations of roof surfaces and attic end walls, trapezoidal and triangular polygons are often needed. The figure below shows a three-dimensional representation of a DOE-2.2 model with fairly accurate roof geometry. The roof is

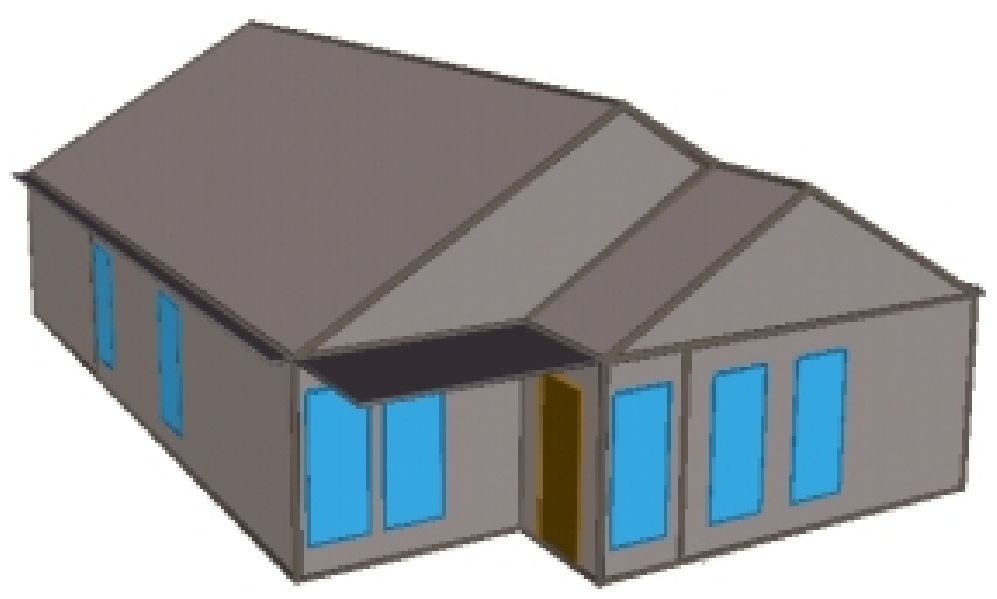

Figure 4. Building geometry of a simple residence. (Image captured from eQUEST.) composed of six polygons, all part of the attic space.

\section{Building Constructions}

Wall Constructions. There are a number of ways to model wall constructions within the DOE-2 program. Quick Walls have no mass and are capable of steady-state heat transfer only. For the purposes of Building America, these types of walls are used only for lightweight door constructions, such as garage doors. Massive walls, built up from descriptions of the individual material components, provide a much more accurate model of heat transfer.

The following BDL code is an example of how to define an exterior wall with the proper mass and overall thermal resistance. The first section defines the properties of the wall cavity; the next section uses macros to determine the net R-value and density of the cavity. A conglomerate material, representing the combination of insulation and framing, is then defined and the wall is "put together" using the LAYERS and CONSTRUCTION commands.

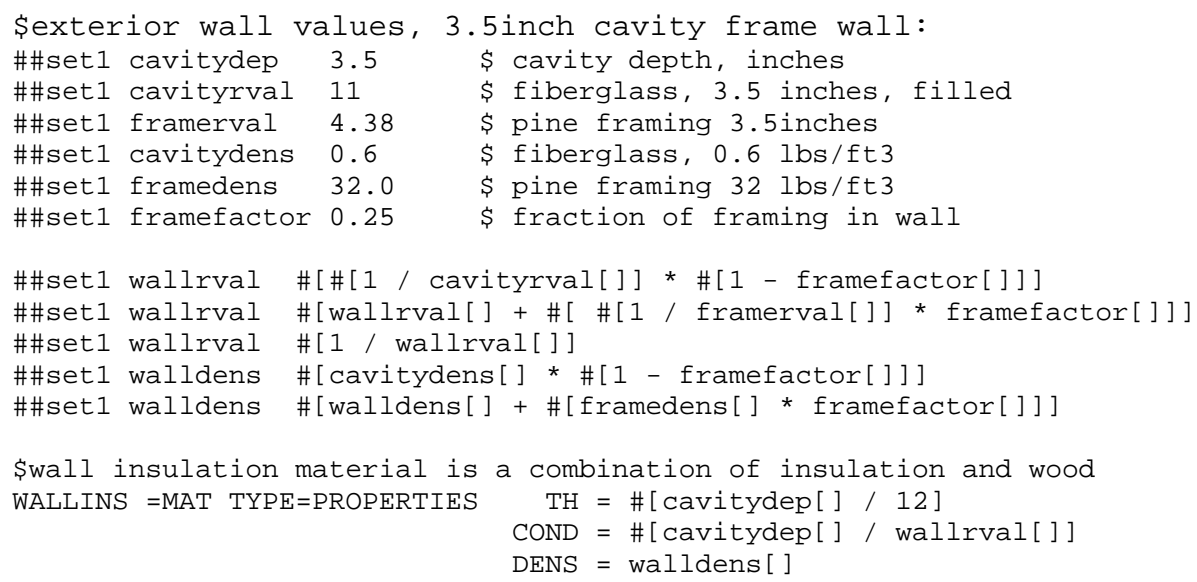




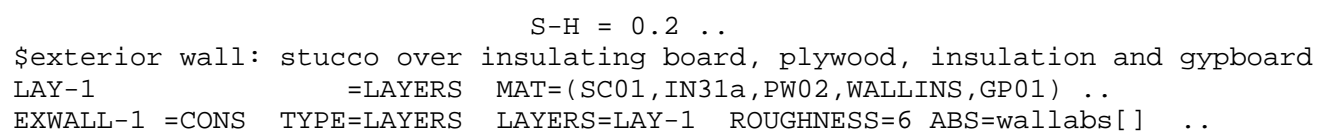

This type of conglomerate wall construction makes it possible to use polygons to place exterior wall sections. An alternative method of describing frame walls is to create separate wall types for the cavity and framing section. In this latter case, rather complicated polygons need to be specified for each floor plan, or the traditional $\mathrm{X}$ and $\mathrm{Y}$ coordinate system needs to be used to place exterior walls.

Foundations. There are a number of ways to model the heat flow through foundation walls connected to the underground. When possible, the method described by Fred Winkelman ${ }^{12}$ should be used. This perimeter heat-loss method uses predetermined conduction factors that relate the heat loss rate of an underground surface to the exposed perimeter of the surface as well as the construction and insulation levels. The method applies to slab-on-grade floors, basement walls, and crawl-space walls. (This article is found on pages 10-17 of the "User News Articles.PDF" file.)

It is very important not to model underground surfaces using the standard DOE-2 construction command combined with a standard underground wall command. Though this may seem reasonable, the model assumes a constant ground temperature (versus a ground temperature that is influenced by the building heat loss), and losses can be greatly overpredicted.

Slab-on-Grade Floors. The perimeter heat-loss method requires that a separate slab construction be defined for each space that has a slab floor. Each construction includes a fictitious insulating layer based on the area, exposed perimeter, and construction of the slab. The following BDL code defines the slab floor construction for one space:

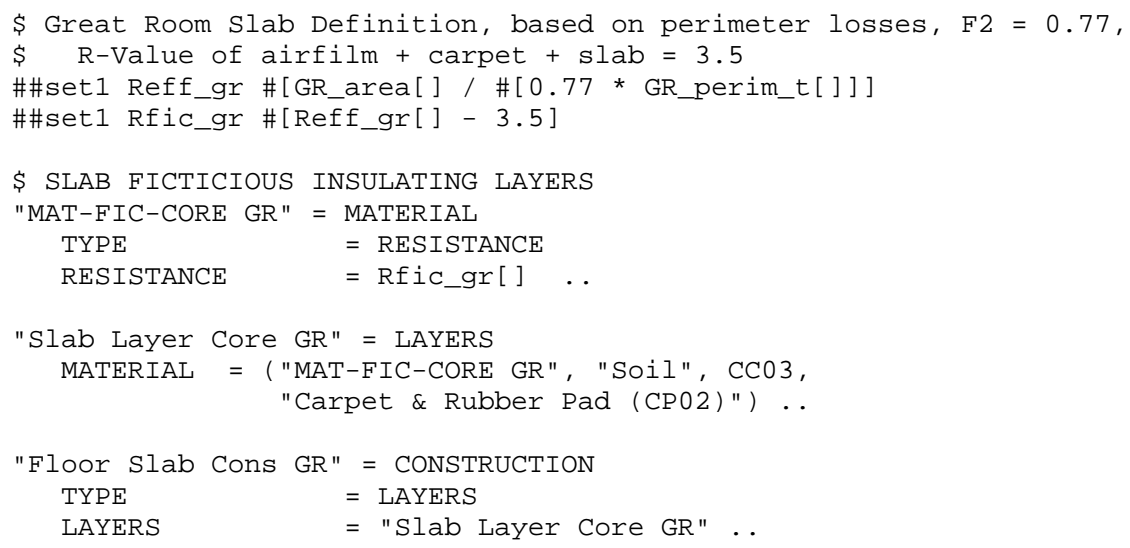

With the soil properties defined as:

SOIL $=$ MAT TYPE=PROPERTIES TH=2.0 COND=1.0 DENS=115 $\mathrm{S}-\mathrm{H}=0.26 \ldots$

\footnotetext{
${ }^{12}$ Winkelman, F. Building Energy Simulation User News, Vol. 19, No. 1 (Spring 1998).
} 
This construction, as well as the effective R-value of the slab (Reff_gr) is referenced when defining the slab floor as an underground wall within the space command.

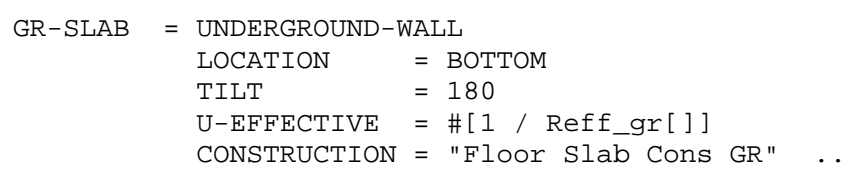

Craw spaces and Basements. Crawl-space and basement walls are modeled in much the same way as slab floors, with the location specified by a polygon vertex. Floors for basements and crawl spaces are described in a similar fashion using DOE-2, only the "R-eff" is set to a high value and the U-effective is set to zero. For a more detailed description, see the complete text of the Winkelman article.

Windows. Windows are always specified using the DOE-2.2 window library, either using the standard glazing types listed in Appendix F of the DOE-2.2 Basics documentation or using custom glazing types created using the Window 4.1 program. Custom glazing types can be added to the user library in the EXENT subdirectory under the main DOE-2.2 installation directory.

\section{Shading}

Shading has been found to be an important consideration when evaluating fenestration measures, even as important as the glazing type. Shading can be caused by a variety of sources, all of which should be properly accounted for.

Site Shading. Shading caused by nearby buildings, fences, and vegetation falls under this category. This type of shading is modeled using the BDL Building-Shade command. A transmittance value can also be added if vegetation partially shades the house.

$$
\begin{array}{lll}
\text { BUILDING-SHADE } & \mathrm{X}=40 & \mathrm{Y}=55 \quad \mathrm{Z}=0 \\
\text { \$right bldg\$ } & \mathrm{H}=13 & \mathrm{~W}=55
\end{array}
$$

(Note: Site shading will normally be fixed at typical levels for the purpose of comparing prototype and base-case houses.)

Overhangs/Self-Shading. Roof overhangs can be modeled as separate BUILDING-SHADE commands or as an exterior wall that is part of the attic space. It is usually much simpler to model the overhang as a building shade, as in the example below:

$\begin{array}{llll}\text { BUILDING-SHADE } & \mathrm{X}=0 & \mathrm{Y}=50 & \mathrm{Z}=\text { =wallht [] } \\ \text { \$left soffit } & \mathrm{H}=1 & \mathrm{~W}=44 & \\ & \mathrm{AZ}=270 & \text { TILT=180 } & \ldots\end{array}$

The height where the shading surface begins, the $\mathrm{Z}$ coordinate, is specified using the user-specified macro for the house wall height. The location of shading surfaces relative to the house should be checked using eQUEST or PowerDOE, as misplaced shading surfaces can have a large impact on the heating and cooling loads. 
Walls of the building that can possibly shade other surfaces can be specified as shading surfaces by adding the SHADING-SURFACE = YES keyword to the EXTERIOR-WALL command.

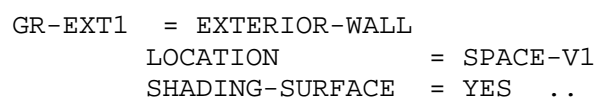

The modeler can cause all exterior walls to become shading surfaces by using the SET-DEFAULT command for EXTERIOR-WALL, but this unnecessarily slows down the simulation time.

\section{Measure Design}

This step involves assessing how the prototype model differs from the base-case model and determining how to best incorporate all of the changes. Macros, as either single variables or entire sets of BDL commands and keywords, are established for each incremental change.

The types of measures and BDL modifications that are identified in this step will help determine how the modeling details of the base building will take shape.

\section{Defining the Base Case}

As previously discussed, the base-case models are created from the construction documents for the prototype building using the guidelines set forth in Section I.

Cooling Equipment Performance/Sizing. Sizing and performance of the base-case cooling equipment were outlined in Tables 1 and 3 of this document. The SEER will be translated to energy efficiency ratio (EER) as outlined for California's Title $24^{13}$ :

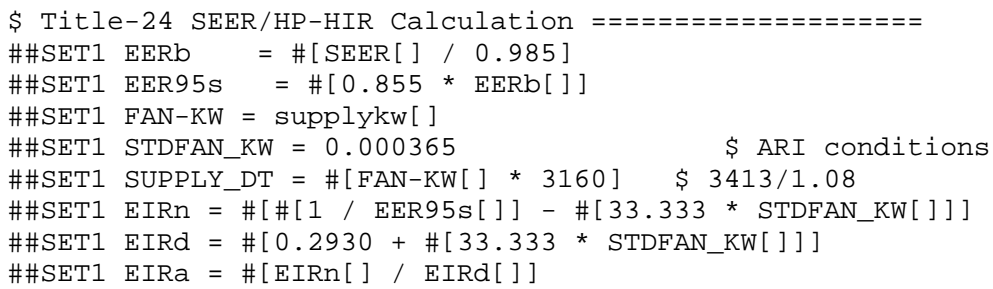

The "supplykw" value will be set to $0.00055 \mathrm{~kW} / \mathrm{CFM}$. This value is typical of a number of Building America test houses, including both base-case and prototype houses. At a minimum, the following cooling equipment parameters will be specified under the SYSTEM command:

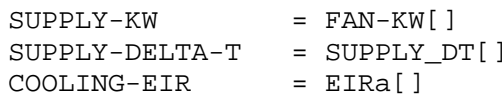

${ }^{13}$ California Energy Commission, "1998 Alternative Calculation Method Approval Manual," Section 2.4.2.7, "Cooling Efficiency of DOE Covered Air Conditioners." 
Heating Equipment Performance/Sizing. As described in Section I, heating equipment representing regional standard practice will be a furnace with an AFUE of 78 if the main heating fuel for the prototype is natural gas. If the main heating fuel is electricity, the heating equipment will be an air-source heat pump with an heating seasonal performance factor (HSPF) of 6.8. The heat pump will be sized based on the cooling capacity and will have electric resistance backup. Supply fan power will be the same as described for the cooling equipment.

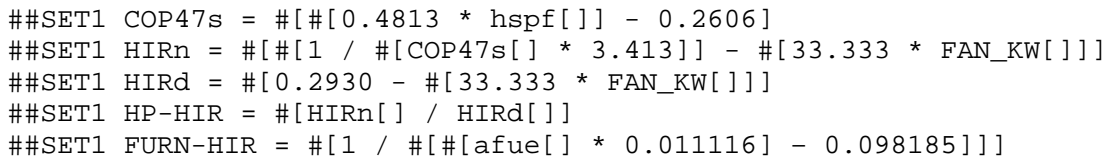

Water Heating Equipment Performance. Because the typical efficiency specification of hot-water systems is the energy factor, which accounts for annual average burner efficiency and tank losses, the domestic hot water (DHW) model in DOE-2 is very nearly disabled in favor of the simplified algorithm: Energy $(\mathrm{Btu})=$ Hot-water Load $(\mathrm{Btu}) / \mathrm{EF}$. The hot-water volume is determined as $30+10 \cdot$ [number of bedrooms] gallons per day, and the set point is $140^{\circ} \mathrm{F}$. The DOE-2 part-load performance curve for DHW equipment must be overridden with a curve that eliminates any efficiency dependency on partial loads, and tank losses must be set to zero. The entire DOE-2 DHW model is shown below:

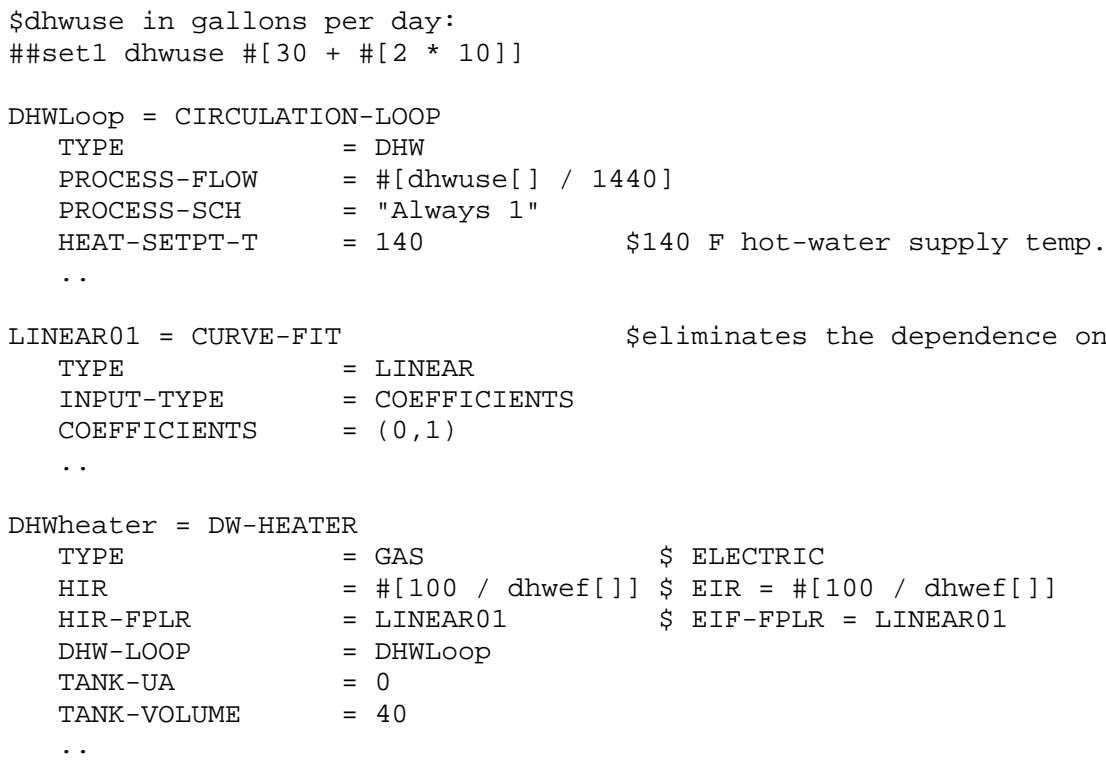

\section{From Regional Standard Practice to Prototype}

Once the regional standard practice building is modeled, the prototype building is created by changing the characteristics of each component that differs between the base case and prototype. In the interest of quality control and of assessing each measure's value, the incremental changes are added progressively and one at a time. Each component improvement is analyzed by simulating the new combination of measures and comparing the energy performance to the previous combination of measures. 
The order of the measures is left up to the analyst. However, proper consideration should be given to a measure's benefit-to-cost $(\mathrm{B} / \mathrm{C})$ ratio. Measures with the highest $\mathrm{B} / \mathrm{C}$ ratio should be added to the base building first. Measures for which savings are highly sensitive to the order in which they are added to the base building should be identified and explored further.

As an example of measures that can be highly sensitive to the order in which they are added to the base building, consider a hypothetical unvented-roof measure and a duct improvement measure. To make for an even more interesting analysis, the duct improvement measure, which lowers the air-loss rate to the attic from $15 \%$ to $3 \%$, has approximately the same added cost as the unvented roof strategy, which moves the insulation from the attic floor to the attic roof.

If the unvented attic measure is added first, the following results are possible:

Table 7. Scenario 1: Unvented Attic Analyzed First

\begin{tabular}{|c|c|c|c|c|c|c|c|c|}
\hline \multirow{2}{*}{$\begin{array}{l}\text { Measure } \\
\text { Description }\end{array}$} & \multirow{2}{*}{$\begin{array}{c}\text { Htg/Clg } \\
\text { (kWh) }\end{array}$} & \multirow{2}{*}{$\begin{array}{c}\text { Heating } \\
\text { (therms) }\end{array}$} & \multirow{2}{*}{$\begin{array}{l}\mathrm{Htg} / \mathrm{Clg} \\
\text { Cost } \\
(\$ / y r)\end{array}$} & \multirow{2}{*}{$\begin{array}{c}\text { Measure } \\
\text { Value } \\
\text { (\$/yr) }\end{array}$} & \multirow{2}{*}{$\begin{array}{c}\text { Package } \\
\text { Savings } \\
\text { (\$/yr) }\end{array}$} & \multirow{2}{*}{$\begin{array}{c}\text { Cost } \\
\text { Savings }\end{array}$} & \multicolumn{2}{|c|}{ Source Energy } \\
\hline & & & & & & & kBtu & Savings \\
\hline Base case & 3000 & 600 & 600 & $\mathrm{~N} / \mathrm{A}$ & $\mathrm{N} / \mathrm{A}$ & $\mathrm{N} / \mathrm{A}$ & 9715 & N/A \\
\hline Unvented attic & 2500 & 590 & 554 & 46.0 & 46 & $8 \%$ & 8202 & $16 \%$ \\
\hline Duct improvement & 2438 & 575 & 540 & 13.7 & 60 & $10 \%$ & 7999 & $18 \%$ \\
\hline
\end{tabular}

Under Scenario 1, the unvented attic measure has a savings of $\$ 46$ per year, much higher than the duct improvement savings of less than $\$ 14$ per year. The $\mathrm{B} / \mathrm{C}$ ratio is higher for the unvented attic measure, and therefore should come first, according to this analysis. When the measure order is reversed, the results in Scenario 2 are possible.

Table 8. Scenario 2: Duct Improvement Analyzed First

\begin{tabular}{|c|c|c|c|c|c|c|c|c|}
\hline \multirow{2}{*}{$\begin{array}{l}\text { Measure } \\
\text { Description }\end{array}$} & \multirow{2}{*}{$\begin{array}{c}\mathrm{Htg} / \mathrm{Clg} \\
\text { (kWh) }\end{array}$} & \multirow{2}{*}{$\begin{array}{l}\text { Heating } \\
\text { (therms) }\end{array}$} & \multirow{2}{*}{$\begin{array}{c}\text { Htg/Clg } \\
\text { Cost } \\
(\$ / y r) \\
\end{array}$} & \multirow{2}{*}{$\begin{array}{c}\text { Measure } \\
\text { Value } \\
\text { (\$/yr) } \\
\end{array}$} & \multirow{2}{*}{$\begin{array}{c}\text { Package } \\
\text { Savings } \\
\text { (\$/yr) }\end{array}$} & \multirow{2}{*}{$\begin{array}{c}\text { Cost } \\
\text { Savings }\end{array}$} & \multicolumn{2}{|c|}{ Source Energy } \\
\hline & & & & & & & kBtu & Savings \\
\hline Base case & 3000 & 600 & 600 & $\mathrm{~N} / \mathrm{A}$ & $\mathrm{N} / \mathrm{A}$ & N/A & 9715 & N/A \\
\hline Duct improvement & 2666 & 533 & 533 & 66.8 & 67 & $11 \%$ & 8633 & $11 \%$ \\
\hline Unvented attic & 2438 & 575 & 540 & -7.1 & 60 & $10 \%$ & 7999 & $18 \%$ \\
\hline
\end{tabular}

When measures are highly interactive, it is important to explore the sensitivity of the savings to the order of the measures, and results should be presented in multiple sequences to illustrate this sensitivity and clarify the $\mathrm{B} / \mathrm{C}$ analysis.

One convenient way of modeling the incremental changes from the base case to the prototype is to use macros that progressively add in measures as the value of an "EEM level" variable increases. The following BDL code is used in the sample input file:

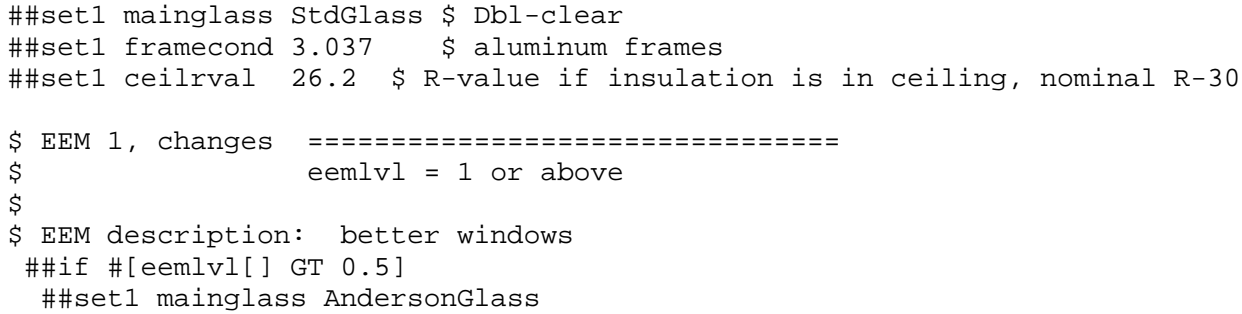




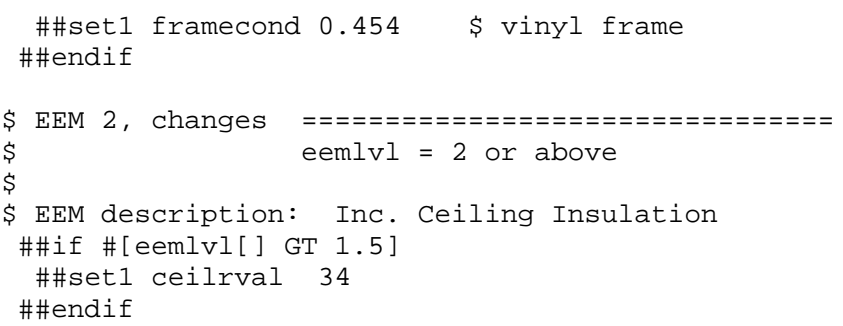

If the value of the "eemlvl" macro is zero, then the changes associated with "EEM 1" and "EEM 2" are skipped. As the value of "eemlvl" increases, more and more components are changed to reflect the prototype building design.

\section{DOE-2 simulation and design verification}

The results of the base-case and prototype simulations need to be examined carefully to ensure that the building systems are well-designed and that the buildings are modeled as intended.

Input Verification. The importance of verifying that the inputs to the model are as intended cannot be overstated. Given the flexible nature of the inputs, the use of macros to calculate many of the input values and the potential complexity of the building geometry, opportunities abound for misplaced walls and misplaced decimal points.

The easiest way to verify the building geometry is to import the BDL input file into one of the DOE2.2-based simulation tools discussed at the end of this report. These tools will show all of the building surfaces in a three-dimensional format. Misplaced or incorrectly sized surfaces are quickly identified.

DOE-2 produces a series of verification reports that summarize and list all of the important inputs for a surface, a space, or the whole building. Reports LV-B and LV-C (listed in Appendix B) are particularly useful to verify building construction inputs. Report LV-B should be examined to verify the area and volume of each defined space. Report SV-A (also listed in Appendix B) summarizes the major system characteristics. Supply airflow rates to each space are listed as is the total heating and cooling capacity of the systems.

It is also useful to examine the component loads of the various building components using a report like LS-C. This report shows the peak load associated with each major building component. Errors in the simulation model are often caught by comparing the peak component heat flows with the analyst's expectations.

Performance Verification. Another important quality control effort is to ensure that the HVAC systems are performing as intended. Probably the best indicator of this is the comfort level maintained in the house. Report SS-K reports the monthly average temperatures during cooling, heating, and floating hours. SS-R reports the part-load operation of the equipment and how many hours any particular zone was underheated or undercooled. The temperature profile in each zone can be quickly assessed with the SS-O reports for each zone. (Time saver: searching for the word "below" within the DOE-2 output file will quickly take you to the bottom of each temperature profile.) For many residential systems, it is not unusual for some of the zones to float past the control temperature, even fairly often. Because the thermostat is in only one zone (typically), the other zone temperatures will float until the zone with the thermostat calls for heating or cooling. If some zones 
are almost always too hot or cold, it could indicate that the zone with the thermostat is not properly "connected" with the spaces around it or that the supply airflow to the zones is not well designed.

\section{Analysis and Reporting of Results}

Consistent reporting of the analysis is important for proper and timely interpretation of the results. The example table below (Table 9) shows the minimum required data for a building analysis. A description of the building and system characteristics for the starting point and for each increment in the analysis should accompany the table.

Table 9 is for a sample analysis that includes DHW improvements. Any special conditions applied to the analysis should be clearly stated in the table header. Builder's standard practice (BSP) should be identified as a separate run if it differs from the regional standard practice (RSP) base case.

Table 9. Sample Homes Simulation Analysis (with DHW); Front Faces North (as-is), Supplemental Ventilation Off

\begin{tabular}{|c|c|c|c|c|c|c|c|c|}
\hline \multirow{3}{*}{ Description } & \multicolumn{8}{|c|}{ Space Conditioning and DHW } \\
\hline & \multirow{2}{*}{$\begin{array}{c}\mathrm{Htg} / \mathrm{Clg} \\
(\mathrm{kWh})\end{array}$} & \multirow{2}{*}{$\begin{array}{l}\text { Heating } \\
\text { (therms) }\end{array}$} & \multirow{2}{*}{$\begin{array}{c}\mathrm{Htg} / \mathrm{Clg} \\
\text { Cost } \\
(\$ / \mathrm{yr}) \\
\end{array}$} & \multirow{2}{*}{\begin{tabular}{|c|} 
Measure \\
Value \\
$(\$ / y r)$ \\
\end{tabular}} & \multirow{2}{*}{$\begin{array}{c}\text { Package } \\
\text { Savings } \\
\text { (\$/yr) }\end{array}$} & \multirow{2}{*}{\begin{tabular}{|c|} 
Cost \\
Savings
\end{tabular}} & \multicolumn{2}{|c|}{ Source Energy } \\
\hline & & & & & & & kBtu & Savings \\
\hline RSP Base & 5225 & 190 & $\$ 461$ & & & & 75910 & \\
\hline $\begin{array}{l}\text { Base + SEER12 } \\
\text { (BSP Base) }\end{array}$ & 4404 & 190 & $\$ 403$ & 57.47 & $\$ 57$ & $12 \%$ & 67495 & $11 \%$ \\
\hline Base + Imp. Ducts & 3526 & 182 & $\$ 338$ & 65.48 & $\$ 123$ & $27 \%$ & 57552 & $24 \%$ \\
\hline Base ++ Increased Infiltration & 3658 & 200 & $\$ 356$ & -18.23 & $\$ 105$ & $23 \%$ & 61021 & $20 \%$ \\
\hline Base ++ Imp. Windows & 3055 & 179 & $\$ 303$ & 34.49 & $\$ 157$ & $34 \%$ & 52369 & $31 \%$ \\
\hline Base ++ Increased Ceiling Ins. & 2969 & 174 & $\$ 295$ & 8.55 & $\$ 166$ & $36 \%$ & 50896 & $33 \%$ \\
\hline Base ++ 2-ton Cap. & 2944 & 174 & $\$ 293$ & 1.74 & $\$ 168$ & $36 \%$ & 50641 & $33 \%$ \\
\hline Base ++ DHW EF & 2944 & 160 & $\$ 286$ & 7.00 & $\$ 175$ & $38 \%$ & 48994 & $35 \%$ \\
\hline $\begin{array}{l}\text { Base ++ Ventilation } \\
\text { (BA Proto) }\end{array}$ & 4113 & 178 & $\$ 377$ & -90.82 & $\$ 84$ & $18 \%$ & 63092 & $17 \%$ \\
\hline Proto + AFUE 94 & 4113 & 170 & $\$ 373$ & 4.00 & $\$ 88$ & $19 \%$ & 62151 & $18 \%$ \\
\hline
\end{tabular}

Descriptions of the table headers follow:

$\mathbf{H t g} / \mathbf{C l g}(\mathbf{k W h})$. The total site electricity use of the space heating and cooling systems and hot-water heating system, if applicable. This value includes auxiliaries such as hot-water circulation pumps for space heating, supply air fans, etc. Electricity use of circulation pumps for domestic hot water should not be included unless circulation pumps are needed for a Building America efficiency measure.

Electricity use for other purposes, such as heated outdoor pools, outdoor spas, and snowmelt, should not be included in this value.

Heating (therms). The total site heating energy use of gas space and water heating equipment. Standby losses should be included. Heating energy use for other purposes, such as cooking or pools, should not be included. 
Htg/Clg Cost (\$/yr). The cost of energy associated with the previous two columns. The average energy costs are represented in dollars per therm and dollars per $\mathrm{kWh}$, and should be clearly stated in the text of the report.

Measure Value (\$/yr). The savings in dollars per year of the current measure. This is determined as the heating/cooling cost for the current measure minus the heating/cooling cost for the previous increment. The measure value can be highly sensitive to the order in which the measures are analyzed.

Package Savings (\$/yr). The total savings in dollars per year for the current package of measures. This is determined as the heating/cooling cost for the current measure minus the heating/cooling cost for the Building America base run.

Cost Savings (\%). Calculated as the package savings for this measure divided by the heating and cooling cost of the base case and multiplied by 100 to convert to percentage.

Source kBtu. Source kBtu is calculated as the (kWh for heating and cooling) $3.412(\mathrm{kBtu} / \mathrm{kWh}) /$ (electric source-to-site efficiency) + (total therms of heating and cooling) $100(\mathrm{kBtu} /$ therm $) /$ (gas source-to-site efficiency). Use an electric source-to-site efficiency of 0.28 and a gas source-to-site efficiency of 0.98. (See footnote 7.)

$$
\mathrm{kBtu}_{\mathrm{src}}=\frac{\mathrm{kWh} \cdot 3.412}{0.28}+\frac{\text { therms } \cdot 100}{0.98}
$$

Source Savings (\%). The percent reduction in source energy.

$$
\text { Source Savings }(\%)=\frac{\text { Source }_{\text {base }}-\text { Source }_{\text {current }}}{\text { Source }_{\text {base }}} \cdot 100
$$

Additional data for each increment may be of interest, and should be supplied in a spreadsheet:

- Separate cooling $\mathrm{kWh}$ and heating $\mathrm{kWh}$ (if applicable)

- Supply fan kWh during cooling

- Supply fan kWh during heating

- Hours zones are undercooled

The process of extracting results for the DOE-2.2 simulation file for the series of runs required for the Building America analysis can be made quite simply using the BA-Run22 program supplied with this report. This program is discussed in detail in the Support Programs section of this report.

\section{Modeling Topics}

There is almost never just one way to model any particular thermal component of an energy simulation exercise. Varying levels of detail are usually available, and the greatest level of detail is not always the most appropriate choice. Efforts should be directed towards those areas that most influence the final answers. The following sections present methods for modeling infiltration, unvented attics, and HVAC systems. These discussions are based on experience with past projects and should be considered a starting point for further research and refinement. 


\section{Infiltration}

Infiltration of outdoor air into a house is caused by a number of mechanisms - occupant behavior (opening doors and windows), natural infiltration caused by wind and the temperature difference between the house and the outdoors, mechanical ventilation of bathrooms and kitchens, and the infiltration caused by HVAC operation. The latter mechanism may be intentional or caused by leaks from supply ducts into unconditioned spaces.

Each of these mechanisms should be considered when creating the simulation model. There are a number of ways to model infiltration in DOE-2. Some of these methods and their common application in the Building America context are described below.

Infiltration Caused by Occupant Behavior. There are at least two aspects of infiltration caused by occupant behavior. The more predictable aspect is when occupants open windows, and possibly doors, because there is a perceived cooling load and the outdoor temperature is cooler than the indoor temperature. In DOE-2 BDL, this is called natural ventilation. This is not an unusual situation, especially in desert climates where evening temperatures, even in the middle of the cooling season, may drop well below $70^{\circ} \mathrm{F}$.

The DOE-2 simulation program accounts for this type of infiltration by allowing for a specific and additional amount of air exchange based on the hourly indoor and outdoor temperature, the estimated air-exchange rate when the windows are open, and the probability that an occupant will open the windows if they are closed. The modeler must also consider other aspects of the local climate when modeling this type of infiltration. It may be impractical to open windows even during cool evenings if it is windy and dry (i.e., dusty).

An example of the BDL code under the SYSTEM command used to specify natural ventilation is:

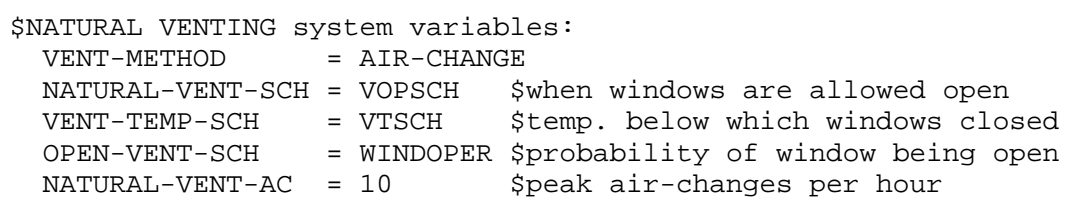

The natural vent schedule (natural-vent-sch) is set to allow the windows to be opened anytime during the day or season. The ventilation temperature schedule (vent-temp-sch) is set to a constant $68^{\circ} \mathrm{F}$, forcing the windows closed if the indoor temperature falls below this value. Given that there is a cooling load, the outdoor temperature is below the indoor temperature, and the window is not already open, the probability of the window being open is set at a constant $50 \%$. Any changes from these assumptions should be documented.

Another aspect of occupant-induced infiltration is doors opening for entry and windows opened for reasons not based on temperature considerations (i.e., for fresh air). Opening doors for entry typically leads to very small amounts of infiltration and is usually considered "lost in the noise" of the overall infiltration rate. As such, no explicit accounting is made of this. Also, no special considerations are given to unpredictable and atypical infiltration caused by occupant behavior.

Natural Infiltration. Natural infiltration is caused by air passages between the house and the outdoors, pressure differences caused by wind, and the temperature difference between the indoors and outdoors. 
Blower door measurements lead to estimates for the leakage area of the house and the natural infiltration rate. Whereas DOE-2 includes an infiltration model based on leakage area, it is only applicable to single-zone models. A simple ACH model is usually an acceptable alternative. The disadvantage of an $\mathrm{ACH}$ model is that it does not capture the increased infiltration during periods of very high and low outdoor temperatures, when the load due to the infiltration is also higher.

An example of the BDL code under the SPACE command used to specify natural infiltration:

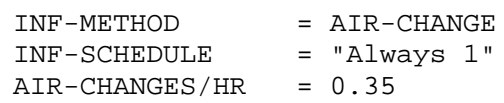

The schedule, which acts as a multiplier on the specified air-change per hour, is set to a constant value of 1.0 .

An alternative method that captures the variation in infiltration rate due to wind and temperature, but which requires considerable more effort to create, is an adjusted leakage area model. The concept is to use the Sherman-Grimsrud (S-G) leakage area method for all conditioned zones, but adjust the leakage area so the resulting annual average infiltration rate is the estimated natural infiltration rate. In this way, the S-G method will provide hourly variations in the infiltration rate while still relying on the natural infiltration calculations of the blower door test.

A similar approach could be taken using the infiltration method described for occupant behavior. In either case, it is important to review the profile of hourly infiltration rates calculated by the program using DOE-2's hourly reports before accepting the results.

Mechanical Ventilation of Bathrooms and Kitchens. If mechanical ventilation is specifically used to supply outside air to the house, either continuously or with a fixed schedule, the increased infiltration and electric usage of the fan must be accounted for. If, on the other hand, kitchen and bathroom exhaust fans are turned on by the occupants on an intermittent basis to control humidity or odors, the unpredictable increase in infiltration and electricity does not need to be included in the model.

Unfortunately, the residential system in DOE-2 does not include exhaust fans, and the associated increase in outdoor air must be accounted for in the overall house infiltration. The electric usage of the fan should not be included in the indoor loads, because nearly all of the heat generated by the fan is exhausted. Instead, outdoor electric loads can be added to the main electric meter command in DOE-2 or the electric usage can be added after the DOE-2 simulation.

Infiltration Based on Hourly Measurements. This method is potentially the most accurate way to characterize the hourly infiltration rate caused by natural infiltration and HVAC system operation. Its application is limited, however, because of the data needed to establish the proper inputs.

Hourly data are needed for actual infiltration rate, HVAC system run-time, local wind speed, average indoor temperature, and outdoor temperature. The time period for the hourly data must span a variety of wind speeds and outdoor temperatures in order to produce reliable regression coefficients. These data are typically collected under test conditions for a period ranging from several days to a couple weeks. 
If the proper data is available, simple linear regression can produce an equation that predicts the infiltration rate as a function of wind speed and the indoor-outdoor temperature difference:

$$
\text { Infiltration }=\mathrm{c} 0+\mathrm{c} 1 * \text { Wind Speed }+\mathrm{c} 2 *\left|\mathrm{~T}_{\mathrm{in}}-\mathrm{T}_{\text {out }}\right|
$$

Where: $\mathrm{c} 0, \mathrm{c} 1$, and $\mathrm{c} 2$ are regression coefficients, $\mathrm{T}_{\text {in }}$ is the indoor temperature, and $\mathrm{T}_{\text {out }}$ is the outdoor temperature.

If extrapolating the simulation model to a full year using standard weather files, it is important to adjust the average wind speed measured at the site to the average wind speed for the same period in the yearly weather data used for the annual simulation.

In this case, these inputs are used in the DOE-2 input file:

$$
\begin{array}{ll}
\text { INF-METHOD } & =\text { RESIDENTIAL } \\
\text { RES-INF-COEF } & =\text { (infconst [], infwind [], infdeltat []) } \\
& \$ \text { const, wind, deltaT coefficients }
\end{array}
$$

The three coefficients are input with macros set elsewhere in the BDL code, so that they can be easily changed based on the specific model being simulated.

\section{Building Operation}

Typically, varying levels of confidence are held in the many inputs required to properly model the house. The most variable component, by far, is the building operation. Building operation includes most of the occupant-controlled aspects of energy use, including thermostat set points, window management, hot-water usage, and natural ventilation. This document presents a set of standard schedules, set points, and variables associated with the building and equipment operation that should be used for the base cases and the prototype. Any deviations from these standards must be clearly pointed out in the modeling report and justification should be documented.

Internal gain schedules vary the amount of heat gain from appliances and lights throughout the day.

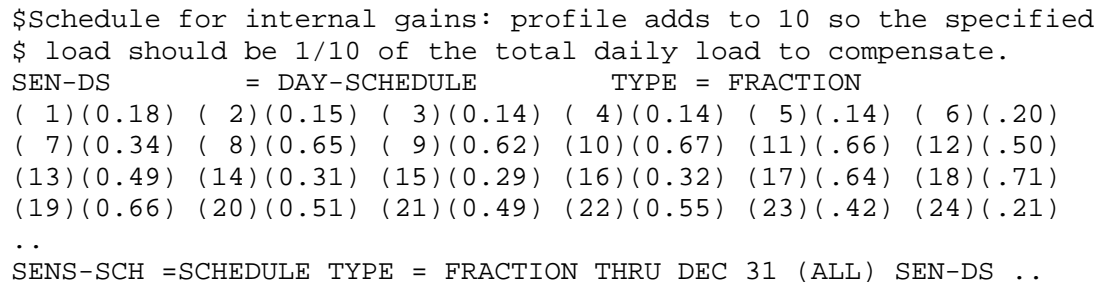

The actual internal gains are specified in the SPACE-CONDITIONS command, using the following BDL code:

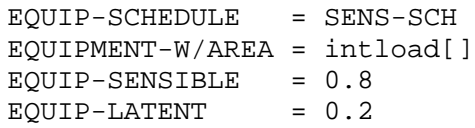


The equipment intensity is calculated based on the house size, using the following formula (presented in BDL macro language). Note that the load is divided by 10 to compensate for the schedule adding up to 10 instead of 1 .

\#\#set1 intload \#[\#[\#[\#[HoUSEarea[]*12.5]+15000]/3.413/10]/HOUSEarea [] ]

Note: If the analyst has information about how equipment heat gains vary by space (i.e., bedrooms and nonbedrooms), separate schedules could be created. However, the total daily heat gain due to this component should still equal the calculated "intload." The schedules or loads would, therefore, need to be weighted by the area of each space.

Occupancy schedules control when people are in various spaces. The following schedules define different occupancy patterns for bedrooms and nonbedroom areas and vary from weekday to weekend.

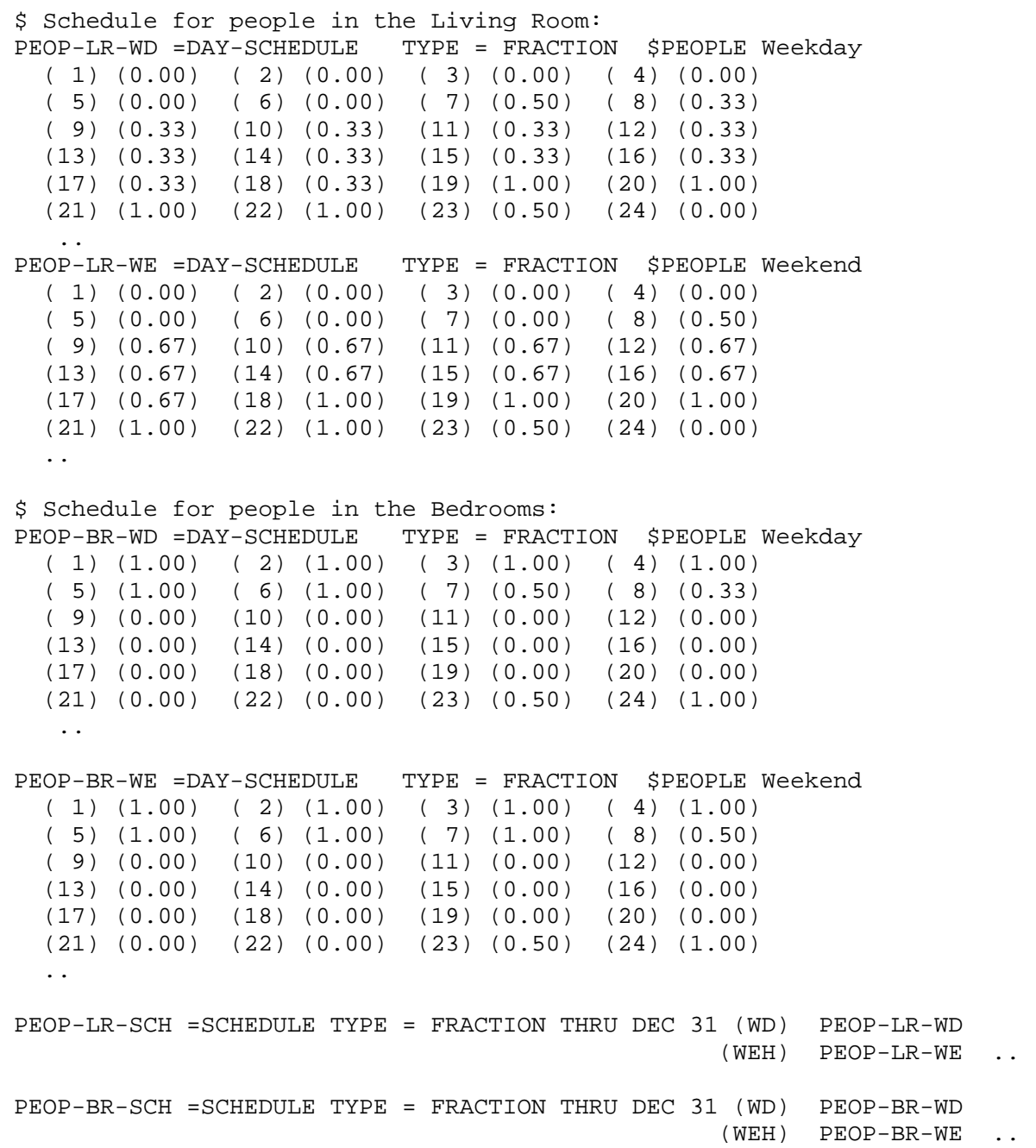

The actual number of people in each space is specified in the SPACE-CONDITIONS command. The standard number of people in the house is the number of bedrooms plus one. Because the schedules defined above do not overlap, the total number of people specified for all of the bedrooms should equal this number, and the total number of people in the other spaces should equal this number, as well. 
Thermostat schedules are defined for heating and cooling. The cooling schedule uses a set point of $78^{\circ} \mathrm{F}$, and the heating schedule uses a set point of $68^{\circ} \mathrm{F}$.

\section{Window Management}

Draperies are assumed to be drawn over half of the windows all of the time. An equivalent interpretation could be that all of the windows have their curtains drawn half of the time. In either case, each window has a shading multiplier and a conduction multiplier. The drawn curtains are assumed to decrease the solar gain by $40 \%$ and add approximately an R- 0.5 to the fenestration. Screens are assumed to be present on half of the windows as well, and the combined dirt and screen is assumed to decrease solar gains by $10 \%$.

\section{Systems}

The DOE-2 "RESYS2" system type will be used for most residential systems. A new residential system type is available in the latest versions of DOE-2. The RESVVT system delivers variable temperature and variable volumes of air to individually controlled zones. More on this system type can be found in the DOE-2.2 documentation.

The RESYS2 system type is capable of simulating split system and unitary cooling systems, as well as direct and indirect evaporative cooling. Heating can be supplied from a gas furnace, electric resistance, or air-source heat pump. More sophisticated systems configurations, with ground loop heat exchangers, combined hydronic water heating, and other features can be modeled using the circulation loop approach described in the DOE-2.2 HVAC documentation.

The sample system BDL code included as Appendix B of this report provides a comprehensive model for most system types encountered.

\section{Modeling an Unvented Attic}

An accurate model of the attic is essential to capture the difference between a vented and unvented attic. Figure 5 shows the basic components for the vented attic model.

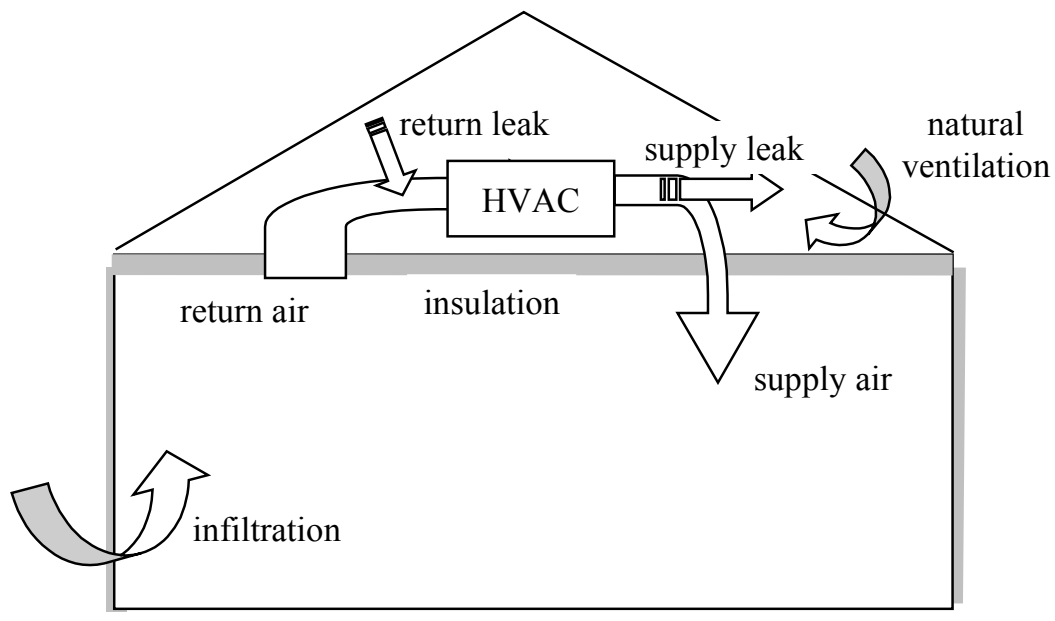

Figure 5. Vented attic scenario 
For the vented scenario, the attic is modeled as an unconditioned space, and all air loss to the attic is made up by outside air. The attic air-exchange rate is specified as $1.5 \mathrm{ACH}$ and the duct UA is calculated using R-5 duct insulation. Return leaks add air from the attic to the return air stream, which may be quite different from the outside air temperature. Currently, DOE-2 cannot directly model this effect. An equivalent heat transfer can be approximated using an air wall between the attic and the main house space in addition to the normal ceiling, with a total UA equivalent to the heat flow to the return air. In either case, the result is an additional load on the HVAC system equal to the amount of energy necessary to raise or lower the temperature of the return air leak from the attic temperature to that of the conditioned space. The area of the air wall would be:

$$
\text { Area }=1.08 \cdot \mathrm{CFM}_{\text {ret }} / \mathrm{U}_{\text {airwall, }}
$$

Where: $\mathrm{U}_{\text {airwall }}$ is an arbitrary thermal conductivity that results in a reasonable value for area.

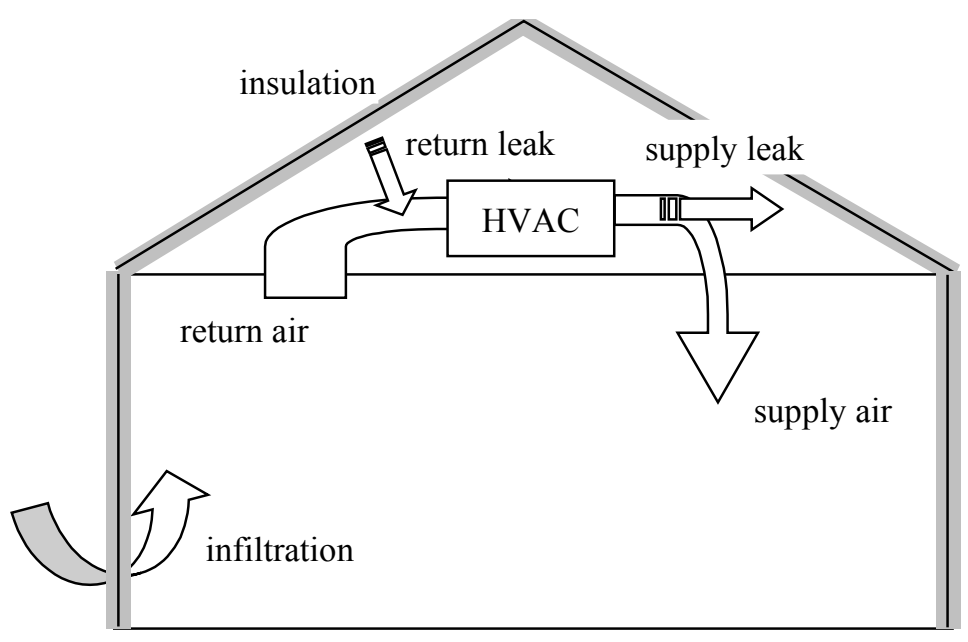

\section{Figure 6. Unvented attic scenario}

The unvented attic model, as depicted in Figure 6, has the insulation in the roof portion of the attic, creating a much tighter space and minimizing the natural ventilation in the attic. For the DOE-2 simulation, the attic is modeled as a conditioned space, with a supply CFM specified equivalent to the duct leakage. It is assumed that the negative pressure in the house and positive pressure in the attic caused by the duct leakage are balanced by exchange between the attic and house, rather than by inducing increased outdoor airflow to the house. By modeling the space as conditioned and assigning a supply airflow rate, additional outside air will not be modeled.

The case of the unvented roof compared with a traditional vented roof is an example of rather complicated thermodynamics that cannot be entirely modeled using the standard options of DOE-2. It is important to test the sensitivity of each assumption and identify a range of possible results or areas where further research would be helpful. 


\section{Support Programs}

\section{PowerDOE and eQUEST}

PowerDOE and eQUEST are Microsoft Windows ${ }^{\mathrm{TM}}$-based programs that provide a graphical interface to the DOE-2.2 program. Both programs provide on-line help and a three-dimensional view of the modeled building. These programs can be used to create and simulate the residential models for Building America, because they provide complete access to all of the DOE-2.2 features. Because the Building America residential models are all fairly similar in scope and relatively simple; however, using these programs will not necessarily make the process any easier or faster.

eQUEST is a freeware program and features a "building creation wizard" that helps the user create a complex commercial building with relatively few inputs. However, this approach is not geared toward residential buildings. eQUEST can read DOE-2.2 input files and is a very handy tool for checking the geometry of walls, windows, and floor plans of existing simulation models. Most of the graphics included in this report were generated by eQUEST.

eQUEST can be downloaded, at no cost, from http://www.doe2.com. After installing the program, it is quite easy to import DOE-2.2 input files:

1. From the Top Menu, choose File - New - Blank Slate

2. From the Top Menu, choose Import

3. Choose Import File type of *.INP

4. Browse to your DOE-2.2 input file

eQUEST will compile your input file and report any errors it finds. Press the Building Geometry button to view your building in two or three dimensions. In the three-dimensional view, you can zoom in and out by holding down the Control key and right mouse button while moving the mouse forward and backward. You can rotate the building by holding down the Control key and left mouse button while moving the mouse.

The help files included with both of these programs contain detailed command and key-word explanations as well as topic discussions. These help files can be used independently or from within the program.

\section{PRC-Tools}

The Partnership for Resource Conservation (PRC) has created some useful tools that are available to Building America contractors, and run DOE-2.2 and extract results from the program.

PRC-Run22 allows the user to define all of the runs for a Building America analysis by entering the macros and parameters that define each run into a spreadsheet-like interface. All required simulations for the analysis can then run with the push of a single button. The program will also grab specified results from each output file and copy them to a common output file, formatted for easy import into a spreadsheet program. This process allows for consistent reporting and facilitates updating existing projects. 
Run Spectications |DOE2 options |

developed by

The Partnership for Resource Conserration

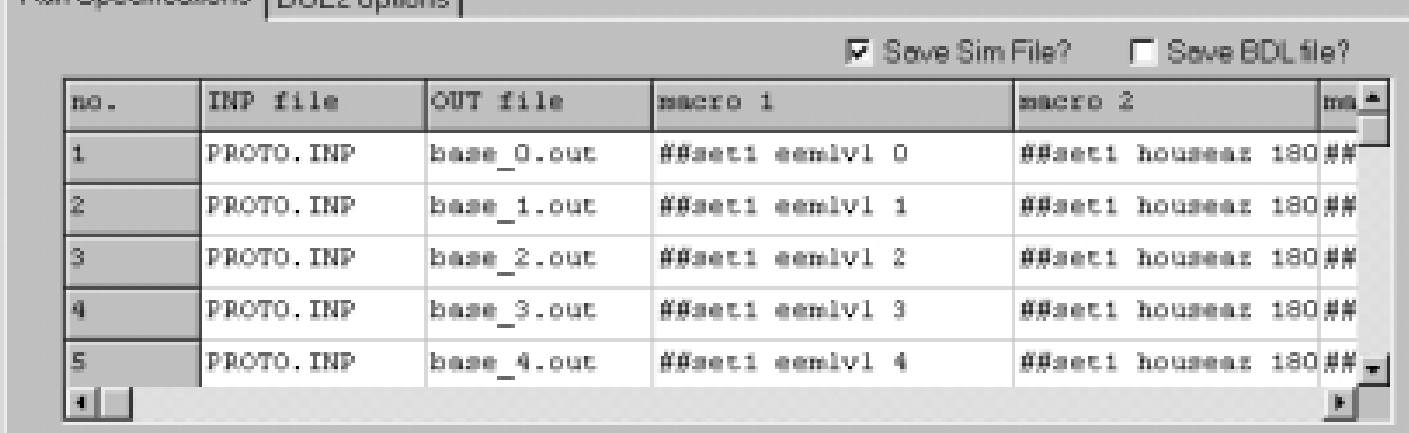

DA-Punz2 ... a batch processor for Duilding lmerica knalgsis

Developed under contract to NREL,

Funded by ebe Department of Energy's Building borica Program

Progras written by Paul Reeves The Partnersbip for Resource Conservation

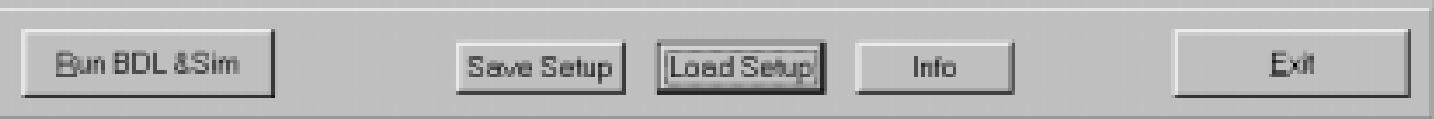

Figure 7. PRC's BA-Run22 main input screen

All of the program specifications can be saved to, and loaded from, a text file. This allows the user to save the specifications for an analysis and use them to reproduce or modify the entire analysis at a later date. The program remembers the last executed analysis and loads that information at start-up.

The BA-Run22 program must reside in the same directory as the WinDOE-2 program supplied with the latest DOE-2.2 installation, typically the "DOE2DLL" subdirectory underneath the main DOE-2 directory. 


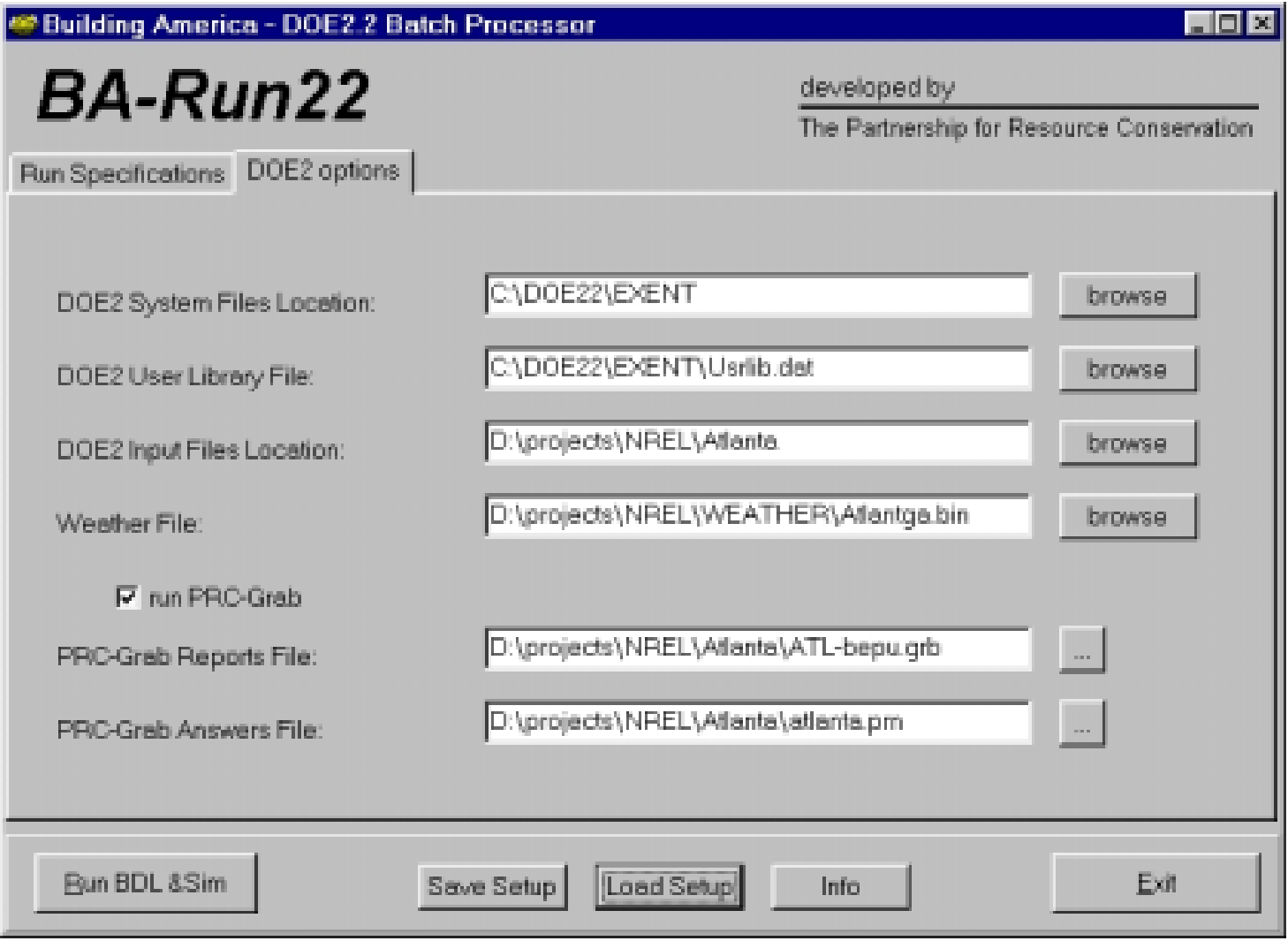

Figure 8. PRC's BA-Run22 options screen

The second tab of the main screen configures the program for the local machine's DOE-2 program, as well as the current project. The "DOE2 System Files Location" should point to the EXENT subdirectory created when DOE-2.2 was installed. The User Library File can specify a custom library file or the standard "usrlib.dat" file supplied with the DOE-2 program. The "Input Files Location" is the subdirectory of the current project; the input file of interest must reside in this directory. Finally, the weather file must be specified for the current analysis.

The full functionality of another tool, PRC-Grab, is integrated into BA-Run22. When the "run PRCGrab" checkbox is checked, the user can enter a "grab" file that specifies the results needed and a common file to write the results to. PRC-Grab will extract any number of results from the DOE-2 output and append it to a common file.

Grab File Description. The grab file contains information regarding which answers are to be extracted from the DOE-2 output. You must specify in which DOE-2 report the answers are located and then indicate which line of the report contains the answer. The line can be specified as either a certain number of lines from the top of the report or a line that contains a unique string of text. 
Here is an example grab file; you can use these lines as a starting point for your own grab file.

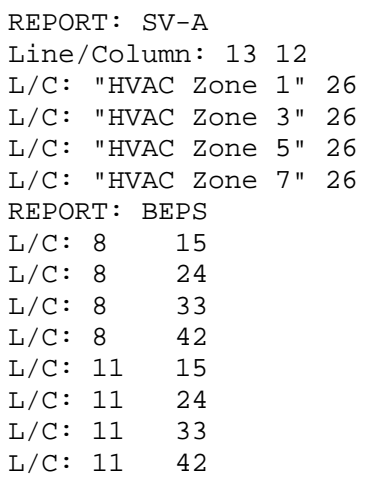

Note: If you want to skip to the third SV-A report, add a "3" after the SV-A report name (i.e., REPORT: SV-A 3).

If you want to add two values together before saving, add "PLUS" to the end of the first value's line. The following example will add the values found at columns 15, 24, and 33 in line 8 of the BEPS report before saving the value to the Answer file. "PLUS" can span across reports as well:

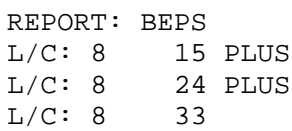

This next example adds values from three different SV-A reports. If you want to multiply a value by a constant before saving, add "TIMES" and a value after the specification:

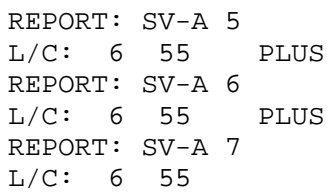

This example adds together the cooling capacities from nine zonal systems. Four of the systems have space multipliers of 3, therefore, they are multiplied before being added to the total.

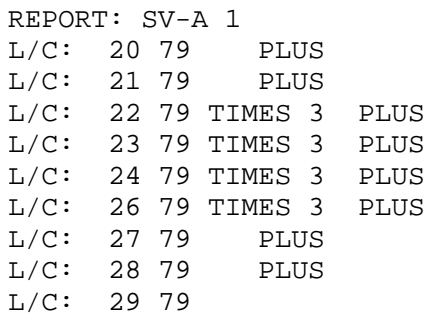


The following example shows a grab file used for a typical Building America analysis.

\section{Sample Building America Analysis Grab File}

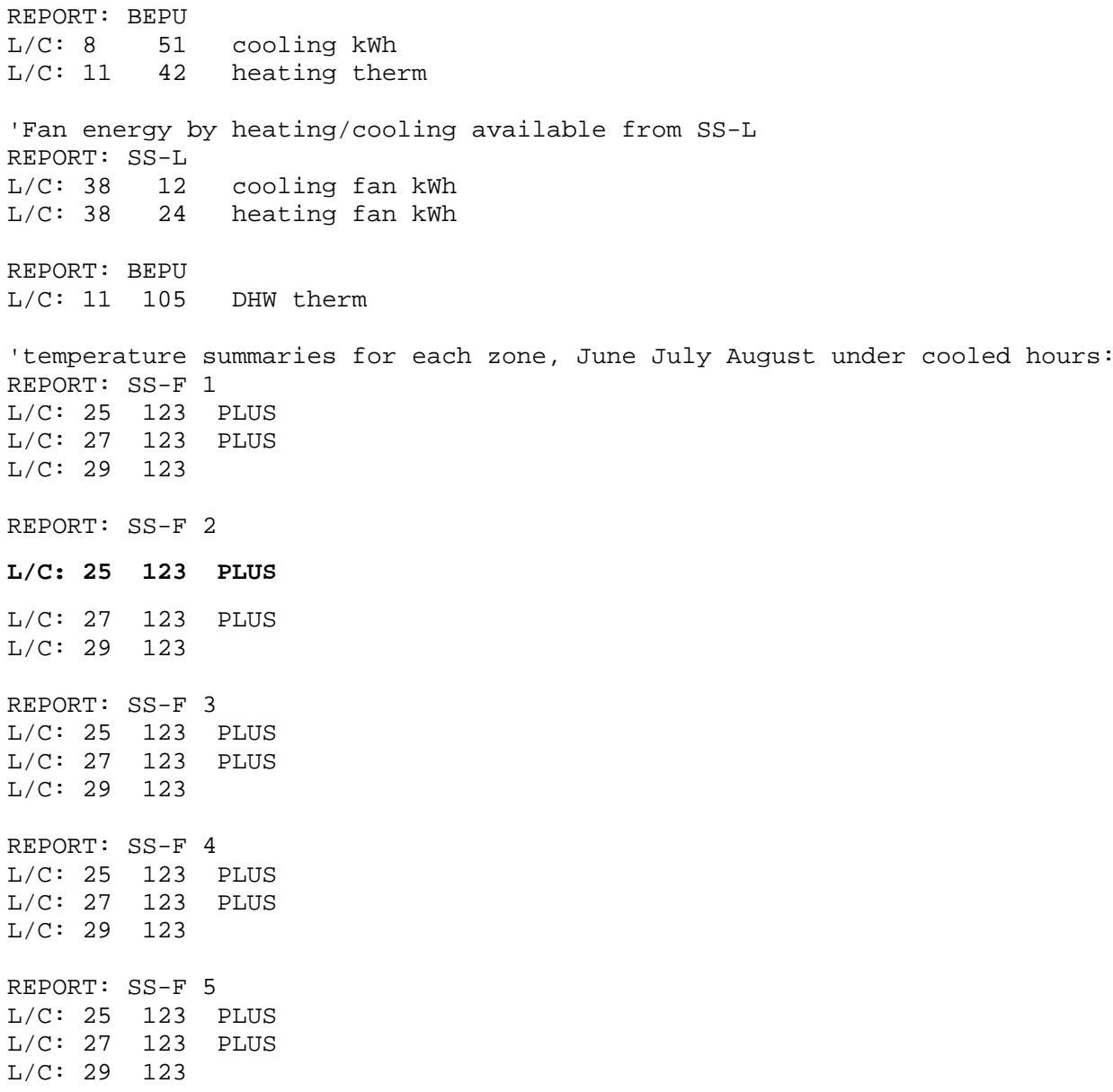


Appendix A.

Energy Star Rating Guidelines Using NASEO RESNET Methodology for the Home Energy Rating System (HERS) 
National Association of State Energy Officials (NASEO)

\section{NATIONAL HOME ENERGY RATING TECHNICAL GUIDELINES}

September 19, 1999

(As published June 9, 2000)

\section{A. GENERAL PROVISIONS}

1. Purpose. The provisions of this document are intended to establish national residential energy efficiency rating Guidelines, consistent with the provisions of the Energy Policy Act of 1992, which any provider of home energy ratings may follow to produce uniform energy efficiency ratings for residential buildings.

a. Relationship to other Guidelines. These Guidelines are a companion document to the "National Accreditation Procedures for Home Energy Rating Systems" as promulgated and maintained by the National Association of State Energy Officers (NASEO) and the Residential Energy Services Network (RESNET), and recognized by the mortgage industry.

b. Relationship to State Law. These Guidelines specifically recognize the authority of each state that has a state law or regulation which requires certification or licensing of home energy rating systems. To the extent that such state laws or regulations differ from these Guidelines, state law or regulation shall govern.

2. Scope. These Guidelines apply to existing or proposed, site-constructed or manufactured, one and two family residential buildings, or other residential buildings three stories or less in height excepting hotels and motels.

\section{Definitions and acronyms.}

Accreditation Procedures - The set of standards and procedures entitled "Mortgage Industry National Accreditation Procedures for Home Energy Rating Systems" as published and maintained by NASEO and RESNET.

Adiabatic - A condition wherein heat neither enters nor leaves a system.

Annual Fuel Utilization Efficiency or AFUE - The ratio of annual output energy to annual input energy that includes any non-heating season pilot input loss.

Climate zone - A geographical area defined as having similar long-term climate conditions.

$C O P$ - Coefficient of Performance, which is the ratio of the rate of heat delivered to the rate of energy input, in consistent units, for a complete heat pump system under designated operating conditions.

Conditioned space boundary - The continuous planes of the building envelope that comprise the primary thermal and air flow barrier between the directly or indirectly conditioned space and either the outdoors or an adjacent unconditioned space.

Confirmed Rating - An energy rating accomplished using data gathered from an on-site audit inspection and, if required, performance testing of the physical building and its installed systems and equipment.

Data analyst - A person trained to enter the information compiled by a data collector into the rating tool and to produce the energy efficiency rating of a home.

Data collector - A person trained to evaluate the minimum rated features of a home on site and collect all the information required to create a rating. 
Detached one- and two-family dwelling - A building with one or two independent dwelling units with an individual or central HVAC system.

Directly Conditioned space - An enclosed space having heating equipment with a capacity exceeding $10 \mathrm{BTU} / \mathrm{hr}^{-\mathrm{ft}^{2}}$, or cooling equipment with a capacity exceeding to 10 $\mathrm{BTU} / \mathrm{hr}-\mathrm{ft}^{2}$. An exception is if the heating and cooling equipment is designed and thermostatically controlled to maintain a process environment temperature less than $65^{\circ}$ Fahrenheit or greater than $85^{\circ}$ Fahrenheit for the whole space the equipment serves.

Distribution System Efficiency - A system efficiency factor, not included in manufacturer's performance ratings for heating and cooling equipment, that adjusts for the energy losses associated with the delivery of energy from the equipment to the source of the load, such energy losses associated with heat transfer across duct or piping walls and air leakage to or from forced air distribution systems.

Energy analysis tool - A calculation procedure for determining a home's energy efficiency rating and estimating annual purchased energy consumption and cost.

$E E R$ - Energy Efficiency Ratio, which is the ratio of net equipment cooling capacity in Btu/h to total rate of electric input in watts under designated operating conditions.

Energy efficiency rating or rating - An unbiased indication of a home's relative energy efficiency based on consistent inspection procedures, operating assumptions, climate data and calculation methods.

Energy factor - A measure of water heater energy efficiency as determined under Department of Energy Regulations, 10 CFR 430.23(e)(2)(ii).

Energy saving measure or feature - Any material, component, device, system, construction method, process or combination thereof that will result in a reduction of energy use.

EPAct - The U.S. Energy Policy Act of 1992.

Estimated annual energy cost savings - Positive dollar difference between estimated annual energy costs for a home with energy saving measures and estimated annual energy costs of the same home in its current condition.

Exposed wall - Walls subjected to heat loss or gain.

Fenestration - A glazed opening and its associated sash and framing that is installed into a building.

Guidelines (HERS Guidelines) - Minimum criteria that a HERS Provider must meet in order to receive accreditation.

$H E R S$ - Home energy rating system.

HERS-BESTEST - The Home Energy Ratings System Building Energy Simulation Test published in NREL Report No. NREL/TP-472-7332.

HERS provider - A person or organization that develops, manages, and operates a home energy rating system.

Home - A one or two family dwelling or multi-family dwelling of three stories or less.

Home energy rater or rater - The person trained to perform the functions of both a data collector and a data analyst, and to inspect a home to evaluate the minimum rated features and prepare an energy efficiency rating (see also Data collector and Data analyst).

Home Energy Rating System or HERS - The materials and procedures needed to operate a home energy rating program including but not limited to: marketing materials, training materials, publications, rating tool, quality control, data bases collection and maintenance, agreements, data collection sheets, home owner reports, and other related materials and services.

$H S P F$ - Heating Seasonal Performance Factor which is the total heating output of a heat pump during its normal annual usage period for heating, in Btu, divided by the total electric energy input during the same period, in watt-hours. 
HVAC - Heating, Ventilating and Air Conditioning.

Indirectly Conditioned space - Enclosed space that is not directly conditioned:

(1) With area weighted heat transfer coefficient (U-value) to directly conditioned space exceeding that to the outdoors or to unconditioned spaces; or

(2) through which air to or from directly conditioned spaces is transferred at a rate exceeding three air changes per hour.

Internal gains - The heat gains within a home attributable to lights, people, and miscellaneous equipment including domestic hot water equipment losses.

MEC ' 93 - the Model Energy Code as promulgated by the Council of American Building Officials (CABO) in 1993 as amended in 1994.

NASEO - National Association of State Energy Officers.

NREL - National Renewable Energy Laboratory.

Projected Rating - A rating performed prior to the construction of a new building or prior to implementation of energy-efficiency improvements to an existing building.

Purchased energy - The portion of the total energy requirement of a home purchased from a utility or other energy supplier.

Rated Home - The specific home being evaluated using the rating procedures and Guidelines contained in this document.

Rating tool - A procedure for calculating a home's energy efficiency rating, annual energy consumption, and annual energy costs.

Reference Home - A hypothetical home configured in accordance with the specifications set forth in Section B.4 of these Guidelines.

RESNET - Residential Energy Services Network.

$R$-value - thermal resistance value measured in $\mathrm{h}-\mathrm{ft}^{2}-\mathrm{F} / \mathrm{Btu}$.

SEER - Seasonal Energy Efficiency Ratio, which is the total cooling output of an air conditioner during its normal annual usage period for cooling, in Btu/h, divided by the total electric energy input during the same period, in watt-hours.

Thermal boundary wall - Any wall that separates directly or indirectly conditioned space from unconditioned space or ambient conditions.

Above grade thermal boundary wall is any thermal boundary wall not in contact with soil.

Thermal storage mass - Materials or equipment incorporated into a home that will store heat, produced by renewable or non renewable energy, for release at a later time.

Typical Meteorological Year or TMY Data - Hourly climate data published by the National Climatic Center, Asheville, NC, based on historical climate data in 216 locations.

$U$-value - Thermal transmittance value measured in $\mathrm{Btu} / \mathrm{h}-\mathrm{ft}^{2}-\mathrm{F}$.

\section{B. TECHNICAL REQUIREMENTS FOR CONDUCTING RATINGS}

\section{Rating procedure}

a. To determine the energy efficiency rating of a home, all HERS provider shall-

(1) If rating an existing home, visit the home to collect the data needed to calculate the rating;

(2) If rating a new, to-be-built home, follow the procedures set forth in Section B.8 of these Guidelines to collect the data needed to calculate the rating;

(3) Use the collected data to estimate the annual purchased energy consumption for heating, cooling and water heating for both the Rated Home and the Reference Home as defined in Section B.4 of these Guidelines. 
(4) If the energy efficiency rating is conducted to evaluate proposed energy conserving improvements to the home, calculate additional estimates of annual purchased energy consumption with the home reconfigured to include those improvements sufficient to consider interactions among improvement options.

b. Estimates completed by all HERS providers under paragraphs a.(3) and a.(4) of this section must be-

(1) Based on the minimum rated features set forth in Section B.5 of these Guidelines.

(2) Conducted using the standard operating assumptions established in Section B.6 of these Guidelines.

(3) Conducted using an energy analysis (rating) tool that has been certified for accuracy under Section C.1 of these Guidelines.

c. All HERS providers shall compare the estimates provided under paragraph B.1.a. of this section to determine the energy efficiency rating of the home and, if applicable, the energy efficiency rating of the home with proposed conservation measures installed.

d. To encourage the use of energy efficient lights and appliances, HERS providers may provide additional information on estimated lights and appliance energy consumption in the Rated Home. This information shall not change the rating score set forth in Section B.2.a. of these Guidelines.

\section{Rating point score and star rating.}

a. Point score. The Reference Home shall have a point score of 80 points on a 0 to 100 point scale. Each 5\% increase or decrease in the relative energy efficiency potential of the Rated Home with respect to the Reference Home shall constitute a 1-point increase or decrease, respectively (from 80), in the Rated Home's score. The method used to calculate the score shall be approved by the accrediting body and be consistent for each HERS provider operating within a state. Except in states or territories whose laws or regulations require a specific alternative method, which shall control, equations 1 and 2 shall be used in a 2-step process to calculate the point score for the Rated Home, as follows:

Step (1) Calculate the individual normalized Modified End Use Loads (nMEUL) for heating, cooling, and hot water using equation 1 :

nMEUL $=$ REUL * $\left(\mathbf{n E C} \_\mathbf{x} /\right.$ EC_r $)$

where:

nMEUL = normalized Modified End Use Loads (for heating, cooling or hot water).

REUL $=$ Reference Home End Use Loads (for heating, cooling or hot water) as computed using accredited simulation tools.

nEC_x $=$ normalized Energy Consumption for Rated Home's end uses (for heating, cooling or hot water).

EC_r = estimated Energy Consumption for Reference Home's end uses (for heating, cooling or hot water) as computed using accredited simulation tools. 
and where:

$n E C \_x=\left(a * E_{-} C_{-} x-b\right) *\left(E C \_x * E_{-} C_{-} r * D_{S E} r\right) /($ EEC_x $*$ REUL $)$

where:

EC_x = estimated Energy Consumption for the Rated Home's end uses (for heating, cooling or hot water) as computed using accredited simulation tools.

EEC_x $=$ Equipment Efficiency Coefficient for the Rated Home's equipment, such that EEC_x equals the energy consumption per unit load in like units as the load, and as derived from the Manufacturer's Equipment Performance Rating (MEPR) such that EEC_x equals 1.0 / MEPR for AFUE, COP or EF ratings, or such that EEC_X equals 3.413 / MEPR for HSPF, EER or SEER ratings.

$D S E \_r=R E U L / E C \_r * E E C \_r$

For simplified system performance methods, DSE_r equals 0.80 for heating and cooling systems and 1.00 for hot water systems. [see Section B.4.a.(17)]. However, for detailed modeling of heating and cooling systems, DSE_r may be less than 0.80 as a result of part load performance degradation, coil air flow degradation, improper system charge and auxiliary resistance heating for heat pumps. Except as otherwise provided by these Guidelines, where detailed systems modeling is employed, it must be applied equally to both the Reference and the Rated Homes.

EEC_r $=$ Equipment Efficiency Coefficient for the Reference Home's equipment, such that EEC_r equals the energy consumption per unit load in like units as the load, and as derived from the Manufacturer's Equipment Performance Rating (MEPR) such that EEC $\mathrm{x}$ equals 1.0 / MEPR for AFUE, COP or EF ratings, or such that EEC_x equals 3.413 / MEPR for HSPF, EER or SEER ratings.

and where the coefficients ' $a$ ' and ' $b$ ' are as defined by Table 1 below:

Table 1. Coefficients ' $a$ ' and ' $b$ '

\begin{tabular}{||l|c|c||}
\hline \hline Fuel type and End Use & $\mathrm{a}$ & $\mathrm{b}$ \\
\hline Electric space heating & 1.9924 & 0 \\
\hline Natural gas space heating & 1.2544 & 0.6082 \\
\hline Fuel oil space heating & 2.4321 & 2.1180 \\
\hline Electric air conditioning & 2.9301 & 0 \\
\hline Electric water heating & 0.8800 & 0 \\
\hline Natural gas water heating & 0.9404 & 0.7415 \\
\hline Fuel Oil water heating & 1.5569 & 1.9376 \\
\hline
\end{tabular}


Step (2) Determine the point score using equation 2:

Point score $=100-(($ TnML / TRL $) * 20)$

(Eq. 2)

where:

$$
\begin{aligned}
\mathrm{TnML}= & \mathrm{nMEUL}_{\mathrm{HEAT}}+\mathrm{nMEUL}_{\mathrm{COOL}}+\mathrm{nMEUL}_{\mathrm{HW}}(\text { Total of all } \\
& \text { normalized Modified End Use Loads as calculated using } \\
& \text { equation } 1) . \\
\mathrm{TRL}= & \text { REUL }_{\mathrm{HEAT}}+\mathrm{REUL}_{\mathrm{COOL}}+\mathrm{REUL}_{\mathrm{H} \mathrm{w}} \text { (Total of all } \\
& \text { Reference Home End Use Loads). }
\end{aligned}
$$

b. Star rating. The Rated Home will be given a star rating between one and five-plus stars, determined by the numerical score and the corresponding number of stars depicted in Table 2:

TABLE 2. Score, Star and Efficiency Scales for Rated Homes

\begin{tabular}{|c|c|c|}
\hline Score Range & Stars & $\begin{array}{c}\text { Relative Efficiency Change } \\
\text { (with respect to Reference Home) }\end{array}$ \\
\hline$=>0$ and $<20$ & $\star$ & $=>-400 \%$ and $<-300 \%$ \\
$=>20$ and $<40$ & $\star+$ & $=>-300 \%$ and $<-200 \%$ \\
$=>40$ and $<50$ & $\star \star$ & $=>-200 \%$ and $<-150 \%$ \\
$=>50$ and $<60$ & $\star \star+$ & $=>-150 \%$ and $<-100 \%$ \\
$=>60$ and $<70$ & $\star \star \star$ & $=>-100 \%$ and $<-50 \%$ \\
$=>70$ and $<80$ & $\star \star \star+$ & $=>-50 \%$ and $<0 \%$ \\
$=>80$ and $<83$ & $\star \star \star \star$ & $=>0 \%$ and $<15 \%$ \\
$=>83$ and $<86$ & $\star \star \star \star+$ & $=>15 \%$ and $<30 \%$ \\
$=>86$ and $<90$ & $\star \star \star \star \star$ & $=>30 \%$ and $<=50 \%$ \\
$=>90$ and $<=100$ & $\star \star \star \star \star+$ & $=>50 \%$ \\
\hline
\end{tabular}

\section{Rating report.}

a. For each rating conducted under this part, a report shall be prepared containing, at a minimum, the following information:

(1) The numerical rating score determined in Section B.2.a of these Guidelines;

(2) The star rating determined in Section B.2.b of these Guidelines, except that all plus $(+)$ ratings other than $5+$ are optional;

(3) The estimated annual purchased energy consumption for space heating, space cooling, domestic hot water, and all other energy use, and the total of these four estimates;

(4) The estimated annual energy cost for space heating, space cooling, domestic hot water, and all other energy use, and the total of these four estimates;

(5) The unique physical location (full street address or recorded real property identifier) of the Rated home;

(6) The name of the individual accomplishing the rating;

(7) The date the rating was accomplished; and

(8) The rating tool (including version number) used to calculate the rating; 
b. If ratings are conducted to evaluate energy saving improvements to the home, in addition to the information set forth under paragraph B.3.a of this section, each rating report must include-

(1) The estimated annual energy cost savings for the home reconfigured to include those improvements;

(2) The discount rate applied to, and present worth value of the energy cost savings; and

(3) The financing interest rate and the life of the measures used by the HERS provider to determine the present worth value.

c. The rating report must also provide either:

(1) The estimated lights and appliance energy consumption of the Rated Home: or

(2) Information that additional energy savings related to lights and appliance use may be attainable and that the information available on Energy Guide labels and from other recognized sources may be used to consider the energy efficiency of appliances.

d. If a Projected Rating conducted under Section B.8.a of these Guidelines, the Rating shall be identified as a Projected Rating.

e. For each rating conducted under these Guidelines, the following items are to be prominently displayed on all reports and labels:

(1) Date of the rating;

(2) Annual estimated energy costs for heating, cooling, water heating and all other use;

(3) Rating point score; and

(4) Star rating;

(5) As an alternative to reporting the rating point score and star rating, any home achieving a rating score of 86 or greater may, at the request of the person for whom the rating is being conducted, be labeled an ENERGY STAR $^{\circledR}$ Home.

\section{Reference Home configuration.}

a. All HERS providers shall establish a Reference Home used in an annual purchased energy consumption comparison with the Rated Home. The Reference Home is a hypothetical home having the following characteristics -

(1) The same shape and size as the Rated Home;

(2) The same area of surfaces bounding Conditioned Space as the Rated Home,

(3) All enclosure elements that meet, but not exceed, the requirements, expressed as $U$ and $U_{o}$ values, of Paragraph 502.2 of MEC ' 93 with the components that meet the $\mathrm{U}_{\mathrm{O}}$ requirement for walls determined by:

(a) For detached one and two family homes, the U-values for wall assemblies from Table $3 \mathrm{a}$; or

(b) For attached homes, the U-values for wall assemblies from Table $3 \mathrm{~b}$; and for all homes- 
Table 3a. Opaque wall $U$-values $\left(\mathrm{U}_{\mathrm{W}}\right)$ for detached homes

\begin{tabular}{|c|c||}
\hline $\begin{array}{c}\text { Heating degree days base 65 (HDD65) From } \\
\text { nearest location listed in Chapter 9 of } \\
\text { ASHRAE Standard 90.2 }\end{array}$ & $\begin{array}{c}\mathrm{U}_{\mathrm{w}} \text { air to air } \\
\text { Includes } \\
\text { framing }\end{array}$ \\
\hline$>13000$ & 0.038 \\
\hline $9000-12999$ & 0.046 \\
\hline $6500-8999$ & 0.052 \\
\hline $4500-6499$ & 0.058 \\
\hline $3500-4499$ & 0.064 \\
\hline $2600-3499$ & 0.076 \\
\hline$<2600$ & 0.085 \\
\hline
\end{tabular}

Table 3b. Opaque wall $U$-values $\left(\mathrm{U}_{\mathrm{W}}\right)$ for attached homes

\begin{tabular}{|c|c||}
\hline $\begin{array}{c}\text { Heating degree days base 65 (HDD65) From } \\
\text { nearest location listed in Chapter 9 of } \\
\text { ASHRAE Standard 90.2 }\end{array}$ & $\begin{array}{c}\mathrm{U}_{\mathrm{w}} \text { air to air } \\
\text { Includes } \\
\text { framing }\end{array}$ \\
\hline$>9000$ & 0.064 \\
\hline $7100-8999$ & 0.076 \\
\hline $3000-7099$ & 0.085 \\
\hline $2800-2999$ & 0.100 \\
\hline $2600-2799$ & 0.120 \\
\hline$<2600$ & 0.140 \\
\hline
\end{tabular}

(c) The U-values for fenestration calculated using Equation 3 or $\mathrm{U}=1.3$, whichever is less;

Equation 3: $\quad U_{F}=\left[\left(U_{O} \times A_{O}\right)-\left(U_{W} \times A_{W}\right)-8\right] / A_{F}$

Where:

$\mathrm{U}_{\mathrm{F}}=$ Required average U-value of the fenestration systems.

$\mathrm{U}_{\mathrm{O}}=$ Average $\mathrm{U}$-value requirement for walls from paragraph 502.2 of MEC '93.

$\mathrm{A}_{\mathrm{O}}=$ Gross exposed wall area, not including basement walls, of the Rated Home.

$\mathrm{U}_{\mathrm{w}}=$ Value from Table $2 \mathrm{a}$ or $2 \mathrm{~b}$ based on HDD65 criteria of Rated Home location.

$A_{W}=$ Net opaque wall area, calculated as: $A_{O}$ $\mathrm{A}_{\mathrm{F}}-40$.

$A_{F}=$ Area of fenestration calculated using the gross area calculated under Section B.4.a.7. of these Guidelines.

Note: For walls of attached homes, the U-value calculation in paragraph (3) above is completed using the fenestration area calculated as $A_{F}$ in Section B.4.a.7 of these Guidelines and the actual area of walls that experience heat loss or gain. Areas of common walls that separate homes are not included in $\mathbf{A}_{\mathbf{o}}$, Equation 3. 
(4) The same foundation type as the Rated Home, where:

(a) For Rated Homes on ventilated crawl spaces, assume for the Reference Home, insulation of the floor above the crawl space meeting the requirements of MEC ' 93 ;

(b) For Rated Homes on non-ventilated crawl spaces, assume for the Reference Home, insulation of the crawl space walls meeting the requirements of MEC '93;

(c) For Rated Homes on basements that are directly or indirectly conditioned spaces, assume for the Reference Home, insulation of the basement walls meeting the requirements of MEC ' 93 ; For Rated Homes with slab on grade construction, assume insulation of the slab edge meeting the requirements of MEC ' 93 ;

Solar absorptivity of opaque areas of exterior walls of 0.50 and of opaque areas of roofs of 0.75 ;

An area of exterior doors of 40 square feet, facing north, and with the door U-value at 0.20 .

Vertical fenestration area $\left(\mathrm{A}_{\mathrm{F}}\right)$ is determined-

(a) for one and two family detached homes, by equation 4;

(b) for attached homes, by equation 5 .

\section{Equation 4: $\quad A_{F}=0.18 \times A_{F L} \times F_{A}$}

\section{Equation 5: $\quad A_{F}=0.18 \times A_{F L} \times F_{A} \times F$}

Where:

$\mathrm{A}_{\mathrm{F}}=$ Total fenestration area.

$\mathrm{A}_{\mathrm{FL}}=$ Total floor area of directly conditioned space.

$\mathrm{F}_{\mathrm{A}}=$ (Above grade thermal boundary wall area) $/$ (total thermal boundary wall area).

$\mathrm{F}=($ Above grade thermal boundary wall area $) /($ above grade thermal boundary wall area + common wall area) $>=.56$

And where:

Thermal boundary wall is any wall that separates directly or indirectly conditioned space from unconditioned space or ambient conditions.

Above grade thermal boundary wall is any thermal boundary wall not in contact with soil.

(8) Vertical fenestration distributed-

(a) For detached homes, equally in each of the four cardinal directions, north, south, east and west; and

(b) For attached homes, equally in each of the four cardinal directions, north, south, east and west, which if necessary may require fenestration facing the same direction as common walls;

(9) A frame factor equal to $27 \%$ of the gross fenestration area calculated under Section B.4.a.7. of these Guidelines;

(10) The glazed area of the fenestration with a shading coefficient (SC) of 0.70 assumed during the cooling season, which represents the combined SC of the glazing and the use of nonwhite draperies; and with a SC of 0.88 , representing the $\mathrm{SC}$ of the glazing only, assumed at all other times; No external shading assumed at any time; 
Note: For the calculation of solar gains from all fenestration areas determined under Section B.4.a.7. of these Guidelines, the values in Table 4 are used to represent the combined effect of the framing factor in Section B.4.a.9. of these Guidelines and the glazed area shading coefficients in Section B.4.a.10. of these Guidelines.

Table 4. Shading and Solar Heat Gain Coefficients

\begin{tabular}{||l|l|l||}
\hline \hline Season & $\mathrm{SC}^{1}$ & SHGC $^{2}$ \\
\hline \hline Heating & 0.675 & 0.581 \\
\hline Cooling & 0.541 & 0.466 \\
\hline 1 & \multicolumn{2}{|c|}{ For calculation tools using shading coefficients } \\
2 & $\begin{array}{l}\text { For calculation tools using solar heat gain } \\
\text { coefficients as defined by NFRC 200. }\end{array}$
\end{tabular}

(12) The same fuel type for heating, cooling and water heating as used in the Rated Home.

(13) One each heating, cooling and hot water system of the same type as in the Rated Home except as required by the exceptions in Section B.4.a.14. of these Guidelines;

(14) If the Rated home contains multiple heating, cooling or water heating systems using different fuel types, then the applicable Reference Home system capacities and fuel types shall be weighted in accordance with the loads distribution (as calculated by accepted engineering practice for that equipment and fuel type) of the subject multiple systems.

(15) The minimum NAECA efficiency in effect on January 1, 1992 for the same type of HVAC equipment found in the Rated Home except that the efficiencies given in Table 5 will be assumed when;

(a) A type of device not covered by NAECA is found in the Rated Home;

(b) The Rated Home is heated by electricity using a device other than an air source heat pump; or

(c) The Rated Home does not contain one or more of the required HVAC equipment systems.

Table 5. Reference Home Equipment Efficiencies

\begin{tabular}{||l|l|l||}
\hline \hline Rated Home Fuel & Function & Reference Home Device \\
\hline \hline Electric & Heating & $\begin{array}{l}6.8 \text { HSPF Air Source Heat } \\
\text { Pump }\end{array}$ \\
\hline $\begin{array}{l}\text { Non Electric Warm } \\
\text { Air Furnace }\end{array}$ & Heating & $78 \%$ AFUE Gas Furnace \\
\hline Non Electric Boiler & Heating & $80 \%$ AFUE Gas Boiler \\
\hline Any Type & Cooling & $\begin{array}{l}10 \text { SEER Electric Air } \\
\text { Conditioner }\end{array}$ \\
\hline
\end{tabular}

(16) The sizing of HVAC equipment determined in accordance with accepted engineering practice for that equipment and fuel type. 
A distribution system efficiency of 0.80 , which is to be multiplied by the equipment efficiencies determined under Section B.4.a.15. of these Guidelines.

(18) The efficiency of the water heater;

(a) For Rated Homes with a storage type water heater, the minimum NAECA Energy Factor in effect on January 1, 1992 for the fuel type and size found in the Rated Home;

(b) For Rated Homes with a non-storage type water heater, the minimum NAECA Energy Factor in effect on January 1, 1992 is used to provide domestic hot water in the Rated Home.

(c) For Rated Homes without water heaters, the minimum NAECA Energy Factor in effect on January 1, 1992 for a 40 gallon storage type water heater using the same fuel as the predominant heating fuel type in the Rated Home shall be used for the purpose of calculating the HERS Score. (Note: This energy use may be excluded from the purchased energy cost estimate for the Rated Home.)

(19) An annual average air change rate as determined from normalized building leakage (nL) using Equation 6.

\section{Equation 6: $\quad \operatorname{ach}=n L \times$ W}

where:

ach $=$ average annual air changes per hour $\mathrm{nL}$ (normalized leakage) $=0.57$ for the Reference Home. $\mathrm{W}=$ Weather factor from $\mathrm{W}$ Tables in ASHRAE

Standard 136 for the site most climatologically representative of the Rated Home's location.

(20) An internal mass for furniture and contents of 8 pounds per square foot of floor area;

(21) Only the structural mass and associated heat capacitance calculated as follows:

(a) For masonry floor slabs, as found in the Rated Home;

(b) For masonry basement walls, as found in the Rated Home, but with any basement wall insulation as required under paragraph (3) assumed to be located on the interior side of the basement walls;

(c) For walls other than basement walls, for ceilings, floors, and interior partition walls, using equivalent areas to the Rated Home assuming light frame construction.

\section{Minimum rated features.}

a. All HERS providers shall calculate the estimated annual purchased energy consumption for heating, cooling and water heating set forth in Section B.1 of these Guidelines using the energy loss and gain associated with the minimum rated features set forth in Table 7.

b. For existing homes, the envelope thermal characteristics of building elements 1 through 7 set forth in Table 7 are determined by site observation.

c. If data for the minimum rated features set forth in paragraph (b) of this Section can not be obtained by observation or without destructive disassembly of the home, all HERS providers shall use default values. The default values are determined from the following sources listed in the preferential order of use:

(1) for manufactured homes, available manufacturer's data:

(2) current and historical local building practices; or

(3) current and historical local building codes. 
d. Default values set forth in paragraph (c) of this section shall be established or approved by the accrediting body and be consistent for all HERS providers operating within a state.

e. For existing homes, the determination of air leakage and duct leakage values set forth as building elements 10 and 11 in Table 7 are determined by data collected on site using the following procedures listed in preferential order of use: current on-site diagnostic tests conduced in accordance with nationally accepted pressurization test standards; or observations of the condition of the building and duct system made by the HERS provider. Based on these observations values used will be;

(a) for envelope air leakage, a minimum normalized leakage rate of $\mathrm{nL}=0.67$, where $\mathrm{nL}$ may be converted to an air change rate using Equation 6 of Section B.4.a(19) to compute average annual air changes per hour(ach); and

(b) for distribution system efficiency, default values in accordance with Table 6, below.

(3) The energy efficiency of the mechanical equipment set forth as building elements 12 through 14 in Table 7 is determined by data collected on site using the following sources listed in preferential order of use:

(a) current on-site diagnostic test data as corrected using the following equation:

Eff,rated $=$ Eff,listed $*$ Es,measured $/$ Es, listed

where:

Eff,rated $=$ annual efficiency to use as input to the rating Eff,listed $=$ listed annual efficiency by manuf. or directory

Es,measured $=$ measured steady state efficiency of system Es,listed = manufacturer's listed steady state efficiency, under the same operating conditions found during measurement

(b) name plate data;

(c) manufacturer's data sheet; or

(d) equipment directories. 
Table 6. Default Values ${ }^{1}$ for Distribution System Efficiencies

\begin{tabular}{|l|c|c|c|c||}
\hline \multirow{2}{*}{$\begin{array}{l}\text { Distribution System } \\
\text { Configuration and } \\
\text { Condition: }\end{array}$} & \multicolumn{2}{|c|}{ Forced Air Systems } & \multicolumn{2}{c||}{ Hydronic Systems } \\
\cline { 2 - 5 } & Heating & Cooling & Heating & Cooling \\
\hline $\begin{array}{l}\text { Observable leakage } \\
\text { pathways }{ }^{3} \text { with distribution } \\
\text { system components located } \\
\text { in } \text { unconditioned space }\end{array}$ & 0.70 & 0.70 & & \\
\hline $\begin{array}{l}\text { Observable leakage } \\
\text { pathways with entire } \\
\text { distribution system located } \\
\text { in conditioned space }\end{array}$ & 0.75 & 0.75 & & \\
\hline $\begin{array}{l}\text { Distribution system } \\
\text { components located in } \\
\text { unconditioned space }\end{array}$ & 0.80 & 0.80 & 0.95 & 0.95 \\
\hline $\begin{array}{l}\text { Entire distribution system } \\
\text { located in conditioned } \\
\text { space }\end{array}$ & 0.85 & 0.85 & 1.00 & 1.00 \\
\hline $\begin{array}{l}\text { Proposed "leak free" with } \\
\text { entire air distribution } \\
\text { system located in the } \\
\text { conditioned space }\end{array}$ & 1.00 & 1.00 & & \\
\hline $\begin{array}{l}\text { Proposed "leak free"air } \\
\text { distribution system with } \\
\text { components located in the } \\
\text { unconditioned space }\end{array}$ & 0.95 & 0.95 & & \\
\hline \begin{tabular}{l} 
"Ductless" 6 systems \\
\hline
\end{tabular} & 1.00 & 1.00 & & \\
\hline
\end{tabular}

Table 6 Notes:

1. Default values given by this table are for distribution systems that have been visually inspected only, and which meet MEC ' 93 minimum requirements for duct system insulation. Visual inspection is not the recommended method of determining forced air distribution system leakage. The recommended and preferred method of determining forced air distribution system leakage is through pressurization testing accomplished in accordance with Section B.5.e.(1) of this Guideline.

2. Hydronic systems shall mean those systems that distribute heating and cooling energy directly to individual spaces using liquids pumped through closed loop piping and that do not depend on ducted, forced air flows to maintain space temperatures.

3. Observable leakage pathways shall mean that elements of the air distribution system (including joints, seams, connection flanges, collars, boots, panned ducts, construction cavities used as airflow pathways, and other like system components) can be visually determined to contain one or more flaws through which unconditioned air may be forced into or out of the designated air duct system. 
4. Entire system in conditioned space shall mean that no component of the distribution system, including the air handler unit, is located outside of the plane of the conditioned space boundary. Conditioned space shall mean any building space directly or indirectly heated or cooled in accordance with the definitions provided in section A.3. of this Guideline. Any other air distribution system condition results in system components located in unconditioned space.

5. Proposed "leak free" shall mean substantially leak free as defined by the 1998 IECC (International Energy Conservation Code) to be a leakage rate of not more than $5 \%$ of the rated fan flow rate at a pressure differential of 25 Pascal across the entire system, including the manufacturer's air handler enclosure. This proposed condition is reserved for Projected Ratings and must be specified as the required performance in the construction documents. This proposed condition requires confirmation through field testing of installed systems.

6. Ductless systems may have forced air flow across a coil but shall not have any ducted air flows external to the manufacturer's air handler enclosure.

f. If the Rated Home does not utilize at least one each heating, cooling and hot water system, the Reference Home equipment efficiencies as specified in section B.4.a.(15) shall be assumed for the relevant missing system(s) in the Rated Home for the purposes of calculating the rating.

g. If the Rated Home utilizes multiple heating, cooling or hot water systems, the operating conditions specified in Section B.6 of these Guidelines shall be used for each system and the relevant purchased energy consumption calculations shall be appropriately weighted by system capacity in accordance with the loads distribution as calculated by accepted engineering practice for that equipment and fuel type.

h. If information on the energy efficiency of mechanical equipment cannot be determined from the sources listed in paragraph (3) of this section, the values set forth in Tables 8 and 9 shall be used.

i. $\quad$ Any HERS provider may base annual purchased energy consumption estimates for the Rated Home on additional features if the HERS provider's energy analysis tool is capable of doing so. 
TABLE 7.-- Minimum Rated Features

\begin{tabular}{|c|c|}
\hline Building element & Minimum rated features \\
\hline 1. Floor/Foundation Assembly. & $\begin{array}{l}\text { Construction type (slab-on-grade, crawl space; basement), } \\
\text { insulation (edge, under slab, cavity, sheathing), vented or } \\
\text { unvented (crawl space), capacitance (if slab or basement } \\
\text { receives appreciable solar gain). }\end{array}$ \\
\hline 2. Walls & $\begin{array}{l}\text { Construction type, insulation value (cavity, sheathing); } \\
\text { capacitance, color (light, medium, or dark). }\end{array}$ \\
\hline 3. Roof/Ceiling Assembly ... & $\begin{array}{l}\text { Construction type, insulation value (cavity, sheathing), roof } \\
\text { color (light, medium, or dark). }\end{array}$ \\
\hline 4. Rim Joist . . . . . . . . & Insulation value (cavity, sheathing). \\
\hline 5. Doors $\ldots \ldots \ldots \ldots \ldots \ldots$ & Construction type, insulation value. \\
\hline 6. Windows & $\begin{array}{l}\text { Construction type, orientation, U-value (of complete assembly), } \\
\text { solar heat gain coefficient, shading. }\end{array}$ \\
\hline 7. Skylights $\ldots \ldots \ldots \ldots \ldots \ldots$ & $\begin{array}{l}\text { Construction type, orientation, tilt, U-value (of complete } \\
\text { assembly), heat gain coefficient, shading. }\end{array}$ \\
\hline $\begin{array}{l}\text { 8. Passive Solar System (Direct } \\
\text { Gain system) } \ldots \ldots \ldots \ldots \ldots \ldots\end{array}$ & $\begin{array}{l}\text { Solar type, collector type and area, orientation, tilt efficiency, } \\
\text { storage tank size, pipe insulation value. }\end{array}$ \\
\hline $\begin{array}{l}\text { 9. Solar Domestic Hot Water } \\
\text { Equipment } \ldots \ldots \ldots \ldots\end{array}$ & $\begin{array}{l}\text { System type, collector type and area, orientation, tilt, efficiency, } \\
\text { storage tank size, pipe insulation value. }\end{array}$ \\
\hline 10. Air Leakage $\ldots \ldots \ldots \ldots \ldots$ & $\begin{array}{l}\text { Air leakage measurement type (default estimate, blower door } \\
\text { test, tracer gas test), volume of conditioned space. }\end{array}$ \\
\hline 11. Distribution System . & $\begin{array}{l}\text { System type, location, insulation value (duct and pipe), air } \\
\text { leakage measurement type (default estimate, duct blaster, } \\
\text { pressure pan threshold, blower door subtraction). }\end{array}$ \\
\hline 12. Heating Equipment & Equipment type, location, efficiency (AFUE, HSPF). \\
\hline 13. Cooling Equipment & Equipment type, location, efficiency (SEER, COP). \\
\hline $\begin{array}{l}\text { 14. Domestic Hot Water } \\
\text { Equipment } \ldots \ldots \ldots \ldots \ldots\end{array}$ & $\begin{array}{l}\text { Equipment type, location, energy factor or seasonal efficiency, } \\
\text { extra tank insulation value, pipe insulation value. }\end{array}$ \\
\hline 15. Control Systems & Thermostat type. \\
\hline
\end{tabular}


TABLE 8.- Default Values for Mechanical System Efficiency (Age-based)

\begin{tabular}{|c|c|c|c|c|c|c|c|c|}
\hline $\begin{array}{l}\text { Mechanical } \\
\text { Systems }\end{array}$ & Units & $\begin{array}{l}\text { Pre- } \\
1960\end{array}$ & $\begin{array}{l}1960- \\
69\end{array}$ & $\begin{array}{l}1970- \\
74\end{array}$ & $1975-83$ & $1984-87$ & $1988-91$ & $\begin{array}{l}1992 \text { to } \\
\text { present }\end{array}$ \\
\hline $\begin{array}{l}\text { Heating: } \\
\text { Gas Furnace } \\
\text { Gas Boiler } \\
\text { Oil Furnace or } \\
\text { Boiler } \\
\text { Air-Source } \\
\text { Heat } \\
\text { Pump . . } \\
\text { Ground-Water } \\
\text { Geothermal } \\
\text { Heat Pump } \\
\text { Ground- } \\
\text { Coupled } \\
\text { Geothermal } \\
\text { Heat Pump }\end{array}$ & $\begin{array}{l}\text { AFU } \\
\text { E } \\
\text { AFU } \\
\text { E } \\
\text { AFU } \\
\text { E } \\
\text { HSP } \\
\text { F } \\
\text { COP } \\
\text { COP }\end{array}$ & $\begin{array}{l}4.50 \\
2.70\end{array}$ & $\begin{array}{l}0.60 \\
0.60 \\
0.65 \\
4.50 \\
2.70\end{array}$ & $\begin{array}{l}0.65 \\
0.65 \\
0.72 \\
4.70 \\
2.70\end{array}$ & $\begin{array}{l}0.68 \\
0.65 \\
0.75 \\
5.50 \\
3.00\end{array}$ & $\begin{array}{l}0.68 \\
0.70 \\
0.80 \\
6.30 \\
3.10\end{array}$ & $\begin{array}{l}0.76 \\
0.77 \\
0.80 \\
6.80 \\
3.20\end{array}$ & $\begin{array}{l}0.78 \\
0.80 \\
0.80 \\
6.80 \\
3.50\end{array}$ \\
\hline $\begin{array}{l}\text { Cooling: } \\
\text { Air-Source } \\
\text { Heat } \\
\text { Pump .... } \\
\text { Ground-Water } \\
\text { Geothermal } \\
\text { Heat Pump } \\
\text { Ground- } \\
\text { Coupled } \\
\text { Geothermal } \\
\text { Heat Pump } \\
\text { Central Air } \\
\text { Conditioner } \\
\text { Room Air } \\
\text { Conditioner }\end{array}$ & $\begin{array}{l}\text { SEE } \\
\text { R } \\
\text { EER } \\
\text { EER }\end{array}$ & $\begin{array}{l}5.00 \\
10.00 \\
8.00 \\
5.00 \\
5.00\end{array}$ & $\begin{array}{l}6.10 \\
10.00 \\
8.00 \\
6.10 \\
6.10\end{array}$ & $\begin{array}{l}8.00 \\
6.50 \\
6.10\end{array}$ & $\begin{array}{l}7.40 \\
13.00 \\
11.00 \\
7.40 \\
6.70\end{array}$ & $\begin{array}{l}8.70 \\
13.00 \\
11.00 \\
8.70 \\
7.70\end{array}$ & $\begin{array}{l}9.40 \\
14.00 \\
12.00 \\
9.40 \\
8.10\end{array}$ & $\begin{array}{l}10.00 \\
16.00 \\
14.00\end{array}$ \\
\hline $\begin{array}{l}\text { Water Heating: } \\
\text { Storage Gas } \\
\text { Storage Oil } \\
\text { Storage } \\
\text { Electric }\end{array}$ & $\begin{array}{l}\text { EF } \\
\text { EF } \\
\text { EF }\end{array}$ & $\begin{array}{l}0.47 \\
0.47 \\
0.79\end{array}$ & $\begin{array}{l}0.47 \\
0.47 \\
0.80\end{array}$ & $\begin{array}{l}0.47 \\
0.47 \\
0.80\end{array}$ & $\begin{array}{l}0.49 \\
0.48 \\
0.81\end{array}$ & $\begin{array}{l}0.55 \\
0.49 \\
0.83\end{array}$ & $\begin{array}{l}0.56 \\
0.54 \\
0.87\end{array}$ & $\begin{array}{l}0.56 \\
0.56 \\
0.88\end{array}$ \\
\hline
\end{tabular}


TABLE 9.- Default Values for Mechanical System Efficiency (not Age-based)

\begin{tabular}{|c|c|c|}
\hline & Units & Rating \\
\hline \multicolumn{3}{|l|}{ Heating: } \\
\hline Gas Wall Heater (Gravity) & SE & 0.65 \\
\hline Gas Floor Furnace $\ldots \ldots \ldots \ldots \ldots \ldots \ldots$ & SE & 0.60 \\
\hline Gas Water Heater (Space Heating). . . . . . . . . . & AFUE & 0.75 \\
\hline$\ldots \ldots \ldots \ldots \ldots \ldots \ldots \ldots$ & HSPF & 3.413 \\
\hline Electric Radiant $\ldots \ldots \ldots \ldots \ldots \ldots \ldots \ldots$ & HSPF & 3.413 \\
\hline Heat Pump Water Heater (Space) . . . . . . . . . . . & HSPF & 5.11 \\
\hline Electric Water Heater $($ Space $) \ldots \ldots \ldots \ldots$ & HSPF & 2.73 \\
\hline \multicolumn{3}{|l|}{ Cooling: } \\
\hline Electric Evaporative Cooling & EER & 30 \\
\hline Gas Absorption Cooler & COP & 0.40 \\
\hline \multicolumn{3}{|l|}{ Water Heating: } \\
\hline$\ldots \ldots \ldots \ldots \ldots \ldots \ldots \ldots \ldots \ldots$ & $\mathrm{COP}$ & 2.00 \\
\hline Instantaneous Electric $\ldots \ldots \ldots \ldots \ldots \ldots$ & $\mathrm{EF}$ & 0.87 \\
\hline Instantaneous Gas & $\mathrm{EF}$ & 0.75 \\
\hline Solar (Use SRCC Adjustment Procedures) & $\mathrm{EF}$ & 2.00 \\
\hline
\end{tabular}

\section{Operating condition assumptions.}

a. Alternate operating conditions assumptions shall only be used where authorized by state law or regulation. Alternate operating condition assumptions shall be applied equally to both the Reference Home and the Rated Home and shall be consistent for all HERS providers operating within the state.

b. All HERS providers shall estimate the annual purchased energy consumption for heating, cooling and hot water for both the Rated Home and the Reference Home using the following assumptions-

(1) Temperature control set points for heating and cooling of $68^{\circ} \mathrm{F}$ and $78^{\circ} \mathrm{F}$, respectively;

(2) Where programmable offsets are available in the Rated Home, $5^{\circ} \mathrm{F}$ temperature control point offsets with an 11 p.m. to 7 a.m. schedule for heating and a 9 a.m. to 3 p.m. schedule for cooling, and with no offsets assumed for the Reference Home; 
(3) Internal heat gains from lights, people and equipment of 72,000 Btu/day for detached homes and 36,000 Btu/day for attached homes;

(4) When calculating annual purchased energy for cooling, internal latent gains assumed as 0.20 times sensible internal heat gains; Estimated hot water usage based on Equation 7.

\section{Equation 7: Gallons/day $=\mathbf{3 0}$ gallons $+(10$ gallons* number of bedrooms).}

(6) The climatologically most representative TMY or equivalent climate data, which may be interpolated between climate sites if interpolation is established or approved by the accrediting body and consistent for all HERS providers operating within a state.

(7) Corrections for climate conditions and mis-sizing of equipment, using correction factors to HSPF, SEER and AFUE that are established or approved by the accrediting body and consistent for all HERS providers operating within a state.

(8) Local residential energy or utility rates that-

(a) Are revenue-based and include customer service and fuel charges;

(b) Are updated at least annually; and

(c) Are confirmed by the accrediting body.

7. Non-rated energy consuming devices. Consistent with Section B.3.a.(3) and (4) of these Guidelines all HERS providers shall calculate and report the annual purchased energy consumption and energy cost for the operation of all non-rated energy consuming devices in the Rated and Reference Homes. Actual efficiency of these devices is not considered and usage estimates are based on Table 10. The data in Table 10 may be modified if they are established or approved by the accrediting body consistent for all HERS providers operating within the state. 
TABLE 10.-Annual Energy Use for Non-Rated Features

\begin{tabular}{|c|c|c|c|}
\hline End use & Units/year & Energy estimate & Applicability \\
\hline Ceiling Fan & $\mathrm{kWh}$ & 220/ea & If present. \\
\hline Dishwasher & $\mathrm{kWh}$ & $\begin{array}{l}\text { 299/per cooking } \\
\text { area }\end{array}$ & $\begin{array}{l}\text { If present, or if space is dedicated for } \\
\text { DW. }\end{array}$ \\
\hline Dryer, electric & $\mathrm{kWh}$ & $875 /$ ea & $\begin{array}{l}\text { If present, or if } 220 \mathrm{~V} \text { wiring is } \\
\text { present @ dryer location }\end{array}$ \\
\hline Dryer, gas & $\begin{array}{l}\text { Therms } \\
\mathrm{kWh}\end{array}$ & $\begin{array}{l}60 / \text { ea } \\
100 / \text { ea }\end{array}$ & $\begin{array}{l}\text { If present, or if gas piping is present } \\
\text { @ dryer location. a }\end{array}$ \\
\hline Lights & $\mathrm{kWh}$ & 940 & All homes. \\
\hline $\begin{array}{l}\text { Microwave Oven-built- } \\
\text { in }\end{array}$ & $\mathrm{kWh}$ & $\begin{array}{l}\text { 191/per cooking } \\
\text { area }\end{array}$ & If permanently installed. \\
\hline $\begin{array}{l}\text { Miscellaneous Plug } \\
\text { Loads }\end{array}$ & $\mathrm{kWh}$ & 500 & All homes. \\
\hline Pool Pump & $\mathrm{kWh}$ & $1700 /$ ea & If present \\
\hline $\begin{array}{l}\text { Range/Oven Combo- } \\
\text { electric }\end{array}$ & $\mathrm{kWh}$ & $\begin{array}{l}450 / \text { per cooking } \\
\text { area }\end{array}$ & $\begin{array}{l}\text { If present, or if } 220 \mathrm{~V} \text { wiring is } \\
\text { present } @ \text { range location. }\end{array}$ \\
\hline $\begin{array}{l}\text { Range/Oven Combo- } \\
\text { gas w/pilot }\end{array}$ & Therms & 44/per cooking area & $\begin{array}{l}\text { If present, or if gas piping is present } \\
\text { (a) range location }\end{array}$ \\
\hline $\begin{array}{l}\text { Range/Oven Combo- } \\
\text { gas w/o pilot }\end{array}$ & Therms & $22 /$ per cooking area & If present. \\
\hline Refrigerator & $\mathrm{kWh}$ & 1150 & Each one present. \\
\hline Television & $\mathrm{kWh}$ & 720 & All homes. \\
\hline Washer, clothes & $\mathrm{kWh}$ & 99/ea & $\begin{array}{l}\text { If present, or facilities present for } \\
\text { washer. }\end{array}$ \\
\hline Well pump & $\mathrm{kWh}$ & 288/ea & If present. \\
\hline
\end{tabular}

\section{Projected Ratings for to-be-built or to-be-improved homes.}

a. A HERS provider may calculate the Projected Rating of a to-be-built or to-beimproved home based on architectural drawings with material, mechanical and electrical specifications for a to-be-built home, or based on a site audit for a to-beimproved home; and by:

(1) Using either the envelope leakage rate specified as the required performance by the construction documents, the site-measured envelope leakage rate, or a default value for normalized leakage of $\mathrm{nL}=0.67$, where $\mathrm{nL}$ may be converted to an air change rate using Equation 6 of Section B.4.a(19) to compute average annual air changes per hour(ach);

(2) Using either the distribution system efficiency specified as the required performance by the construction documents, the site-measured distribution system efficiency, or a default distribution system efficiency value from Table 6; and 
Using the planned location and orientation of the proposed home, or if the proposed orientation is unknown, calculating ratings for the home facing each of the four cardinal directions, north, south, east and west, and using the lowest rating score as the Projected Rating.

b. Upon completion of construction and verification of the proposed specifications, all rated features of the home shall be confirmed using site inspections and envelope air leakage rates and distribution system efficiencies derived from onsite diagnostic tests conducted in accordance with Section B.5.e.(1) of this Guideline, and the actual orientation of the home.

\section{ADMINISTRATION OF A HOME ENERGY RATING SYSTEM}

\section{Energy analysis tool requirements.}

a. In order to be certified for the purpose of providing home energy ratings under these Guidelines, an energy analysis (rating) tool must:

(1) Demonstrate the ability to calculate annual purchased energy consumption for each building type which ratings are provided;

(2) Estimate the total annual purchased energy consumption associated with minimum rated features set forth in Section B.5 of these Guidelines;

(3) Calculate energy use of non-rated energy consuming devices set forth in Section B.7 of these Guidelines;

(4) Reflect the operating condition assumptions described in Section B.6 of these Guidelines; and

(5) Pass all tests in Tier 1 and Tier 2 of the Home Energy Ratings System Building Energy Simulation Test (HERS BESTEST)-NREL Report no. NREL/TP-472-7332 which is administered by, and has pass-fail criteria set by the accrediting body.

b. Future guideline requirements. On or before September 30, 2003, all HERS providers accredited under these Guidelines, shall have updated their energy analysis tool to be capable of rating the following additional features-

(1) Thermostat set-back and set-up;

(2) Effects of part load and weather conditions on HVAC systems;

(3) Demand and time of use utility rates;

(4) Solar water heating;

(5) Sunspaces; and

(6) Whole house fans.

c. Energy analysis tools certified under paragraph (a)(5) of this section must be retested and recertified if a new version of the tool is released that includes changes to the engineering algorithms.

2. Site data collection manual. All HERS providers shall provide data collectors with a manual containing procedures for the on-site collection of data that are:

a. Consistent with those provided in Appendix A as extracted from Guideline No. 10 of the Home Energy Rating Systems Council Guidelines;

b. Established or approved by the Accrediting Body and updated as supplemental or revised information becomes available. 
3. Training home energy raters. Each person seeking a position as a full rater, data collector, or data analyst for any HERS provider shall receive training by an accredited rater training organization prior to performing rating tasks without supervision. The training shall be conducted in accordance with a syllabus developed by all HERS providers. The syllabus must specify subjects applicable to each position (i.e., rater, data collector or data analyst) and must include-

a. Classroom training. Each rater shall receive classroom training on-

(1) Basic principles of building science (i.e., viewing the home as a system);

(2) Thermal resistance of insulation materials

(3) The minimum rated features for buildings;

(4) Blower door testing procedures

(5) Duct leakage testing procedures

(6) Variations in construction types and their ramifications;

(7) Types and efficiencies of windows;

(8) Types and efficiencies of heating, cooling, water heating, and lighting systems;

(9) Types and characteristics of space conditioning and domestic hot water distribution systems;

(10) Types of thermostatic controls;

(11) Determination of azimuth;

(12) Determination of air leakage;

(13) Determination of fuels used by major appliances;

(14) Utility rate structures;

(15) On-site inspection procedures;

(16) Producing a scaled and dimensioned drawing of a home;

(17) Calculating the area of rectangles, triangles, circles, ovals and combinations of these shapes;

(18) Calculating the volume of boxes, pyramids, spheres, and other geometric shapes;

(19) Completing a home energy rating checklist or entering data into a home energy rating software program;

(20) Completing a home energy improvement analysis or entering data into a home energy rating software program that performs improvement analysis;

(21) Basic knowledge of financial incentive programs and energy efficient mortgages;

(22) Communicating the benefits of energy saving measures and practices to the consumer; and

(23) Quality assurance.

b. Written examination. Each rater shall be given a written examination that evaluates the rater's understanding of the subjects in paragraph (a) of this section.

c. Field training. Each rater shall perform two ratings (or portions of ratings for those seeking to be data collectors or data analysts), including software operations, in the presence of trainers.

d. Probationary period. Each rater shall complete a probationary period where close supervision is provided. This period covers a minimum of five ratings, after which the supervisor shall determine if additional training is needed.

e. Challenge test. A challenge test may be taken, which, if passed in all competencies, will waive the classroom training requirement. The requirements of paragraphs (c) and (d) of this section may not be waived.

f. Continuing education. Each rater shall complete a minimum of 12 hours of approved continuing education during each 3-year period of certification. 


\section{Quality control.}

a. All HERS providers shall establish a quality assurance plan that includes-

(1) Periodic peer review and reevaluation of raters;

(2) Random auditing of each rater's work;

(3) Evaluation of the training program by raters after field experience;

(4) Customer evaluation of rating services;

(5) Random review of the inputs into the rating tool to ensure that they are consistent with the data collected in the field; and

(6) Verification of the accuracy and completion of the input forms and output of the first five ratings performed by each rater.

b. All HERS providers shall maintain a permanent quality assurance file that is updated at least every two years or when changes to the system are made, and contains:

(1) A description of local rate structure for electricity, gas and other locally used fuels;

(2) A description of climatological data (including interpolation methods) used;

(3) A description of the data storage and maintenance systems including:

(a) Software for data base,

(b) Training for data entry personnel, and

(c) Data quality assurance procedures that will be exercised;

(4) A description of each rating tool that the HERS provider uses including a list of which home types the tool supports;

(5) The results and date of the certified accuracy test conducted for the rating tool;

(6) An example of the rating outputs produced;

(7) The materials and tests used to provide training for home energy raters;

(8) The materials used to document the site data collection procedures; and

(9) A description of the individual elements of the quality assurance plan set forth in paragraph (a) of this section.

c. All HERS providers shall maintain an electronic database of information for each home rated. The minimum content of the database is -

(1) A unique file reference of ID number;

(2) Date of on-site inspection;

(3) Raters name;

(4) Tool name and version:

(5) Identification of climate data used for the rating;

(6) Type of rating, either projected or confirmed:

(7) Use of rating, either -

(a) Time of sale rating;

(b) Pre-home improvement rating;

(c) Post home improvement rating; or

(d) Information only rating;

(8) Address of Rated Home;

(9) Home type;

(10) Floor area of conditioned space;

(11) Fuel types used by building heating, cooling and water heating systems;

(12) Minimum rated feature energy efficiency data used to determine the rating; 
(13) In the four categories of heating, cooling, water heating and all other uses, the -

(a) Estimated annual purchased energy consumption in total;

(b) Estimated annual purchased energy consumption by fuel;

(c) Estimated annual energy costs in total; and

(d) Estimated annual energy cost by fuel.

(14) Estimated total annual energy cost for all uses; and

(15) Rating score of the Rated Home on 0-100 points scale and 1-5+ stars category

(16) To extent allowed by state statute, all HERS providers shall for $10 \%$ or for 500 of the homes rated annually, whichever is less, maintain a database of the following -

(a) Homeowners authorization for the release of consumption information by utility companies;

(b) Climate data site used for energy estimation;

(c) Any energy efficiency improvements made to the home and date of completion.

\section{Guideline compliance.}

a. Full accreditation. Any HERS provider may be accredited as being in full compliance with these Guidelines if it demonstrates that it can -

(1) Conducts ratings in accordance with the provisions of Section B.1 of these Guidelines;

(2) Reports the results of ratings in accordance with the provisions of Section B.3 of these Guidelines;

(3) Produces documentation of a correctly configured Reference Home in accordance with the provisions of Section B.4 of these Guidelines;

(4) Provides documentation that their energy analysis tool is certified in accordance with the Accreditation Procedures as having passed HERSBESTEST.

(5) Provides training in accordance with the provisions of Section C.3 of these Guidelines;

(6) Provides documentation of a quality control plan and a permanent quality assurance file in accordance with the provisions of Section C.4 of these Guidelines;

(7) Provides documentation of a monitoring and evaluation program in accordance with the provisions of Section C.5 of these Guidelines;

b. Basic compliance. Any exiting HERS provider may be accredited for a period of up to two years, as being in basic compliance with these Guidelines, by demonstrating that it meets all the provisions of paragraph (a) of this section except that it may -

(1) Use a simplification of utility rate structures;

(2) Rate only the features set forth by Section B.5 of these Guidelines, that may be rated with its existing system capabilities;

(3) Use only those standard operating conditions set forth in Section B.6 of these Guidelines that can be handled by their existing energy analysis tool;

(4) Pass only the Tier 1 set of HERS-BESTEST tests; 
(a) Verification that each person with responsibilities in the conduction of ratings has completed classroom training on all items set forth in Section C.3.a of these Guidelines;

(b) Verification that each person with responsibilities for the conduction of ratings has received field training;

(c) Verification that all personnel have successfully passed a written objective examination in all areas applicable to their designated job descriptions; and

(d) Verification of a probationary period set forth in Section C.3.d of these Guidelines; and

\section{Accreditation.}
(6) Use an existing program to monitor and evaluate the accuracy of ratings.

a.

All HERS providers operating in voluntary compliance with these Guidelines shall be accredited only by a State or by an other independent Accrediting Body authorized by the state to:

(1) establish and coordinate consistent adjustments to these Guidelines within a State for -

(a) default values for minimum rated features set forth in Section B.5 of these Guidelines;

(b) operating condition assumptions and local climatic data interpolation set forth in Section B.6 of these Guidelines;

(c) alternate standard operating condition assumptions set forth in Section B.5 of these Guidelines.

(2) administer the procedures for certification of energy analysis tools established by HERS-BESTEST set forth in the NREL Report No. NREL/TP-472-7332 referenced in Section C.1 of these Guidelines; these Guidelines; review and evaluate the quality control procedures set forth in Section C.4 of these Guidelines; and evaluate the site data collection manual and monitoring and evaluation program set forth in Sections C.2 and C.5 of these Guidelines.

b. The accreditation process shall be conducted fully consistent with the "Mortgage Industry National Accreditation Procedures for Home Energy Rating Systems" and with applicable state law, included but not limited to statutes and regulation related to home energy rating systems and to the state's required administrative procedures. In cases where the national Accreditation Procedures and state law or regulation differ, the state law or regulation shall govern.

c. Any Lender or agency in a mortgage business who offers mortgage or loan incentives for energy efficiency on the basis of a home energy rating should require that such ratings be conducted in accordance with these Guidelines and that the rating provider is accredited in accordance with the "Mortgage Industry National Accreditation Procedures for Home Energy Rating Systems." 


\section{REVISION OF TECHNICAL GUIDELINES}

\section{Periodic review of technical Guidelines}

At least triennially, the provisions set forth in these Technical Guidelines shall be reviewed by the Buildings Committee of NASEO in collaboration with other stakeholders. At a minimum, this review shall include consideration and evaluation of changes in the law, technological innovations, and comments received from interested parties.

\section{Submission of proposals to change Technical Guidelines:}

a. Proposals to change these Technical Guidelines may be submitted in writing, at any time, to NASEO.

b. All proposals to change that meet the criteria set forth in this section of these procedures shall be accepted for consideration and evaluation.

c. Proposals to change these Technical Guidelines shall include the following:

(1) Identification of the proposal to change, including the following minimum information:
(a) Proponent(s) full name(s),
(b) Organizational affiliation(s) or representation(s),
(c) Full mailing address(es),
(d) Daytime phone number(s),
(e) Signature of primary proponent, and
(f) Date

(2) Specific revisions to the Technical Guidelines in a format that clearly identifies the manner in which the Technical Guidelines are to be altered (ie. underline/strikeout format or equivalent). Any proposal to change that does not include proposed alteration(s) shall be rejected and returned to the proponent.

(3) Substantive reason(s) or justification for each proposed change. The lack of substantive justification for a proposed change may result in the return of the proposals to change to the proponent(s).

(4) Supporting documentation that may be needed for the reasoned evaluation of the proposal.

d. Proposals to change these Technical Guidelines shall be considered and evaluated at least annually.

(1) The effective date of any annual revisions to these Technical Guidelines shall be January 1 .

(2) Only those proposals to change that are received on or prior to the last working day of April shall be considered for the revisions to these technical Guidelines that may become effective on January 1 of the following year.

\section{Public Review Process}

a. Revisions to these Technical Guidelines shall occur only after the relevant proposals to change have been subjected to public scrutiny and comment using the following review process:

(1) The National Association of State Energy Officials shall appoint a Technical Guidelines Revision Advisory Committee. This Committee shall be responsible for conducting the periodic evaluation and the annual evaluation of proposals to change through a consensus process, whereby both consenting and the non-consenting opinions are documented and incorporated as comments into each report or proposal to change.

(2) Following initial evaluation by the Technical Guidelines Revision Advisory Committee, proposals to change shall be posted on the appropriate Internet web pages for a period of not less than 30 days during which public comment shall be accepted. 
(3) Following the public comment period, the Technical Guidelines Revision Advisory Committee shall meet to reconcile public comments with the initial comments of the Committee and, if changes are determined necessary, a final set of recommended changes with consensus comments that considers public comments shall be prepared on each proposal for change.

(4) Proposals for change receiving two-thirds majority support from the Technical Guidelines Revision Advisory Committee after public comment shall be incorporated into a set of revised Technical Guidelines.

b. The revised Technical Guidelines shall be published on the appropriate Internet web pages and submitted to the NASEO Building Committee not later than the end of July each year in which changes are recommended. 


\section{Appendix B. Standard Reference House Definitions}

Several reference sources provide guidance on defining standard construction practices, including the Model Energy Code (MEC 1995), International Energy Conservation Code (IECC 1998), National Home Energy Rating System (HERS) Technical Guidelines, and ASHRAE Standard 90.2. As of October 1999, at least 31 states and the District of Columbia had adopted IECC 1998/2000 or its predecessor, the Model Energy Code, on a statewide basis ${ }^{1}$. The technical guidelines developed for HERS by the National Association of State Energy Officials include additional specifications for equipment sizing, envelope U-values, and daylighting not included in the Model Energy Code. MEC 1995 / IECC 1998 and HERS guidelines are outlined in the table below.

\begin{tabular}{|c|c|}
\hline MEC 1995 / IECC 1998 & Home Energy Rating System \\
\hline $\begin{array}{l}\text { - May use either prescriptive component-based } \\
\text { approach or flexible performance-based approach } \\
\text { - Modeling is required to compare annual energy } \\
\text { use of proposed house with standard design (tool } \\
\text { approved by local building official) } \\
\text { - Renewable energy use excluded from annual } \\
\text { energy use for proposed house } \\
\text { - Operating conditions for both houses } \\
\text { - Thermostat set points: } 68^{\circ} \mathrm{F} \text { for heating ( } 60^{\circ} \mathrm{F} \\
\text { set back for } 7 \text { hours) and } 78^{\circ} \mathrm{F} \text { for cooling } \\
\text { - } 1500 \text { Btu/hr internal heat gain } \\
\text { - Air distribution loss factors: } 75 \% \text { for heating } \\
\text { and } 80 \% \text { for cooling } \\
\text { - TMY weather data from closest location } \\
\text { - Features of "standard design" } \\
\text { - Limits total U-value of wall system (walls, } \\
\text { doors, windows) based on climate } \\
\text { - Specifies upper limits for U-value of other } \\
\text { components (e.g., roof, foundation) } \\
\text { - Same surface areas, volume, glazing area, } \\
\text { mechanical equipment, and foundation design } \\
\text { as proposed design } \\
\text { - Equal glazing area in all four orientations } \\
\text { - No exterior window shading except overhangs, } \\
\text { but drapes assumed during air-conditioning } \\
\text { season } \\
\text { - Same proportion of ductwork outside } \\
\text { conditioned space as proposed design } \\
\text { - Air infiltration equals } 0.50 \text { ACH (annual avg.) } \\
\text { - Internal mass equals } 8 \text { lb/ft }{ }^{2} \text { and structural mass } \\
\text { equals } 3.5 \text { lb/ft }{ }^{2} \text { (undefined heat capacity) } \\
\text { - Specifies minimum efficiencies for } \\
\text { heating/cooling/hot-water equipment }\end{array}$ & $\begin{array}{l}\text { - Provides rating using a 100-point scale (reference home } \\
\text { rated } 80 \text { by definition) } \\
\text { - Used to determine ENERGY STAR }{ }^{\circledR} \text { compliance (HERS } \\
\text { rating of more than } 86 \text { required) } \\
\text { - Relative energy consumption of Rated Home calculated } \\
\text { using normalized Modified End Use Loads method } \\
\text { - Modeling tool must pass HERS BESTEST } \\
\text { - Renewable energy not included in "purchased energy" } \\
\text { - Operating conditions for both houses same as MEC } 95 \\
\text { except: } \\
\text { - No thermostat set back in reference home } \\
\text { - } 72,000 \text { Btu/day internal sensible heat gain } \\
\text { - } 14,400 \text { Btu/day latent heat gain } \\
\text { - TMY weather data from location most climatologically } \\
\text { representative } \\
\text { - Features of reference home same as MEC } 95 \text { “standard } \\
\text { design" except: } \\
\text { - Specifies wall U-value based on MEC } 93 \\
\text { - Fixed UA value and orientation of doors } \\
\text { - Glazing area equal to } 18 \% \text { of conditioned floor area with } \\
\text { equal areas in each orientation } \\
\text { - Specifies window shading coefficients ( } 0.7 \text { in summer } \\
\text { and } 0.88 \text { during other seasons) and frame factor (27\%) } \\
\text { - No exterior shading from overhangs } \\
\text { - HVAC equipment efficiencies defined as minimum } \\
\text { NAECA standard } \\
\text { - HVAC equipment sizing in accordance with standard } \\
\text { practice } \\
\text { - } 80 \% \text { distribution efficiency for air and } 95 \% \text { for hydronic } \\
\text { systems } \\
\text { - Specifies solar absorptivity of opaque areas } \\
\text { - Air infiltration = } 0.57 \bullet \text { W (where W is a weather factor } \\
\text { from ASHRAE Standard } 136 \text { ) } \\
\text { construction }\end{array}$ \\
\hline
\end{tabular}

Note: For acronyms and abbreviations listed above, please see the List of Terms on page vi

\footnotetext{
${ }^{1}$ Building Codes Assistance Project (BCAP), "Model Energy Code and State Adoption," http://www.bcapenergy.org/mecchart.html.
} 


\section{Appendix C. Performance Analysis Examples}

NREL has conducted several detailed energy performance simulations using DOE-2.2 over the past few years. Three examples are presented here to further illustrate the process described in this document: Pulte Homes Tucson, Venture Homes - Atlanta, and Mitchell Homes - Pensacola.

\section{Pulte Homes in Tucson, Arizona}

The following is an analysis of the Building America prototype house built in Tucson by Pulte Homes with design assistance from the Building Science Consortium (BSC) team. The analysis starts with the description of the Building America house with energy features consistent with builder st andard practice, and incrementally adds features until the prototype house is simulated.

DOE-2.2 and PowerDOE were used to simulate the hourly energy use of the test homes. Figures C-1 and C-2 show the building envelope as modeled in eQuest.

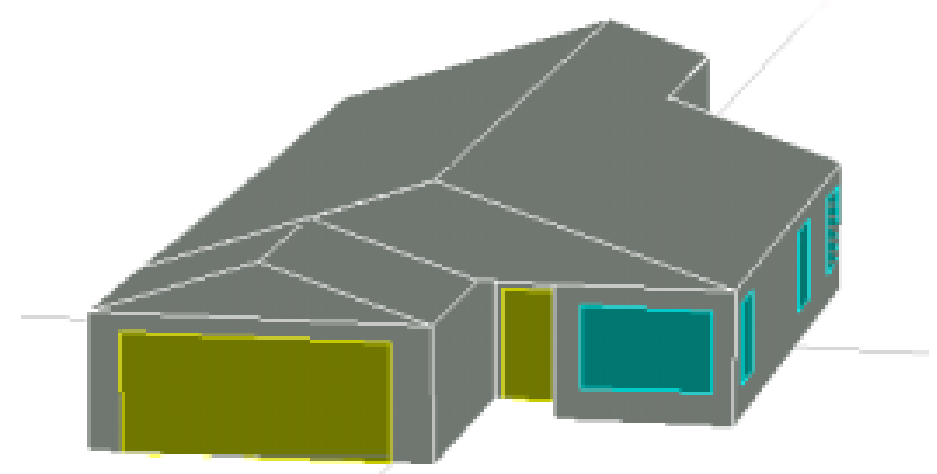

Figure C-1. Front of test house (shading not included). (Image captured from eQUEST.) 


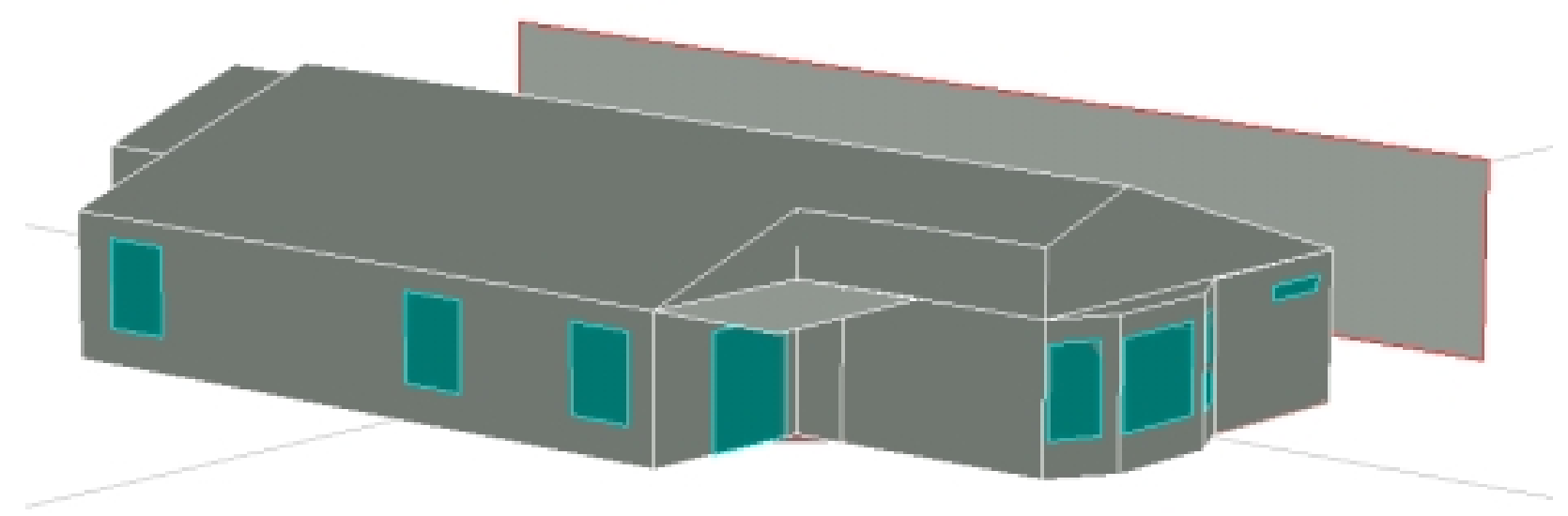

Figure C-2. Side and back of test house, including porch and nearby shading. (Image captured from eQUEST.)

\section{Common Features}

Test data was used to establish many of the inputs to the models, such as infiltration rates, $\mathrm{A} / \mathrm{C}$ performance, and attic performance. The models were then modified to better capture "typical" occupant behavior and house operation over a full year.

Features common to all of the building simulations:

- Shading from nearby building and patio shading (see Figure C-2).

- Use of interior blinds and draperies:

- Half of all windows are assumed to be covered at all times.

- When shades/draperies are used, the window R-value is increased by 1.0 .

○ When shades/draperies are used, the shading coefficient is reduced by $40 \%$.

- Supply flow rate of 350 CFM per ton of cooling. This is the average of the measured data.

\section{Incremental Measures}

Table C-1 presents a summary of results for a series of simulations. This series starts with the builder standard practice building description and adds measures one at a time until the building complies with the Building America specifications. The order in which the measures are added to the building model was determined by a number of issues. First, the local builder was also building a number of houses that meet the Energy Star requirements. These houses have 2-in. x 6-in. walls, vinyl frame windows, and SEER 12 air-conditioning units. These measures were added first so that a comparison of the Building America house with the Energy Star house can be made. From the Energy Star model (increment 3, described below), measures that have a negative or zero capital cost were added first, and then measures were added that had the highest benefit-to-cost ratio. 
Table C-1. Summary of results, space heating, cooling, and DHW

\begin{tabular}{|c|c|c|c|c|c|c|c|c|c|c|c|c|c|}
\hline \multirow[b]{3}{*}{ increment } & \multirow{3}{*}{$\begin{array}{c}\mathrm{Htg} / \mathrm{Clg} \\
\mathrm{kWh}\end{array}$} & \multirow{3}{*}{$\begin{array}{l}\text { Heating } \\
\text { therms }\end{array}$} & \multicolumn{3}{|c|}{ Source Energy } & \multicolumn{6}{|c|}{ Energy Cost } & \multirow{2}{*}{\multicolumn{2}{|c|}{$\begin{array}{c}\text { fraction of time } \\
\text { space temp }>80 F\end{array}$}} \\
\hline & & & \multirow{2}{*}{\begin{tabular}{|c|}
$\mathrm{Htg}$ \\
MBTU/yr
\end{tabular}} & \multirow{2}{*}{$\begin{array}{c}\mathrm{Clg} \\
\mathrm{MBTU} / \mathrm{yr}\end{array}$} & \multirow{2}{*}{$\begin{array}{c}\text { Savings } \\
(\%)\end{array}$} & \multirow{2}{*}{\multicolumn{2}{|c|}{$\begin{array}{c}\mathrm{Htg} / \mathrm{Clg} \\
\$ / \mathrm{yr}\end{array}$}} & \multirow{2}{*}{$\begin{array}{c}\text { Savings } \\
(\%)\end{array}$} & \multirow{2}{*}{\multicolumn{2}{|c|}{$\begin{array}{l}\begin{array}{l}\text { Measure } \\
\text { value }(\$ / \mathrm{yr})\end{array} \\
\end{array}$}} & \multirow{2}{*}{$\begin{array}{l}\text { Package } \\
\text { savings } \$ / y\end{array}$} & & \\
\hline & & & & & & & & & & & & Main Zone & Any Zone \\
\hline Base (Bldr Std Practice) & 5462 & 236 & 24.9 & 65.7 & & $\$$ & 782 & & & & & $0.0 \%$ & $0.9 \%$ \\
\hline Base + incr. Insulation & 5099 & 225 & 23.6 & 61.4 & $6 \%$ & $\$$ & 735 & $6 \%$ & $\$$ & 47.3 & 47 & $0.0 \%$ & $1.0 \%$ \\
\hline Base + vinyl frames & 4810 & 211 & 22.1 & 58.0 & $12 \%$ & $\$$ & 692 & $12 \%$ & $\$$ & 42.8 & 90 & $0.0 \%$ & $0.9 \%$ \\
\hline $\begin{array}{l}\text { Base + } 12 \text { SEER } \\
\text { (Energy Star) }\end{array}$ & 4040 & 211 & 22.1 & 48.7 & $22 \%$ & $\$$ & 615 & $21 \%$ & $\$$ & 77.0 & 167 & $0.0 \%$ & $0.9 \%$ \\
\hline E-Star +4 to 3 tons & 4121 & 211 & 22.1 & 49.7 & $21 \%$ & $\$$ & 623 & $20 \%$ & $\$$ & $(8.1)$ & $\$ 159$ & $0.0 \%$ & $1.0 \%$ \\
\hline E-Star + 24" o.c. & 4106 & 210 & 22.0 & 49.5 & $21 \%$ & $\$$ & 621 & $21 \%$ & $\$$ & 2.5 & $\$ 162$ & $0.0 \%$ & $1.0 \%$ \\
\hline E-Star +PPG1000 & 2950 & 204 & 21.3 & 35.5 & $37 \%$ & $\$$ & 499 & $36 \%$ & $\$$ & 121.6 & $\$ 283$ & $0.0 \%$ & $0.0 \%$ \\
\hline E-Star + Unv Roof & 2648 & 215 & 22.5 & 31.7 & $40 \%$ & $\$$ & 480 & $39 \%$ & $\$$ & 19.2 & $\$ 302$ & $0.0 \%$ & $0.0 \%$ \\
\hline E-Star + AFUE 93 & 2648 & 203 & 21.3 & 31.7 & $42 \%$ & $\$$ & 468 & $40 \%$ & $\$$ & 12.0 & $\$ 314$ & $0.0 \%$ & $0.0 \%$ \\
\hline E-Star +3 to 2 ton & 2689 & 203 & 21.3 & 32.1 & $41 \%$ & $\$$ & 472 & $40 \%$ & $\$$ & (4.1) & $\$ 310$ & $0.0 \%$ & $0.0 \%$ \\
\hline E-Star + DHW EF62 & 2689 & 189 & 19.9 & 32.1 & $43 \%$ & $\$$ & 458 & $41 \%$ & $\$$ & 14.0 & $\$ 324$ & $0.0 \%$ & $0.0 \%$ \\
\hline E-Star + SEER 10 & 3187 & 189 & 19.9 & 38.2 & $36 \%$ & $\$$ & 508 & $35 \%$ & $\$$ & (49.8) & $\$ 274$ & $0.0 \%$ & $0.0 \%$ \\
\hline
\end{tabular}

If DHW is not included in the analysis, the savings fractions are somewhat higher, because the vast majority of savings are from non-DHW measures. Table $\mathrm{C}-2$ presents the same table without DHW values included. 
Table C-2. Summary of results, space heating and cooling only

\begin{tabular}{|c|c|c|c|c|c|c|c|c|c|c|c|c|c|}
\hline \multirow[b]{3}{*}{ increment } & \multirow{3}{*}{$\begin{array}{c}\mathrm{Htg} / \mathrm{Clg} \\
\mathrm{kWh}\end{array}$} & \multirow{3}{*}{$\begin{array}{l}\text { Heating } \\
\text { therms }\end{array}$} & \multirow{2}{*}{\multicolumn{3}{|c|}{ Source Energy }} & \multirow{2}{*}{\multicolumn{6}{|c|}{ Energy Cost }} & \multirow{2}{*}{\multicolumn{2}{|c|}{$\begin{array}{c}\text { fraction of time } \\
\text { space temp > 80F }\end{array}$}} \\
\hline & & & & & & & & & & & & & \\
\hline & & & \begin{tabular}{|c|}
$\mathrm{Htg}$ \\
$\mathrm{MBTU} / \mathrm{yr}$ \\
\end{tabular} & $\begin{array}{c}\mathrm{Clg} \\
\mathrm{MBTU} / \mathrm{yr}\end{array}$ & $\begin{array}{c}\text { Savings } \\
(\%)\end{array}$ & \multicolumn{2}{|c|}{$\begin{array}{c}\mathrm{Htg} / \mathrm{Clg} \\
\$ / \mathrm{yr}\end{array}$} & $\begin{array}{c}\text { Savings } \\
(\%)\end{array}$ & \multicolumn{2}{|c|}{$\begin{array}{l}\text { Measure } \\
\text { value }(\$ / y r)\end{array}$} & $\begin{array}{l}\text { Package } \\
\text { savings } \$ / y\end{array}$ & Main Zone & Any Zone \\
\hline Base (Bldr Std Practice) & 5462 & 94 & 10.4 & 65.7 & & $\$$ & 640 & & & & & $0.0 \%$ & $0.9 \%$ \\
\hline Base + incr. Insulation & 5099 & 83 & 9.2 & 61.4 & $7 \%$ & $\$$ & 593 & $7 \%$ & $\$$ & 47.3 & 47 & $0.0 \%$ & $1.0 \%$ \\
\hline Base + vinyl frames & 4810 & 69 & 7.6 & 58.0 & $14 \%$ & $\$$ & 550 & $14 \%$ & $\$$ & 42.8 & 90 & $0.0 \%$ & $0.9 \%$ \\
\hline $\begin{array}{l}\text { Base + } 12 \text { SEER } \\
\text { (Energy Star) }\end{array}$ & 4040 & 69 & 7.6 & 48.7 & $26 \%$ & $\$$ & 473 & $26 \%$ & $\$$ & 77.0 & \$ 167 & $0.0 \%$ & $0.9 \%$ \\
\hline E-Star +4 to 3 tons & 4121 & 69 & 7.6 & 49.7 & $25 \%$ & $\$$ & 481 & $25 \%$ & $\$$ & $(8.1)$ & \$ 159 & $0.0 \%$ & $1.0 \%$ \\
\hline E-Star + 24" o.c. & 4106 & 68 & 7.5 & 49.5 & $25 \%$ & $\$$ & 479 & $25 \%$ & $\$$ & 2.5 & \$ 162 & $0.0 \%$ & $1.0 \%$ \\
\hline E-Star +PPG1000 & 2950 & 62 & 6.8 & 35.5 & $44 \%$ & $\$$ & 357 & $44 \%$ & $\$$ & 121.6 & $\$ 283$ & $0.0 \%$ & $0.0 \%$ \\
\hline E-Star + Unv Roof & 2648 & 73 & 8.0 & 31.7 & $48 \%$ & $\$$ & 338 & $47 \%$ & $\$$ & 19.2 & $\$ 302$ & $0.0 \%$ & $0.0 \%$ \\
\hline E-Star + AFUE 93 & 2648 & 61 & 6.8 & 31.7 & $49 \%$ & $\overline{\$}$ & 326 & $49 \%$ & $\$$ & 12.0 & $\$ 314$ & $0.0 \%$ & $0.0 \%$ \\
\hline E-Star +3 to 2 ton & 2689 & 61 & 6.9 & 32.1 & $49 \%$ & $\$$ & 330 & $48 \%$ & $\$$ & (4.1) & $\$ 310$ & $0.0 \%$ & $0.0 \%$ \\
\hline E-Star + DHW EF62 & 2689 & 61 & 6.9 & 32.1 & $49 \%$ & $\$$ & 330 & $48 \%$ & $\$$ & - & $\$ 310$ & $0.0 \%$ & $0.0 \%$ \\
\hline E-Star + SEER 10 & 3187 & 61 & 6.9 & 38.2 & $41 \%$ & $\$$ & 380 & $41 \%$ & $\$$ & (49.8) & $\$ 260$ & $0.0 \%$ & $0.0 \%$ \\
\hline
\end{tabular}

\section{- Base Case (increment 0)}

The base case, or starting point, for the analysis is based on a new prototype house designed and built by Pulte Homes in Tucson on lot 580 of the Retreat at the Bluffs development. This house was built to the Building America design. The energy features of this house are "degraded" to builder standard practice, as described in the Building Science Corporation memo of July 27, 1999.

$\begin{array}{ll}\text { Features: Ceiling } & \text { R-30 flat attic vented } \\ \text { Walls } & \text { R-13 16 in. o.c. + R-4 EPS exterior } \\ & \text { R-13 16 in. o.c. to garage } \\ \text { Foundation } & \begin{array}{l}\text { Slab, uninsulated } \\ \text { metal frame, double-glazed }\end{array} \\ \text { Windows } & \text { U=0.87, SHGC }=0.73 \\ & 0.35 \mathrm{ACH} \\ \text { Infiltration } & 80 \% \mathrm{AFUE} \text { furnace in vented attic } \\ \text { Heating system } & \text { 10 SEER A/C, 4-ton } \\ \text { Cooling system } & 0.56 \mathrm{EF}\end{array}$

- Increased wall insulation (increment 1)

Wall cavity insulation is increased to a nominal R-19, based on 2-in. x 6-in. wall construction. This applies to all exterior walls as well as the wall between the house and garage.

- Vinyl frame window upgrade (increment 2)

Window frames are upgraded from metal frames (aluminum, no thermal break) to vinyl frames. The frame conductance in the DOE2 model changes from $3.037 \mathrm{Btu} / \mathrm{hr} \cdot \mathrm{ft}^{2} \cdot{ }^{\circ} \mathrm{F}$ to $0.50 \mathrm{Btu} / \mathrm{hr} \cdot \mathrm{ft}^{2} \cdot{ }^{\circ} \mathrm{F}$. These values include the inside film coefficient, but not the exterior film coefficient, and are based on two-dimensional heat loss.

- A/C upgrade to SEER 12 (increment 3)

The A/C SEER is increased from 10 to 12. For DOE2, the SEER is converted to a design energy-input-ratio (EIR) using the Title-24 recommended method, which separates out 
the assumed fan power and the compressor and condenser power. This increment brings the base case up to the Energy Star energy efficiency level.

\section{- A/C downsizing to 3 tons (increment 4)}

The $\mathrm{A} / \mathrm{C}$ capacity is decreased to 3 tons, from the base-case capacity of 4 tons. The total supply flow rate is reduced as well, remaining at 350 CFM per ton. Supply fan electric use changes from 0.55 watts per CFM to 0.60 watts per CFM.

This is the first added measure to the Energy Star configuration (increment 3) because it has a negative associated cost and small energy cost benefit. Installed cost of each measure is not included in Table $\mathrm{C}-2$, but should be provided if known.

\section{- Wall framing-factor reduction (increment 5)}

Exterior walls are changed to 24 in. o.c. from 16 in. o.c., increasing the effective R-value of the wall construction by approximately $1 \mathrm{Btu} / \mathrm{hr}-\mathrm{ft}^{2}-{ }^{\circ} \mathrm{F}$.

As with the previous increment, this measure is reported to have a negative first-cost and a small energy cost benefit.

\section{- High-performance glazing (increment 6)}

All windows are replaced with Sungate1000 high-performance windows. Sungate1000 has a low-e coating and a low solar gain factor. Center-of-glass U-value is $0.299 \mathrm{Btu} / \mathrm{hr}$ $\mathrm{ft}^{2}-{ }^{\circ} \mathrm{F}$, compared with 0.49 for the clear double glass it replaces. The glass shadingcoefficient is reduced to 0.37 , from 0.89 .

This measure has a significant energy impact and has a very quick payback period.

\section{- Unvented Roof (increment 7)}

The unvented roof design moves the attic insulation from the "ceiling" (actually, the attic floor) to the roof. The attic becomes unintentionally conditioned by duct leakage, conductive losses, and air transfer between the attic and house.

\section{Vented Attic (base) Vented Attic (E-Star) Unvented Attic}

\begin{tabular}{llll}
\hline Insulation & ceiling: R-30 & ceiling: R-0 & roof: R-21, walls: R-19 \\
Infiltration & $1.5 \mathrm{ACH}$ & $1.5 \mathrm{ACH}$ & $0.15 \mathrm{ACH}$ \\
Duct supply leakage & $7 \%$ of supply CFM & $3 \%$ of supply CFM & $3 \%$ of supply CFM \\
Leakage to outside & $80 \%(78 \mathrm{CFM})$ & $80 \%(25 \mathrm{CFM})$ & $25 \%(8 \mathrm{CFM})$ \\
Design duct delta-T & $1.5 \mathrm{~F}$ & $1.5 \mathrm{~F}$ & $1.5 \mathrm{~F}$
\end{tabular}

The tracer gas test shows the air-exchange rate associated with fan operation for the unvented roof to be very low, on the order of 8-10 CFM. The base-case test house with a vented roof also showed very low air exchange associated with fan operation.

Significantly higher air loss to the attic is assumed for the builder standard practice case. With a total supply flow rate of 1,400 CFM, builder standard practice is assumed to have about 98 CFM airflow loss to the attic (7\% of total). For the vented attics, it is assumed that $80 \%$ of the supply airflow to the attic is exhausted to the outside and thus made up from outside air. The remaining $20 \%$ is made up through return-air leaks from the attic. For the unvented attic, it is assumed that $75 \%$ of the air loss to the attic makes its way back to the conditioned space, either through return-air leaks or direct transfer from the attic to the house. The remaining $25 \%$ is made up from outside air. 


\section{- Heating System AFUE improvement (increment 8)}

The 80.0 AFUE furnace is replaced with a more efficient 92.6 AFUE furnace. The unvented attic measure requires using this more efficient, condensing furnace because the attic is now part of the conditioned space.

\section{- $\quad \mathbf{A} / \mathrm{C}$ downsizing to 2 tons (increment 9)}

The $\mathrm{A} / \mathrm{C}$ capacity is decreased to 2 tons, from the previous capacity of 3 tons. The total supply flow rate is reduced as well, remaining at 350 CFM per ton. Supply fan electric use changes from 0.60 watts per CFM to 0.65 watts per CFM. The smaller cooling capacity is only adequate after the cooling load has been reduced by the combination of better glazing and unvented attic.

\section{- DHW heater improvement (increment 10)}

The standard gas DHW heater with an Energy Factor (EF) of 0.56 is replaced with a heater with an EF of 0.62 .

\section{- A/C SEER 10 (increment 11)}

The A/C SEER is decreased from 12 to 10 . This cost trade-off measure was added last so that the previous measure would indicate the performance of the Building America home with a SEER of 12.

\section{Alternative Sequence}

The effectiveness of the unvented attic measure is highly dependent upon the magnitude of the duct losses and gains to the attic. These losses/gains are in turn dependent upon how often the HVAC system runs. In Tables C-1 and C-2, the unvented roof is added as a measure after all of the load reduction measures are in place and therefore reduce the effectiveness of the measure. In fact, the energy liability of increased effective shell area and decreased insulation levels of the unvented roof are shown to offset most of the gains from decreased duct losses and outdoor airexchange.

If benefits other than energy savings influence the ordering of the measures, the unvented attic measure might be installed before considering more cost effective measures, such as the highperformance glazing. Table C-3 shows the effect of re-ordering the sequence of measures. 
Table C-3. Alternative Sequence, Summary of Results, Space Heating \& Cooling only

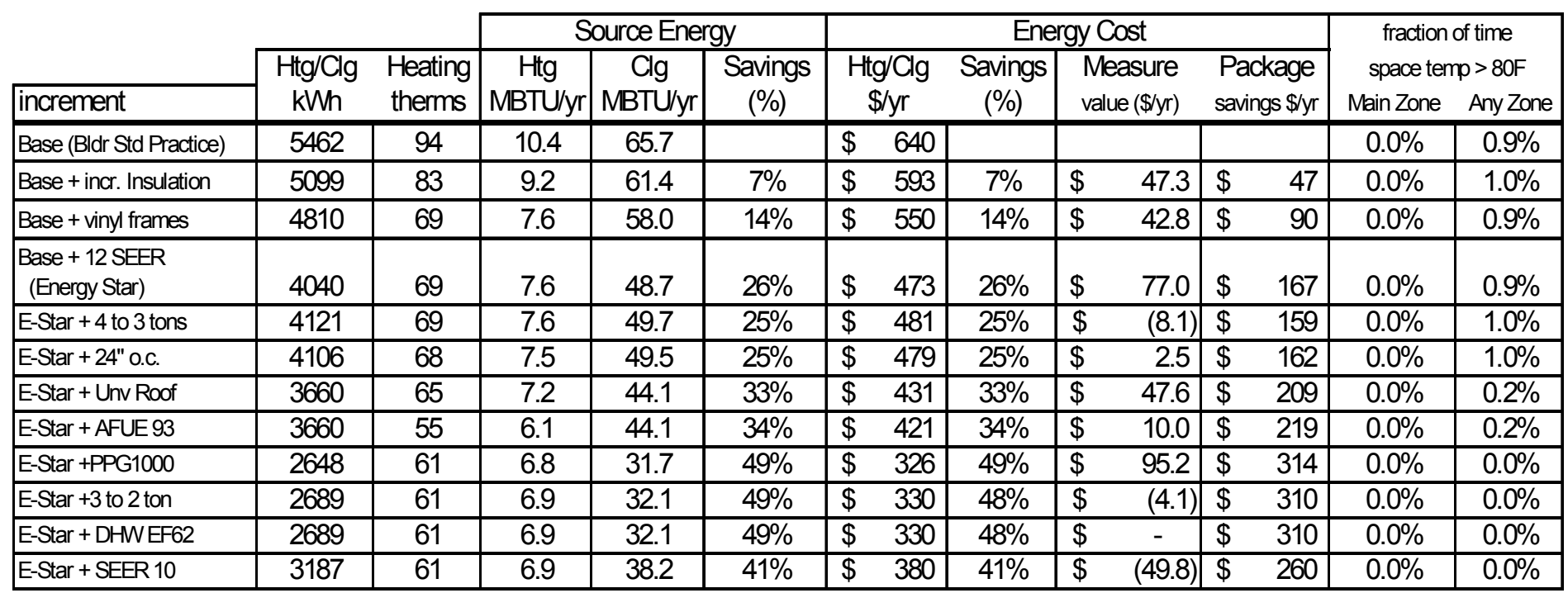

Interestingly, the unvented roof, used in this sequence, reduces the space heating energy use. In the previous sequence, the unvented roof measure increased the space heating energy use. Closer examination of the simulation results shows just how complex the interactions of the insulated shell, solar gain, duct leakage and outdoor air temperature are (see Figure C-3).

\section{Vented Attic Versus Unvented Attic}

The unvented vs. vented attic comparison attempts to capture a number of heat flows that are quite different between the two models. The primary heat flows are:

- Supply duct leakage, air flow loss to the attic

- Return duct leakage, air flow from the attic to the return air stream

- Air loss from the attic to the outside

- Air exchange between the attic and house

- Heat flow between the attic and house

- Induced outside make-up air

- Heat loss/gain from the ducts to the attic 


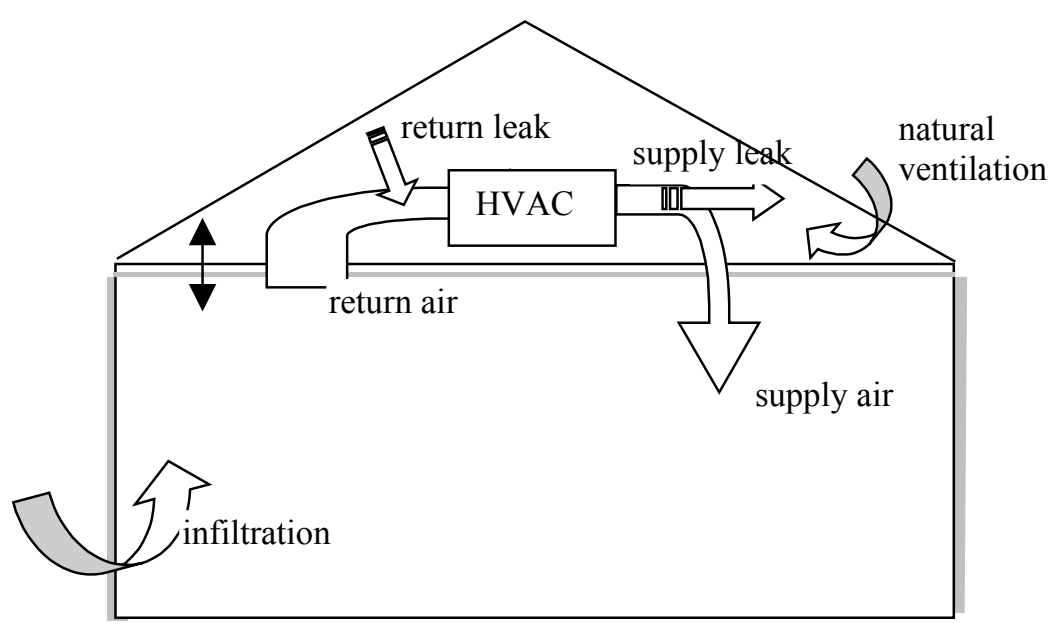

Figure C-3. Modeling of duct and attic interactions.

To best model these situations in DOE2.2, the attic is considered a conditioned space. This allows part of the flow rate to the attic to be lost to the outside (exhaust-cfm) and the remainder to be added to the return air. The air lost from the attic is made up with outside air added directly to the return-air stream. A series of sensitivity runs were made with the model to assure that building components were being modeled correctly and to gauge how important certain assumptions are. 


\section{Venture Homes in Atlanta, Georgia}

The following is an analysis of the Building America prototype house built in Atlanta by Venture Homes with design assistance from the IBACOS team. The analysis starts with the description of the Building America prototype house with energy features changed to builder standard practice, and incrementally adds features until the prototype house is simulated.

DOE2 and eQUEST were used to simulate the hourly energy use of the test homes. Figures C-4 and $\mathrm{C}-5$ show the building envelope as modeled in eQUEST. Figure C-6 shows the zoning of the first floor.

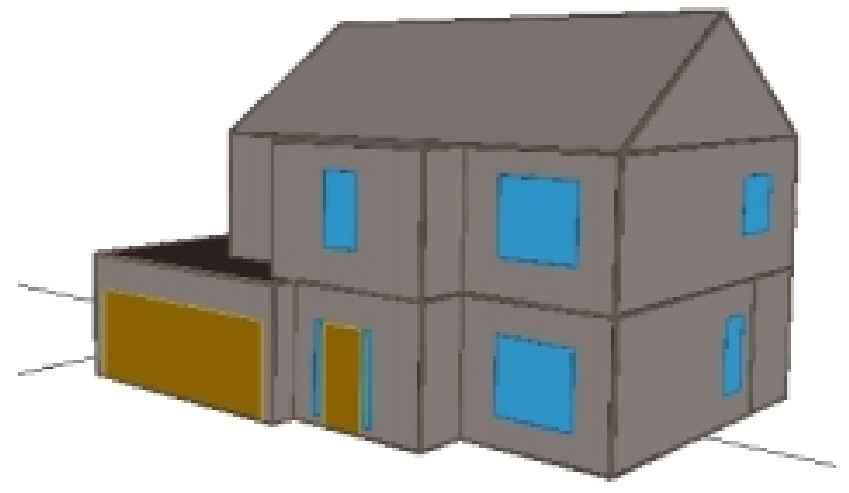

Figure C-4. Front of Prototype House (Image captured from eQUEST.)

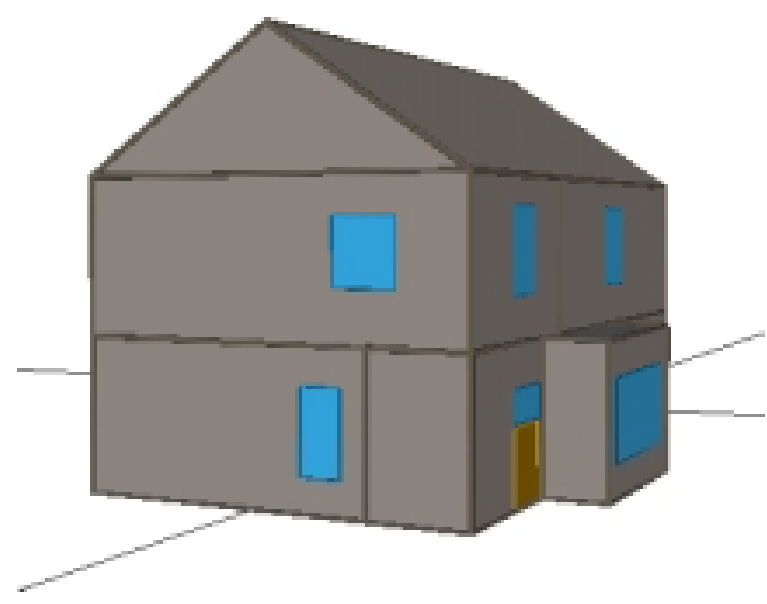

Figure C-5. Side and Back of Prototype House (Image captured from eQUEST.)

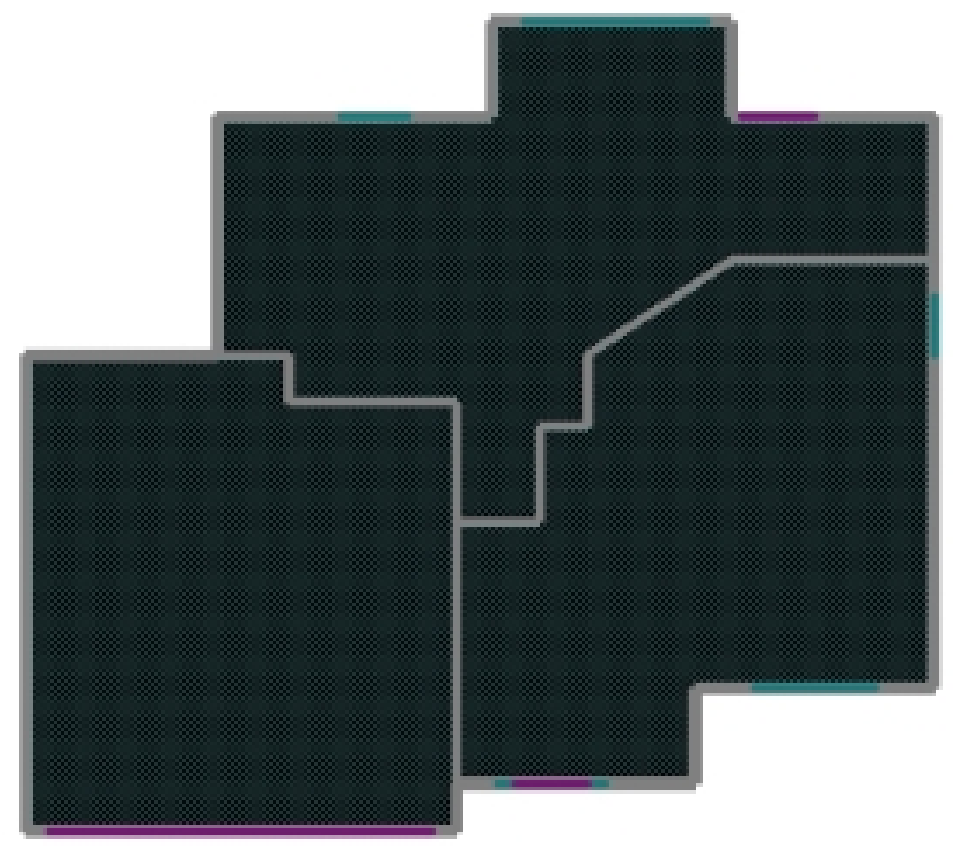

Figure C-6. First Floor zoning: Great Room, Kitchen/Dining and Garage. (Image captured from eQUEST.) 


\section{Common Features}

Test data were utilized to establish many of the inputs to the models, such as infiltration rates, $\mathrm{A} / \mathrm{C}$ performance and attic performance. The models were then modified to better capture "typical" occupant behavior and house operation over a full year.

Features common to all of the building simulations:

- Shading from nearby building and patio shading.

- Use of interior blinds \& draperies:

- Half of all windows are assumed to be covered at all times.

- When shades/draperies are used, the window R-value is increased by 1.0 .

- When shades/draperies are used, the shading coefficient is reduced by $40 \%$.

- Natural infiltration coefficients as measured during a tracer gas test. The residential infiltration model in DOE2 is used which determines the hourly infiltration rate based upon a constant, a wind-driven and a delta-temperature driven component. Infiltration induced by system fan operation and by intentional venting is included separately.

\section{Incremental Measures}

Table C-4 presents a summary of results for a series of simulations. This series starts with the builder standard practice building description and adds measures one at a time until the building complies with the Building America specifications. The order in which the measures are added to the building model was determined by a number of issues. Shell measures were added first, and then equipment measures were added to arrive at the prototype design. Two fenestration measures utilizing low-e glazings are investigated beyond the designed prototype. Standard lowe and low shading coefficient low-e glazing replaces the clear glass used in the prototype building.

The prototype building includes additional outside air ventilation provided by means of a duct the runs from the return air side of the air distribution to the outside. 
Table C-4. Summary of Results, South-facing front, with Duct OA Vents open

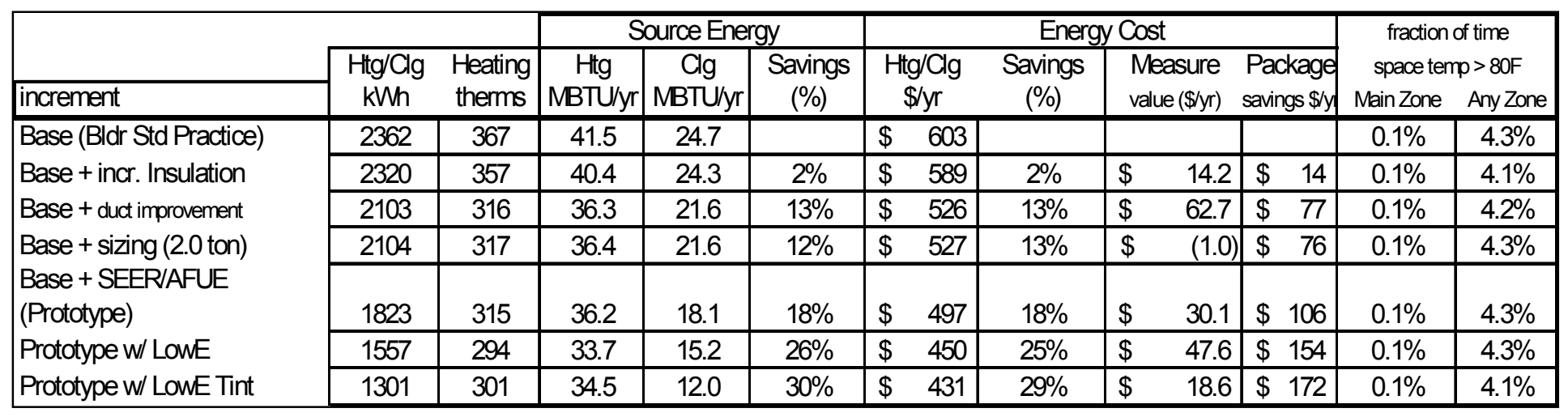

- Base Case (increment 0)

The base case, or starting point, for the analysis is based on a new house designed and built by Venture Homes in the Cypress Club development near Atlanta. This house was built to the Building America design. The energy features of this house are "degraded" to produce builder standard practice.

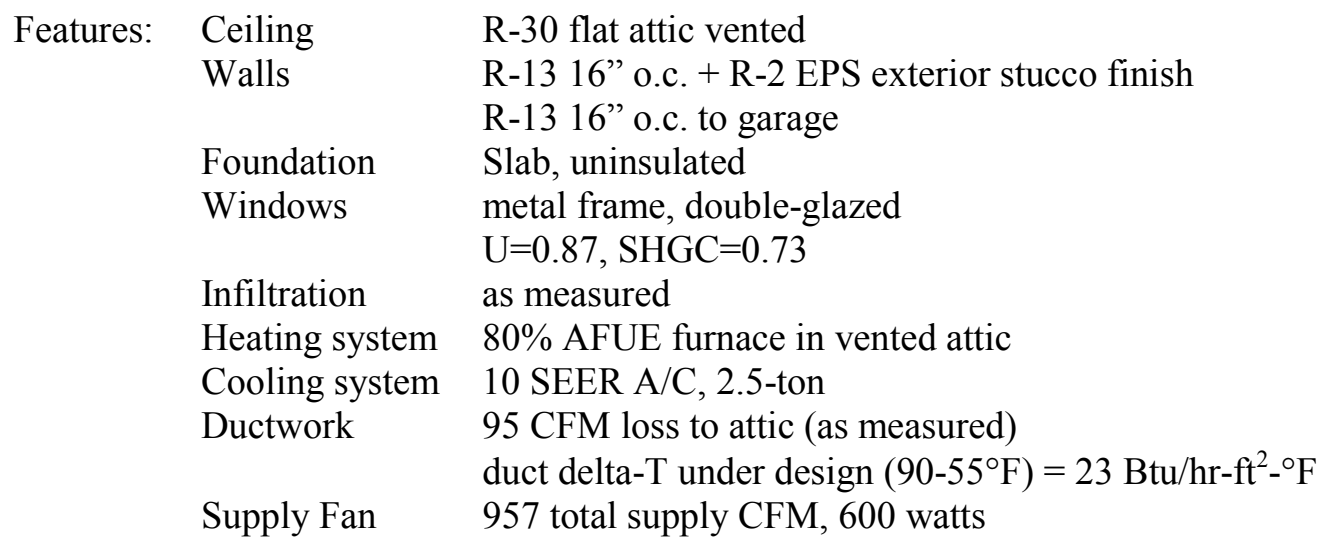

- Increased wall insulation (increment 1)

Wall framing factor is decreased and leads to an increase in the net cavity insulation of R1. Attic ceiling insulation increased to nominal R-38.

- Duct Re-design (increment 2)

The majority of ductwork is brought into the conditioned space, lowering the supply air losses as well as the conductive heat loss of the ducts to unconditioned spaces. Unintentional air losses to the attic are lowered from 95 CFM to 30 CFM. Intentional outside air introduced into the return air side of the ductwork increases the air exchange by a measured 50 CFM while the system is operating.

\section{- A/C downsizing to 2.0 tons (increment 3)}

The A/C capacity is decreased to 2 tons, from the base-case capacity of 2.5 tons. The total supply flow rate is reduced to $837 \mathrm{CFM}$, as measured in the prototype building. Supply fan electric use changes from 0.55 watts per CFM to 0.60 watts per CFM. 
- HVAC Equipment efficiency improvement (increment 4)

The air conditioning equipment is modeled as a SEER 12, versus the basecase of SEER 10. The heating system is improved to an AFUE of 82, versus the base case of 80 .

- High-performance glazing (increment 5)

All windows are replaced with standard low-E windows. Center-of-glass U-value is 0.32 $\mathrm{Btu} / \mathrm{hr}-\mathrm{ft}^{2}-{ }^{\circ} \mathrm{F}$, compared with 0.49 for the clear double glass it replaces. The glass shading-coefficient is reduced from 0.89 to 0.69 .

- High-performance glazing (increment 6)

All windows are replaced with Sungate1000 high-performance windows. Sungate1000 has a low-e coating and a low solar heat-gain coefficient. Center-of-glass U-value is $0.299 \mathrm{Btu} / \mathrm{hr} \cdot \mathrm{ft}^{2} \cdot{ }^{\circ} \mathrm{F}$, compared with 0.49 for the clear double glass it replaces. The glass shading-coefficient is reduced from 0.89 to 0.37 .

\section{Incremental Savings without Added Ventilation}

The addition of the outside air duct in the prototype building was done for the sake of air-quality and not as an energy saving measure. In fact, by inducing an additional $50 \mathrm{CFM}$ of outside air whenever the supply fan operates, there is a significant negative energy impact on both the heating and cooling systems. Table C-5 shows the energy analysis conducted without the impact of the outside air duct. Overall energy cost savings for the prototype case increases from $18 \%$ to $25 \%$ if the increased ventilation is not accounted for. Comparing Table C-5 to Table $\mathrm{C}-4$, the additional ventilation is seen to cost $\$ 39$ per year, or about $8 \%$ of the total heating and cooling cost.

Table C-5. Summary of Results, South-facing front, with Duct OA Vents Closed

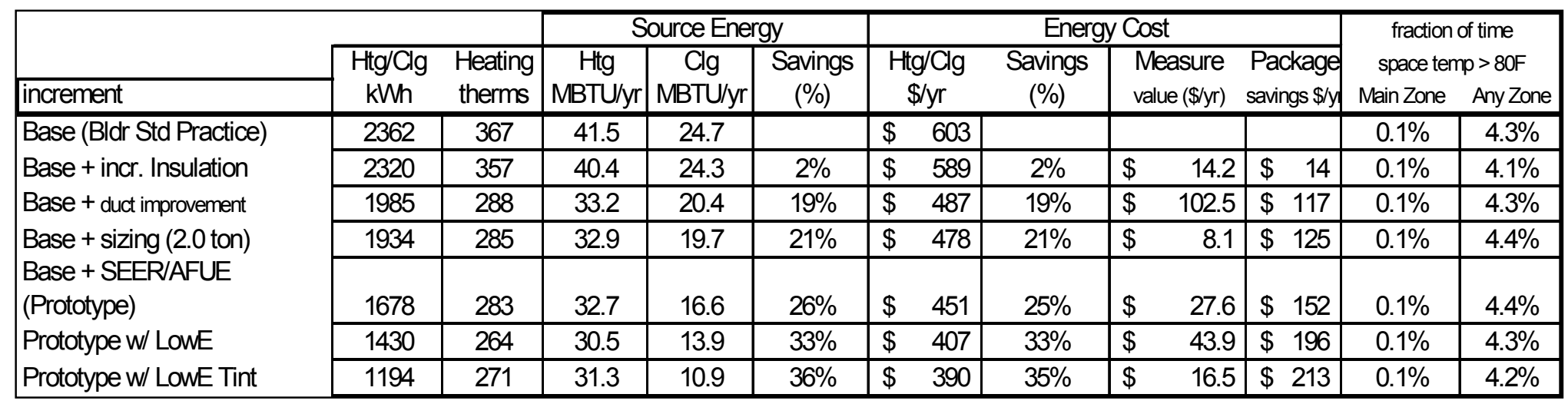




\section{Alternative Orientation}

The prototype house has the majority of windows on the front and back, as can be seen in Figures C-4 and C-5. Rotating the house 90 degrees so that the majority of glass faces east and west instead of north and south significantly increased the cooling load due to direct solar gain. Table C-6 shows the energy analysis when the front of the house faces east instead of south.

Table C-6. Summary of Results, East-facing Front, with Duct OA Vents Closed.

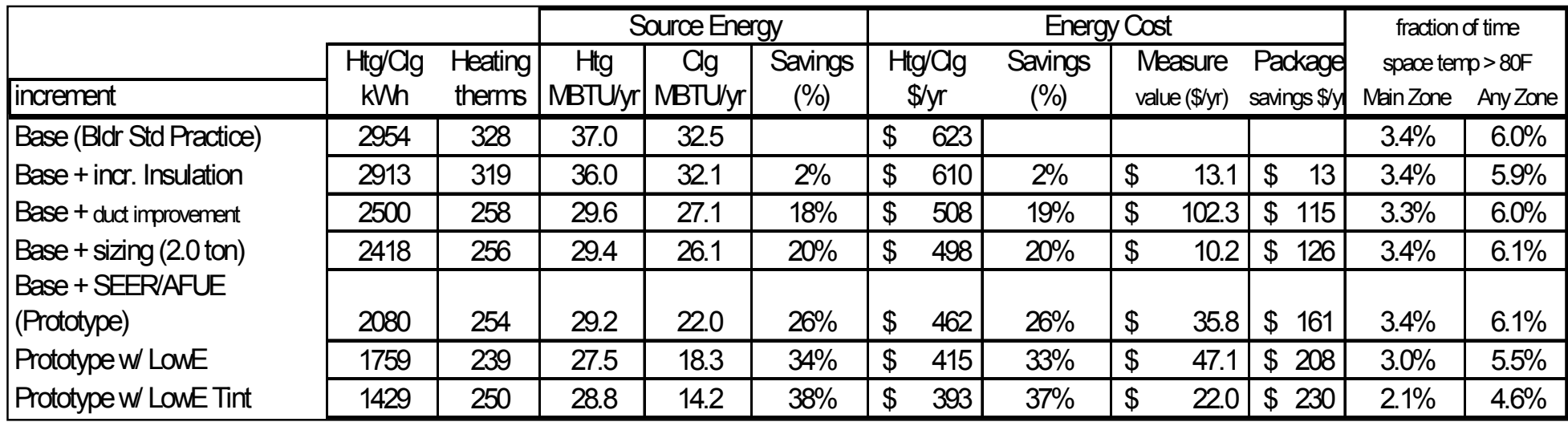

\section{Specifying Infiltration Base on Measured Data}

For both the base case and prototype sites, fan on-time, hourly air-exchange rates, indoor and outdoor temperatures as well as local wind speed values were measured on an hourly basis for approximately 10 days in August 1999. These data were used to develop a simple least-squares regression to predict the hourly air-exchange rate based on the fan run-time, indoor-outdoor temperature difference and wind speed. Figures C-7 and C-8 show the correlation between measured air-change rate and the air-change rate predicted by the regression model for both test houses. The curves are defined as follows:

- "Measured" is the air exchange as measured with the tracer-gas test, including outdoor air induced by fan operation and natural infiltration.

- "Predicted" is the result of a least-squares regression for the total air exchange based on wind speed, fan operation and indoor-outdoor temperature difference.

- $\quad$ "NACH (pred)" is the natural air changes excluding duct leakage effects as predicted by a least squares regression to the measured data.

- $\quad$ "Pred (adj)" is based on the final coefficients used in DOE2. These are basically the same coefficients produced by the regression analysis, but with slight adjustments (inspired by visual inspection of the graphs) and rounded off.

Figure C-9 provides a summary of average monthly air-change rate for the prototype and base case houses. 


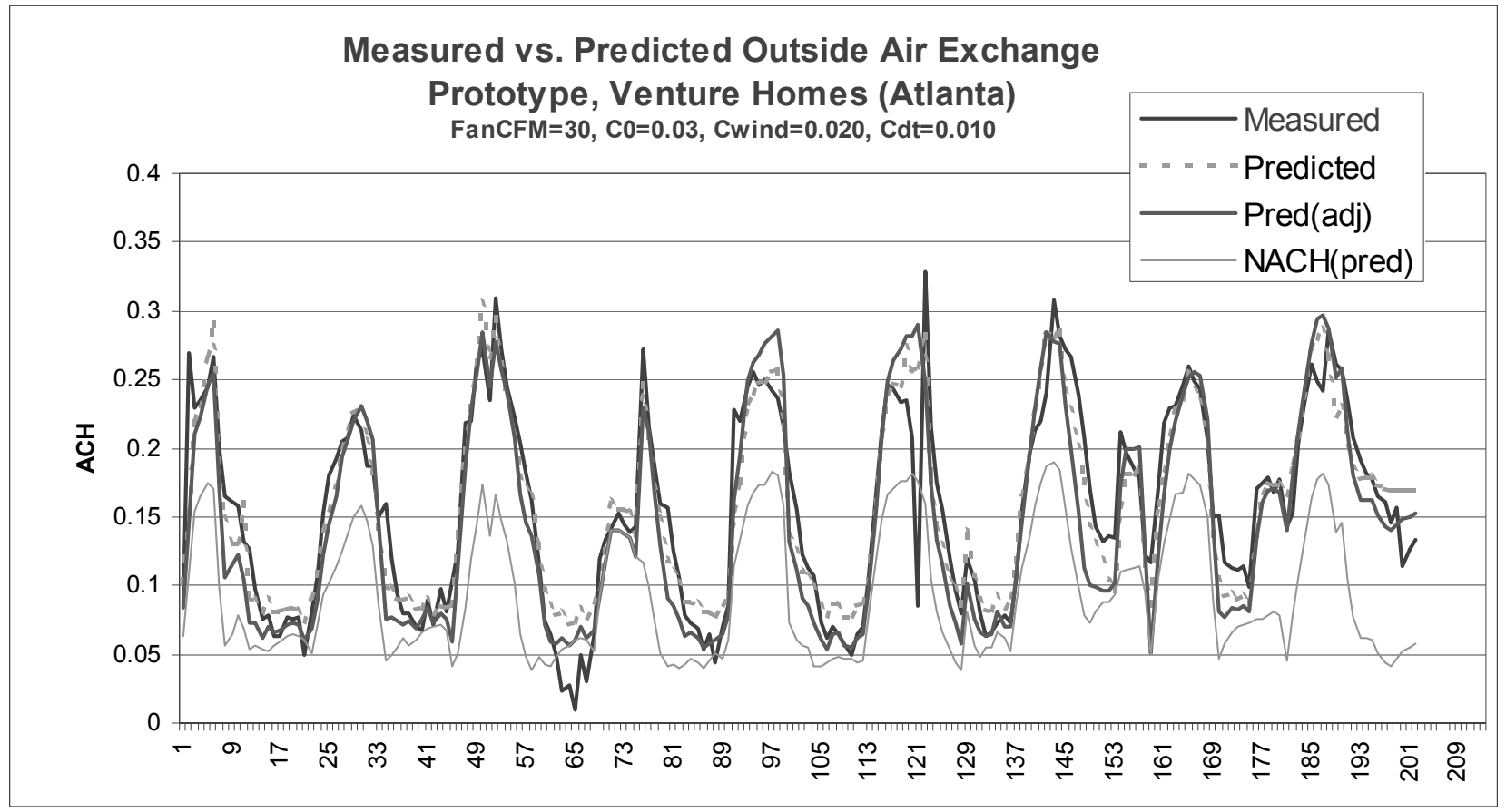

Figure C-7. Predicting air-exchange in the Prototype house.

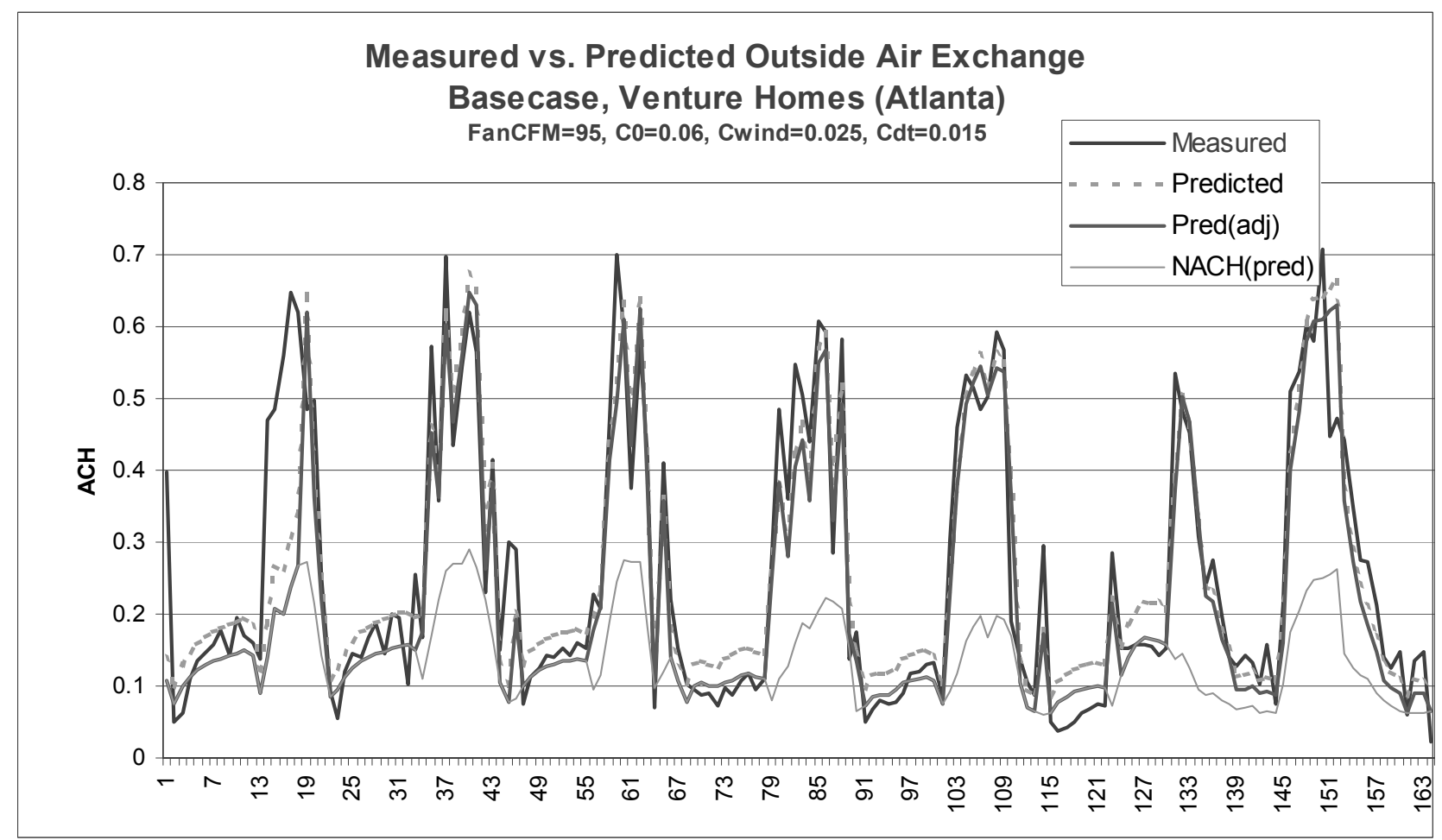

Figure C-8. Predicting air-exchange in the base-case house. 


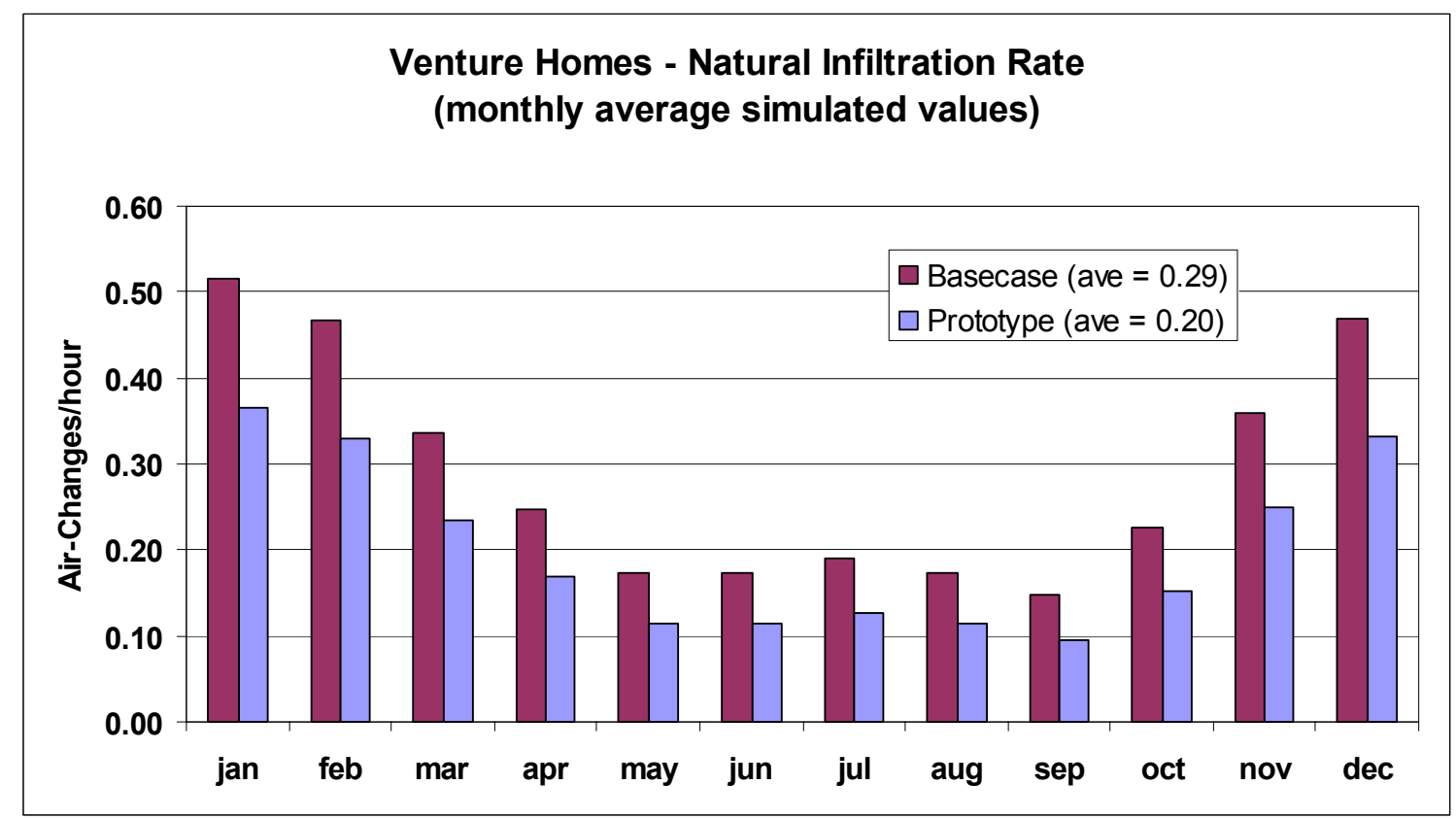

Figure C-9. Monthly natural infiltration rate as modeled in DOE-2.2, based on regression analysis.

\section{Mitchell Homes in Pensacola, Florida}

The following is an analysis of the Building America prototype house built in Pensacola by Mitchell Homes with design assistance from the CARB team. The analysis starts with the description of the Building America prototype house with energy features consistent with builder standard practice, and incrementally adds features until the prototype house is simulated.

DOE2 and eQUEST were used to simulate the hourly energy use of the test homes. Figures C-10 and $\mathrm{C}-11$ show the building envelope as modeled in eQUEST. Figure $\mathrm{C}-12$ shows the zoning of the first floor. 


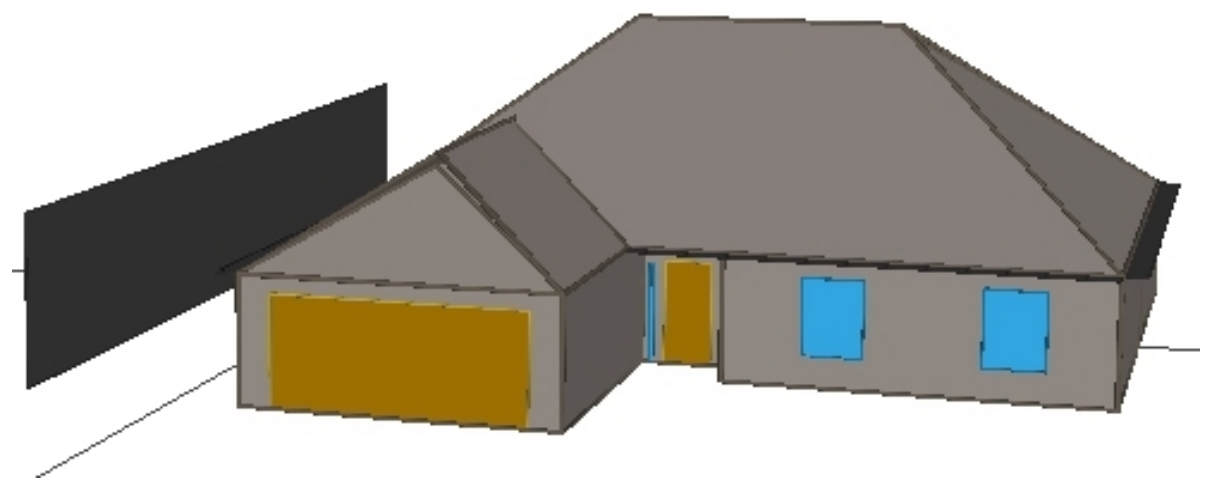

Figure C-10. Front of Prototype House. (Image captured from eQUEST.)

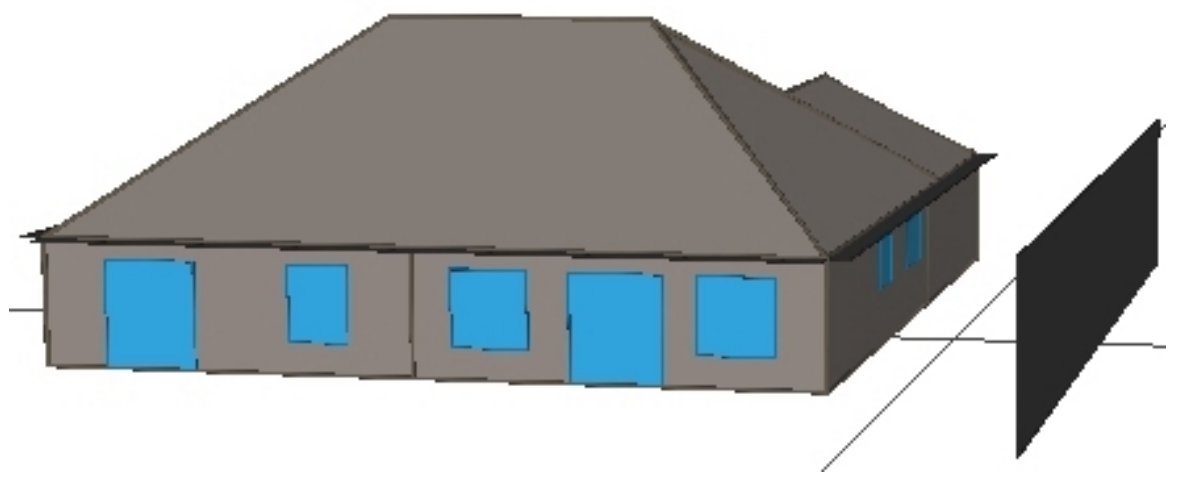

Figure C-11. Side and Back of Prototype House. (Image captured from eQUEST.) 


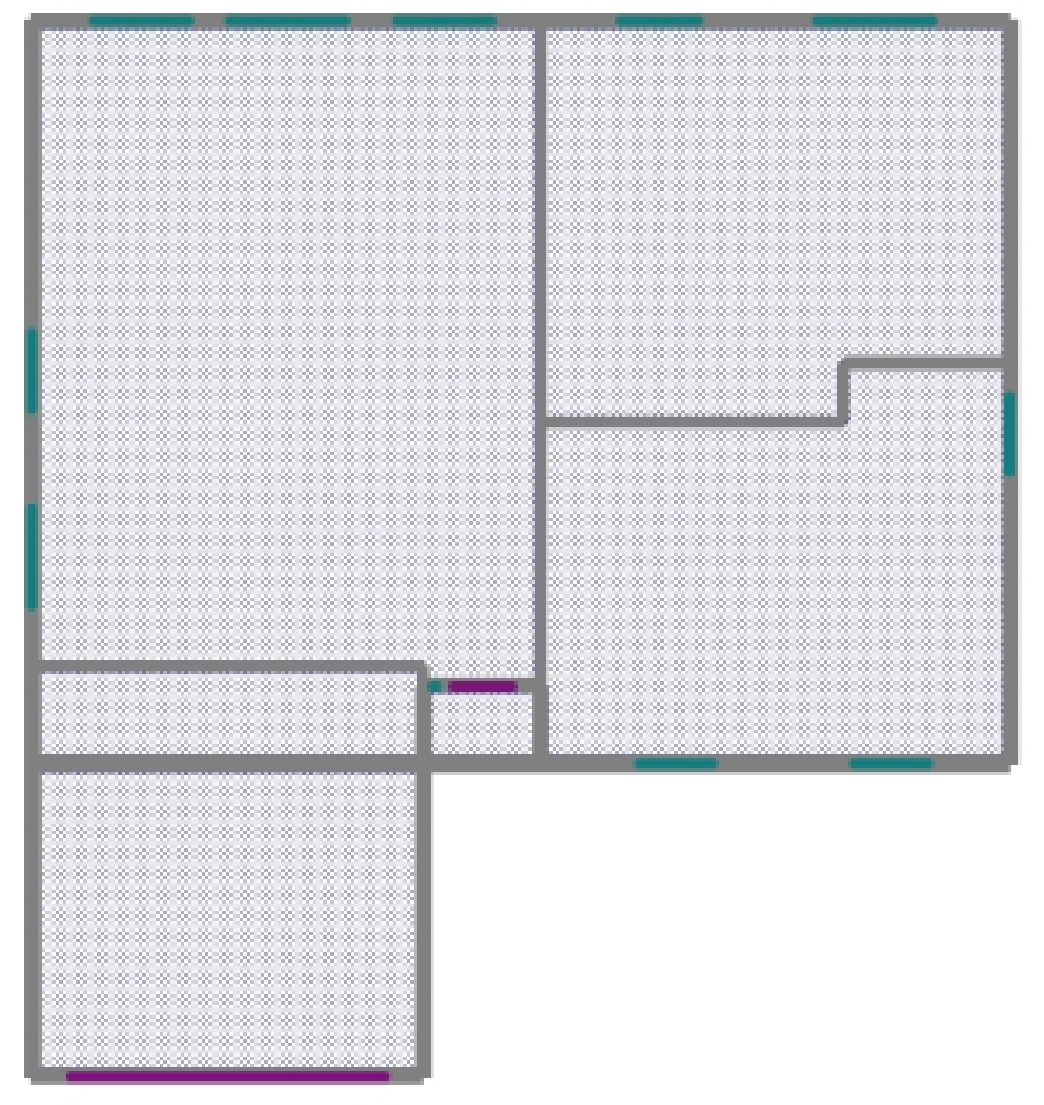

Figure C-12. First Floor zoning: Great Room, Kitchen/Dining, Bedrooms and Garage. (Image captured from eQUEST.)

\section{Common Features}

Test data were utilized to establish many of the inputs to the models, such as infiltration rates, $\mathrm{A} / \mathrm{C}$ performance and attic performance. The models were then modified to better capture "typical" occupant behavior and house operation over a full year.

Features common to all of the building simulations:

- Shading from nearby building and patio shading.

- Use of interior blinds \& draperies:

- Half of all windows are assumed to be covered at all times.

$\circ$ When shades/draperies are used, the window R-value is increased by 1.0 .

- When shades/draperies are used, the shading coefficient is reduced by $40 \%$.

- Natural infiltration coefficients as measured during a tracer gas test. The residential infiltration model in DOE2 is used which determines the hourly infiltration rate based upon a constant, a wind-driven and a delta-temperature driven component. Infiltration induced by system fan operation and by intentional venting is included separately. 


\section{Incremental Measures}

Table C-7 presents a summary of results for a series of simulations. This series starts with the builder standard practice building description and adds measures one at a time until the building matches the prototype specifications. The order in which the measures are added to the building model was determined by a number of issues. Shell measures were added first, and then equipment measures were added to arrive at the prototype design. Even though clear glass windows were mistakenly installed in the prototype house, low-e glazing was included in the analysis as an energy saving design measure that was intended for use in the prototype house. The prototype building also includes additional outside air ventilation provided by means of a duct that runs from the return air side of the air handler to the outside of the house.

Table C-7. Summary of Results, West-facing front (actual orientation)

\begin{tabular}{|c|c|c|c|c|c|c|c|c|c|c|c|c|c|}
\hline \multirow[b]{3}{*}{ increment } & \multirow{3}{*}{$\begin{array}{l}\mathrm{Htg} / \mathrm{Clg} \\
\mathrm{kWh}\end{array}$} & \multirow{3}{*}{$\begin{array}{l}\text { Heating } \\
\text { therms }\end{array}$} & \multicolumn{3}{|c|}{ Source Energy } & \multicolumn{6}{|c|}{ Energy Cost } & \multirow{2}{*}{\multicolumn{2}{|c|}{$\begin{array}{l}\text { fraction of time } \\
\text { space temp }>80 F\end{array}$}} \\
\hline & & & \multirow{2}{*}{$\begin{array}{c}\mathrm{Htg} \\
\mathrm{MBTU} / \mathrm{yr}\end{array}$} & \multirow{2}{*}{$\begin{array}{c}\mathrm{Cg} \\
\text { MBTU/yr }\end{array}$} & \multirow{2}{*}{$\begin{array}{l}\text { Savings } \\
\text { (\%) }\end{array}$} & \multirow{2}{*}{\multicolumn{2}{|c|}{$\begin{array}{c}\mathrm{Htg} / \mathrm{Clg} \\
\$ / \mathrm{yr}\end{array}$}} & \multirow{2}{*}{$\begin{array}{l}\text { Savings } \\
\text { (\%) }\end{array}$} & \multirow{2}{*}{\multicolumn{2}{|c|}{$\begin{array}{l}\text { Measure } \\
\text { value }(\$ / y r)\end{array}$}} & \multirow{2}{*}{$\begin{array}{l}\text { Package } \\
\text { savings } \$ / y\end{array}$} & & \\
\hline & & & & & & & & & & & & Main Zone & Any Zone \\
\hline Base (Bldr Std Practice) & 3716 & 182 & 25.0 & 38.8 & & $\$$ & 442 & & & & & $0.3 \%$ & $0.8 \%$ \\
\hline Base + imp. windows & 3113 & 158 & 21.5 & 32.6 & $15 \%$ & $\$$ & 376 & $15 \%$ & $\$$ & 65.6 & 66 & $0.0 \%$ & $0.6 \%$ \\
\hline Base ++ interior ducts & 2837 & 144 & 19.6 & 29.6 & $23 \%$ & $\$$ & 343 & $22 \%$ & $\$$ & 33.3 & 99 & $0.0 \%$ & $0.6 \%$ \\
\hline Base ++ SEER12 & 2371 & 144 & 19.6 & 24.0 & $32 \%$ & $\$$ & 313 & $29 \%$ & $\$$ & 30.3 & $\$ 129$ & $0.0 \%$ & $0.6 \%$ \\
\hline Base ++ HP & 3772 & 0 & 20.3 & 25.7 & $28 \%$ & $\$$ & 245 & $44 \%$ & $\$$ & 67.3 & \$ 197 & $0.0 \%$ & $0.0 \%$ \\
\hline
\end{tabular}

\section{- Base Case (increment 0)}

The base case, or starting point, for the analysis is based on a new house designed and built by Mitchell Homes in Pensacola using their standard design and construction practices. The energy features of this house are "downgraded" from the prototype specifications to builder standard practice.

$\begin{array}{lll}\text { Features: } & \text { Ceiling } & \text { R-38 vented attic } \\ \text { Walls } & \text { R-13 16" o.c. + R-2 EPS exterior stucco finish } \\ & \text { R-13 16" o.c. to garage } \\ \text { Foundation } & \text { Slab, uninsulated } \\ \text { Windows } & \text { Metal frame, double-glazed } \\ & \text { U=0.87, SHGC=0.73 } \\ \text { Infiltration } & \text { As measured } \\ \text { Heating system } & 78 \% \text { AFUE furnace in vented attic } \\ \text { Cooling system } & \text { 10 SEER A/C, 2.5-ton } \\ \text { Ductwork } & \text { 88 CFM loss to attic (as measured) } \\ & \text { Average duct delta-T under design }\left(90-55^{\circ} \mathrm{F}\right)=2.5^{\circ} \mathrm{F} \\ \text { Supply Fan } & 875 \text { total supply CFM, } 480 \text { watts }\end{array}$


- High-performance glazing (increment 1)

All windows are replaced with Anderson Low-E windows. Center-of-glass U-value is

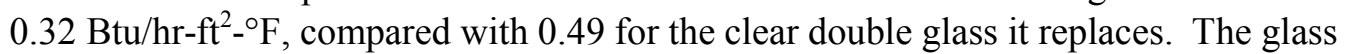
shading-coefficient is reduced to 0.69 , from 0.89 .

- Duct Re-design (increment 2)

The majority of ductwork is brought into the conditioned space, lowering the supply air losses as well as the conductive heat loss of the ducts to unconditioned spaces.

Unintentional air losses to the attic are lowered from 88 CFM to 44 CFM. Intentional outside air introduced into the return air side of the ductwork increases the air exchange by a measured $50 \mathrm{CFM}$ while the system is operating.

- Cooling Equipment efficiency improvement (increment 3)

The air conditioning equipment is modeled as a SEER 12, versus the standard practice of SEER 10.

\section{- $\quad$ Alternative Heating Equipment - Heat Pump (increment 4)}

The gas furnace is replaced with a heat pump matched to the cooling equipment specifications (12 SEER, 2.5 ton cooling capacity). The backup heat type is electric resistance.

\section{Incremental Savings for Other Orientations}

The majority of windows in the house are on the back wall. For the test house, this means the majority of the windows face east. Because the annual heating and cooling loads vary significantly with the orientation of the building, energy and cost savings of the various measures are also a function of the house orientation. Tables C-8 through C-10 show the same EEM analysis for the building facing the other three cardinal directions. Figure C-13 shows a quick comparison of the measure savings by house orientation.

Table C-8. Summary of Results, South-facing front

\begin{tabular}{|c|c|c|c|c|c|c|c|c|c|c|c|c|c|}
\hline \multirow[b]{3}{*}{ increment } & & & \multicolumn{3}{|c|}{ SourceEnergy } & \multicolumn{6}{|c|}{ Energy Cost } & \multirow{2}{*}{\multicolumn{2}{|c|}{$\begin{array}{l}\text { fraction of time } \\
\text { spece temp }>80 F\end{array}$}} \\
\hline & \multirow{2}{*}{$\begin{array}{c}\mathrm{Hg} / \mathrm{Cg} \\
\mathrm{kWh}\end{array}$} & \multirow{2}{*}{$\begin{array}{l}\text { Heating } \\
\text { therms }\end{array}$} & \multirow{2}{*}{$\begin{array}{c}\mathrm{Htg} \\
\text { MBTU/yr }\end{array}$} & \multirow{2}{*}{$\begin{array}{c}\text { Cgg } \\
\text { MBTU/yr }\end{array}$} & \multirow{2}{*}{$\begin{array}{l}\text { Savings } \\
(\%)\end{array}$} & \multirow{2}{*}{\multicolumn{2}{|c|}{$\begin{array}{c}\mathrm{Hig} / \mathrm{Cg} \\
\$ / \mathrm{yr}\end{array}$}} & \multirow{2}{*}{$\begin{array}{l}\text { Savings } \\
(\%)\end{array}$} & \multirow{2}{*}{\multicolumn{2}{|c|}{$\begin{array}{l}\text { Measure } \\
\text { value }(\$ / y r)\end{array}$}} & \multirow{2}{*}{$\begin{array}{l}\text { Package } \\
\text { savings \$y }\end{array}$} & & \\
\hline & & & & & & & & & & & & MainZone & AnyZone \\
\hline Base (Bldr Std Practice) & 3138 & 167 & 224 & 328 & & $\$$ & 388 & & & & & $0.0 \%$ & $0.6 \%$ \\
\hline Base + imp. windows & 2632 & 146 & 19.4 & 27.6 & $15 \%$ & $\$$ & 332 & $14 \%$ & $\$$ & 56.0 & $\$ 56$ & $0.0 \%$ & $0.6 \%$ \\
\hline Base ++ interior ducts & 2397 & 134 & 17.8 & 25.1 & $22 \%$ & $\$$ & 303 & $22 \%$ & $\$$ & 28.5 & $\$ 85$ & $0.0 \%$ & $0.6 \%$ \\
\hline Base++SEIR12 & 2004 & 134 & 17.8 & 20.3 & $31 \%$ & $\$$ & 278 & $28 \%$ & $\$$ & 25.5 & $\$ 110$ & $0.0 \%$ & $0.6 \%$ \\
\hline Base ++HP & 3299 & 0 & 18.3 & 21.9 & $27 \%$ & $\$$ & 214 & $45 \%$ & $\$$ & 63.2 & $\$ 173$ & $0.0 \%$ & $0.0 \%$ \\
\hline
\end{tabular}


Table C-9. Summary of Results, East-facing front

\begin{tabular}{|c|c|c|c|c|c|c|c|c|c|c|c|c|c|}
\hline \multirow[b]{3}{*}{ increment } & & & \multicolumn{3}{|c|}{ Source Energy } & \multicolumn{6}{|c|}{ Energy Cost } & \multirow{2}{*}{\multicolumn{2}{|c|}{$\begin{array}{l}\text { fraction of time } \\
\text { space temp }>80 F\end{array}$}} \\
\hline & \multirow{2}{*}{$\begin{array}{c}\mathrm{Htg} / \mathrm{Cg} \\
\mathrm{kWh}\end{array}$} & \multirow{2}{*}{$\begin{array}{l}\text { Heating } \\
\text { therms }\end{array}$} & \multirow{2}{*}{$\begin{array}{c}\mathrm{Htg} \\
\text { MBTU/yr }\end{array}$} & \multirow{2}{*}{$\begin{array}{c}\mathrm{Clg} \\
\text { MBTU/yr }\end{array}$} & \multirow{2}{*}{$\begin{array}{l}\text { Savings } \\
(\%)\end{array}$} & \multirow{2}{*}{\multicolumn{2}{|c|}{$\begin{array}{c}\mathrm{H} / \mathrm{dg} / \mathrm{Cg} \\
\$ / \mathrm{yr}\end{array}$}} & \multirow{2}{*}{$\begin{array}{c}\text { Savings } \\
(\%)\end{array}$} & \multirow{2}{*}{\multicolumn{2}{|c|}{$\begin{array}{l}\text { Measure } \\
\text { value }(\$ / y r)\end{array}$}} & \multirow{2}{*}{$\begin{array}{l}\text { Package } \\
\text { savings } \$ / y\end{array}$} & & \\
\hline & & & & & & & & & & & & Main Zone & Any Zone \\
\hline Base (Bldr Std Practice) & 3787 & 191 & 26.0 & 39.6 & & $\$$ & 456 & & & & & $0.0 \%$ & $0.6 \%$ \\
\hline Base + imp. windows & 3161 & 164 & 22.2 & 33.1 & $16 \%$ & $\$$ & 386 & $15 \%$ & $\$$ & 70.4 & 70 & $0.0 \%$ & $0.6 \%$ \\
\hline Base ++ interior ducts & 2887 & 150 & 20.3 & 30.2 & $23 \%$ & $\$$ & 353 & $23 \%$ & $\$$ & 33.3 & $\$ 104$ & $0.0 \%$ & $0.6 \%$ \\
\hline Base ++ SEER12 & 2412 & 150 & 20.3 & 24.4 & $32 \%$ & $\$$ & 322 & $29 \%$ & $\$$ & 30.9 & $\$ 135$ & $0.0 \%$ & $0.6 \%$ \\
\hline Base +HP & 3816 & 0 & 20.4 & 26.1 & $29 \%$ & $\$$ & 248 & $46 \%$ & $\$$ & 73.7 & $\$ 208$ & $0.0 \%$ & $0.0 \%$ \\
\hline
\end{tabular}

Table C-10. Summary of Results, North-facing front

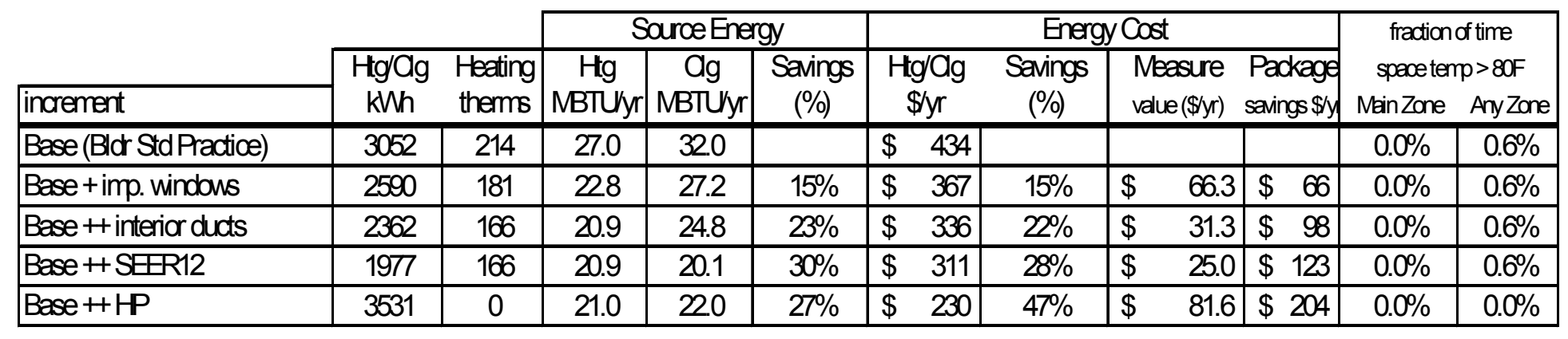

\section{EEM Savings by Orientation of Building}

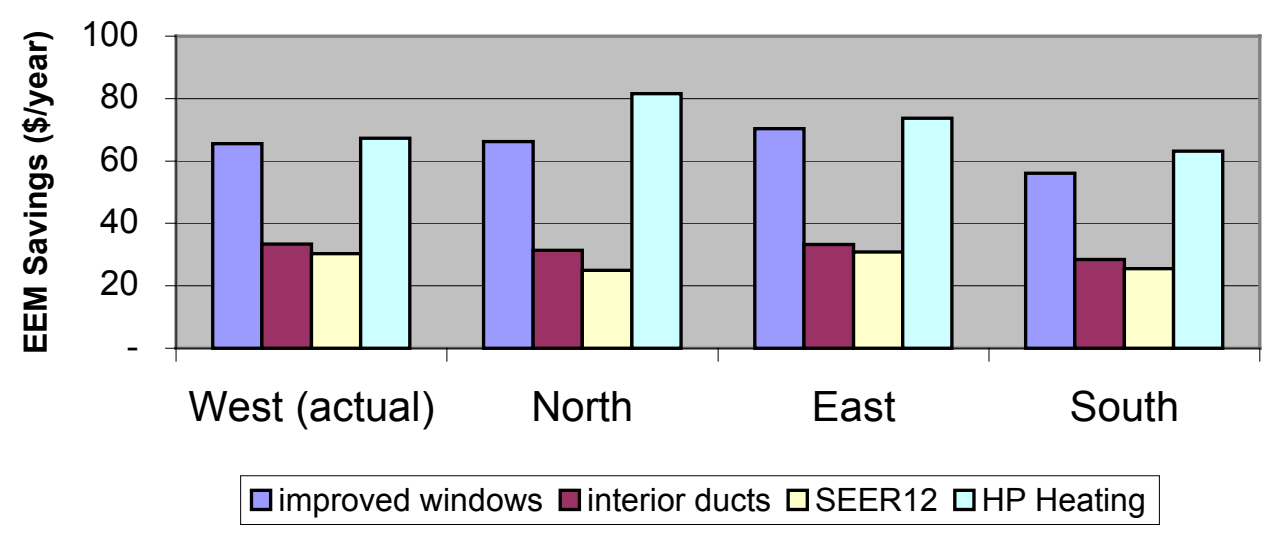

Figure C-13. Comparison of EEM Savings by House Orientation. 


\section{Appendix D. Sample Simulation Files}

Whereas each residential design for the Building America project is unique, the process of creating the models within the context of DOE-2.2 is always fairly similar. Houses may vary from single story with slab-on-grade foundation to two-story with a basement, but that range is actually very small with respect to the range of building types that can be modeled in DOE- 2 . It is this fact that allows the analyst to create new models relatively quickly and efficiently. The beginning point for a new model is almost always a previous project that was similar in number of stories or foundation type.

The sample files supplied with this report serve to both illustrate examples of modeling techniques and act as a template for new projects. Much of the structure of the DOE-2 input file is arbitrary - the title section can come at the end of the file, the reports sections can come at the beginning, command and keyword abbreviations can be used or they can be spelled out completely. However, using a consistent format for the model description, such as is provided below, will save much time and effort by all parties involved.

\section{Input File}

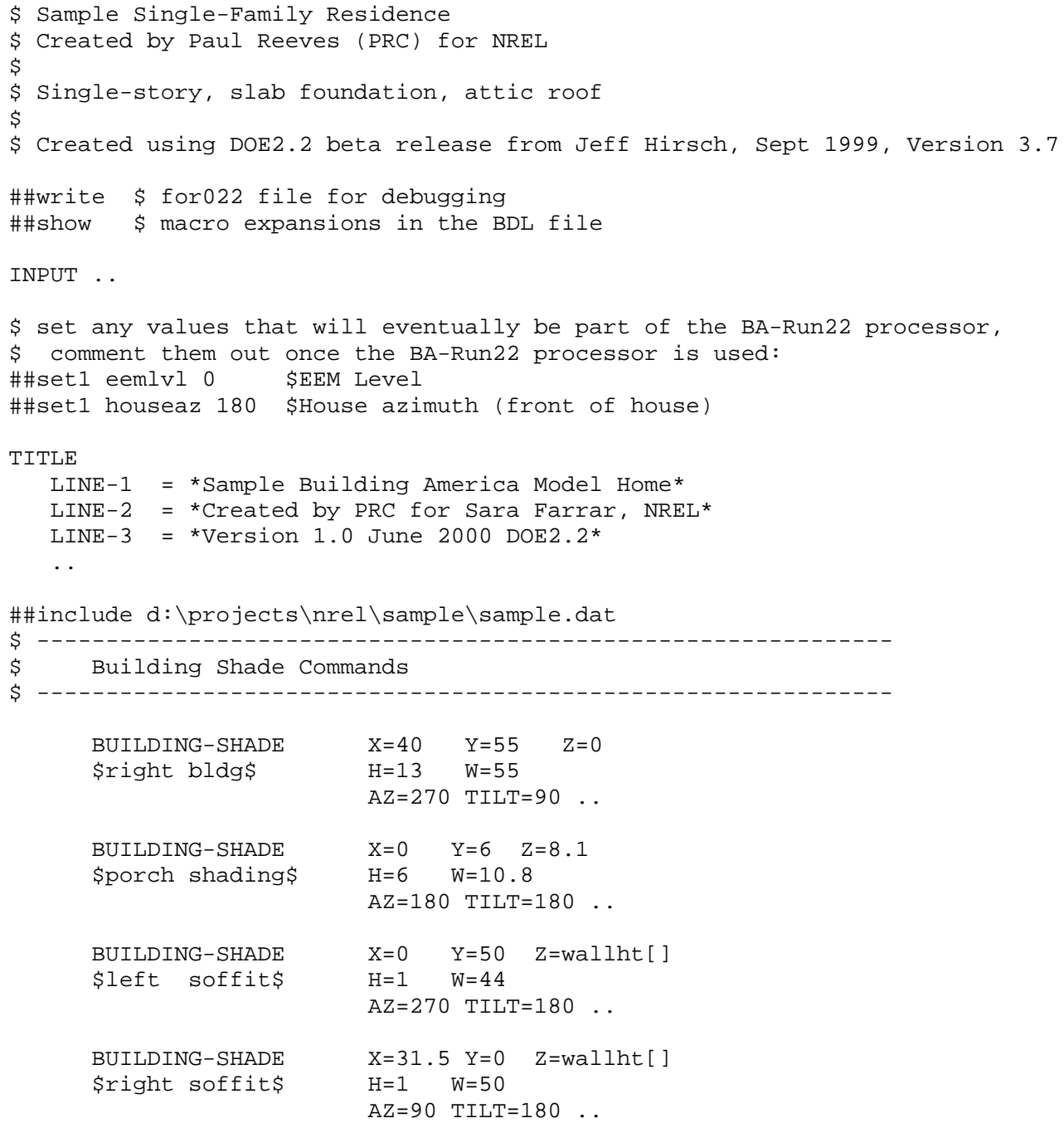




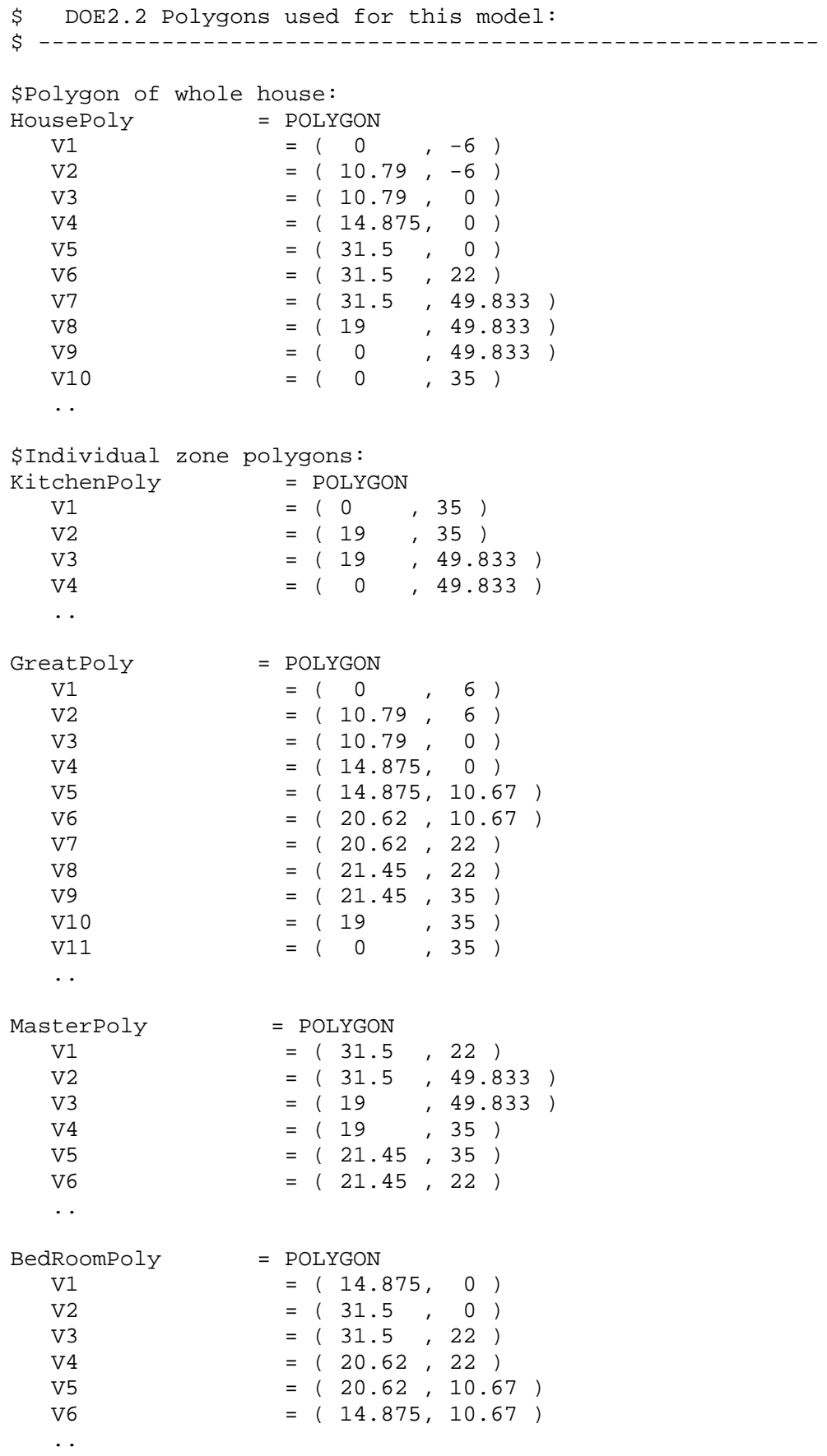




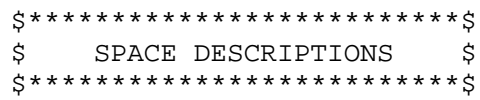

HOUSE-SC $=$ SPACE-CONDITIONS

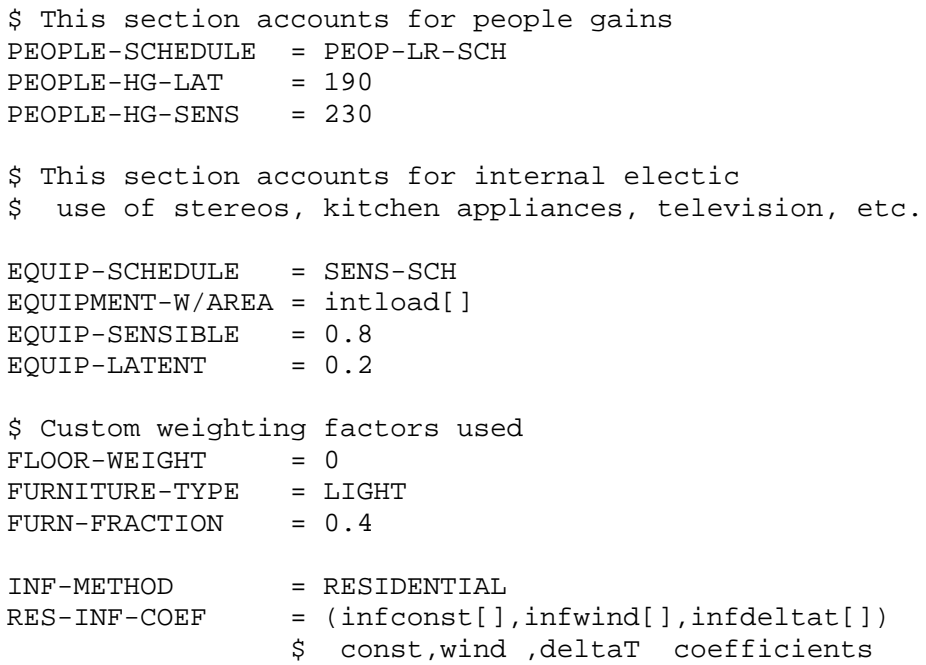




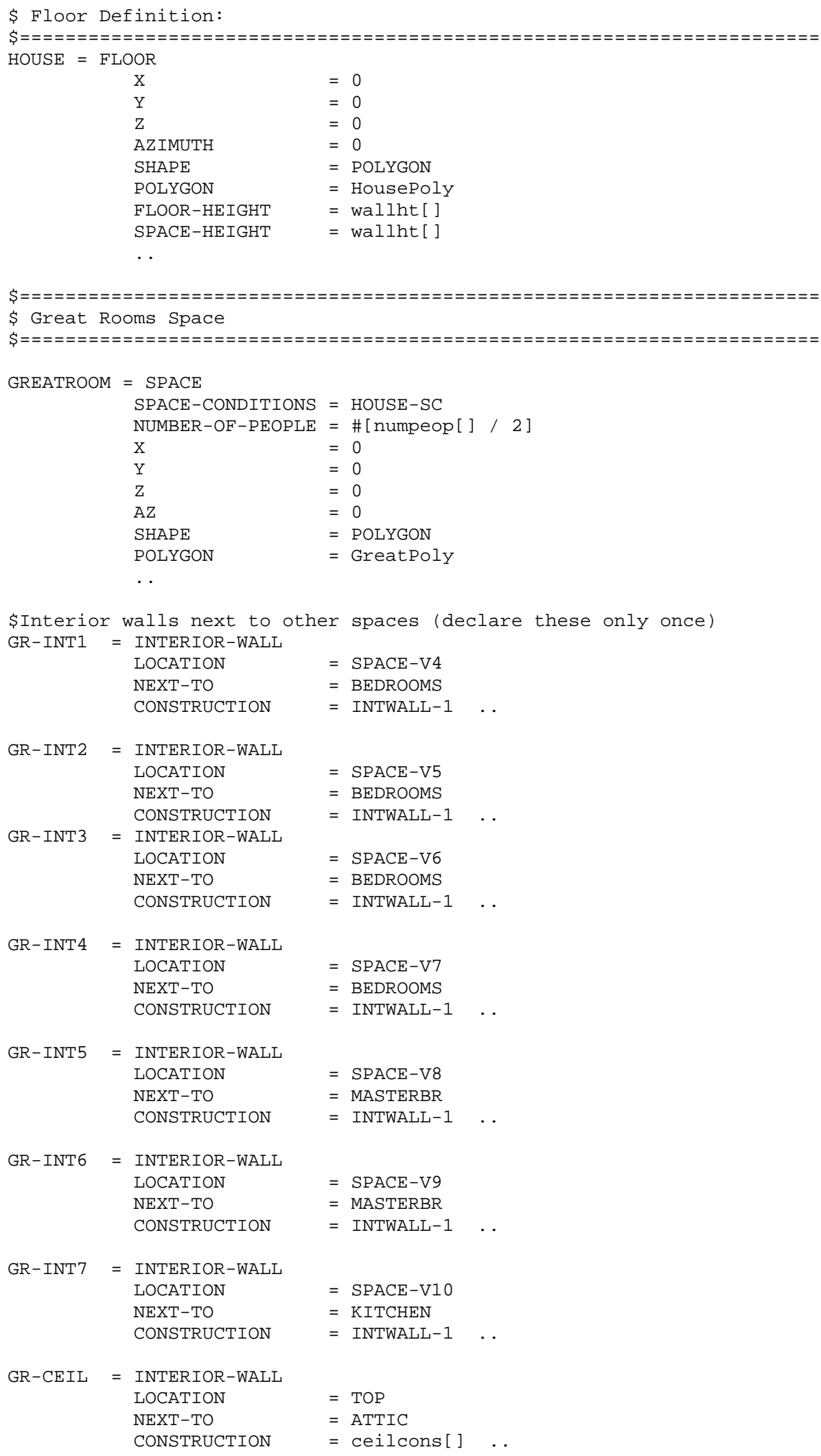




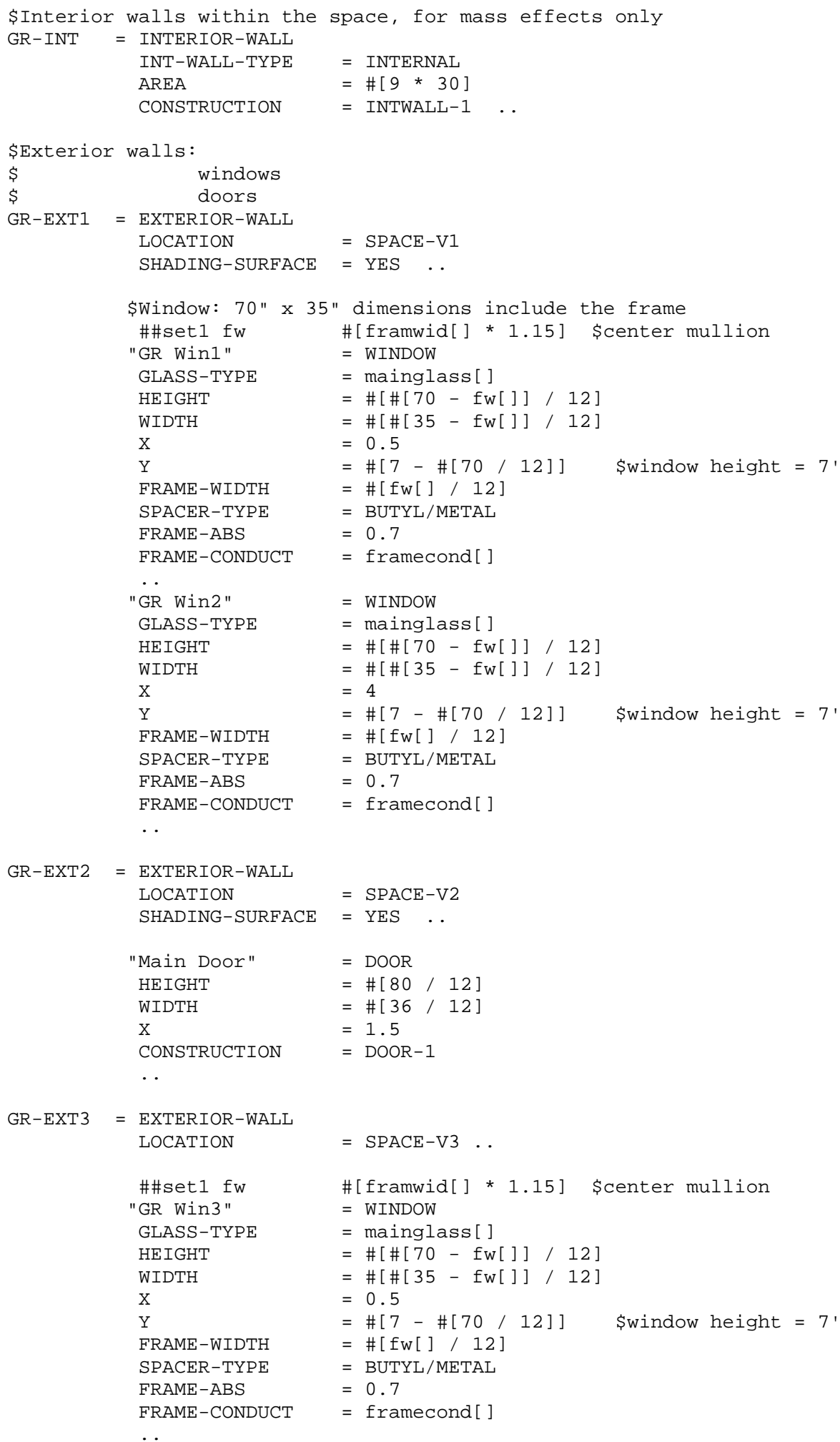




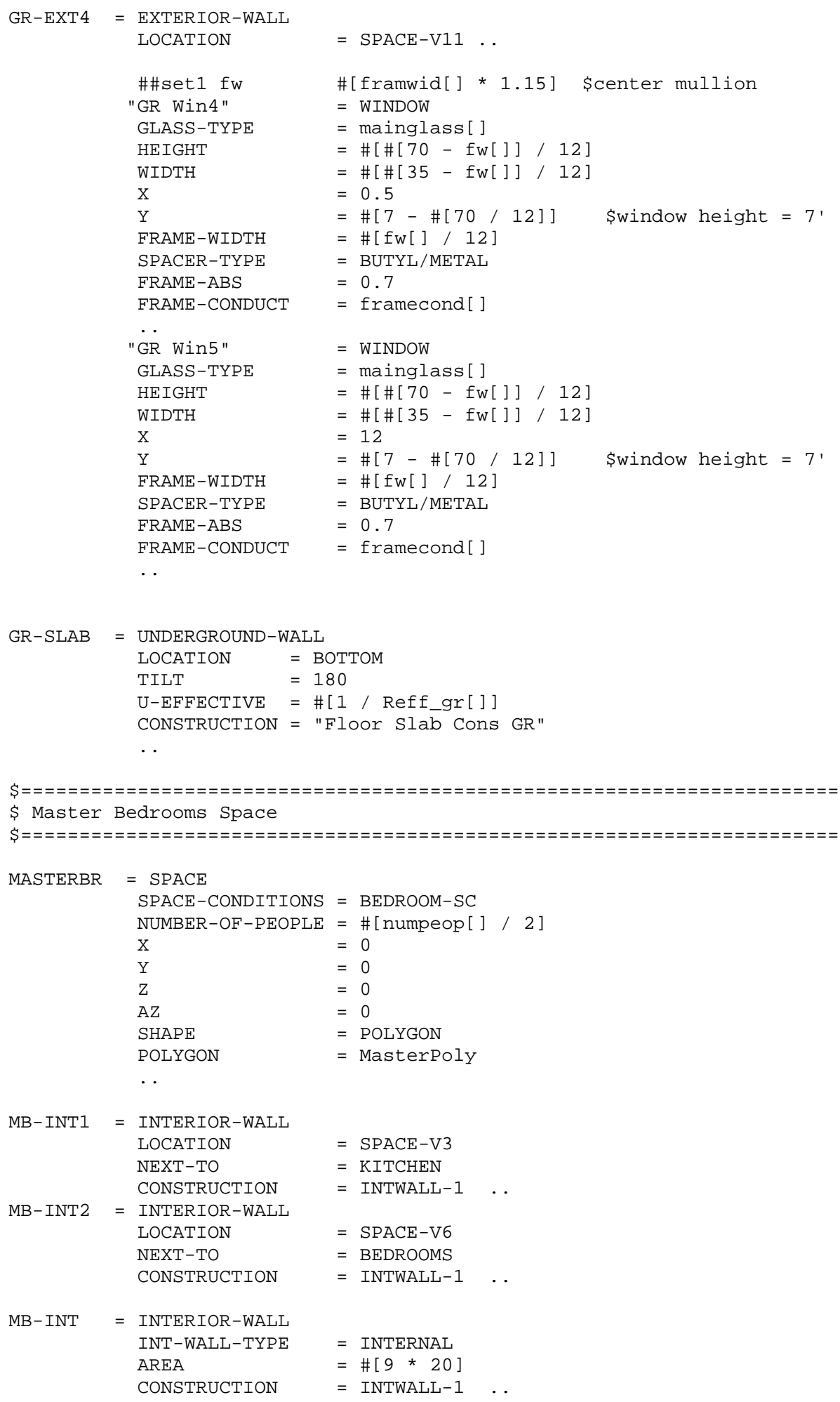




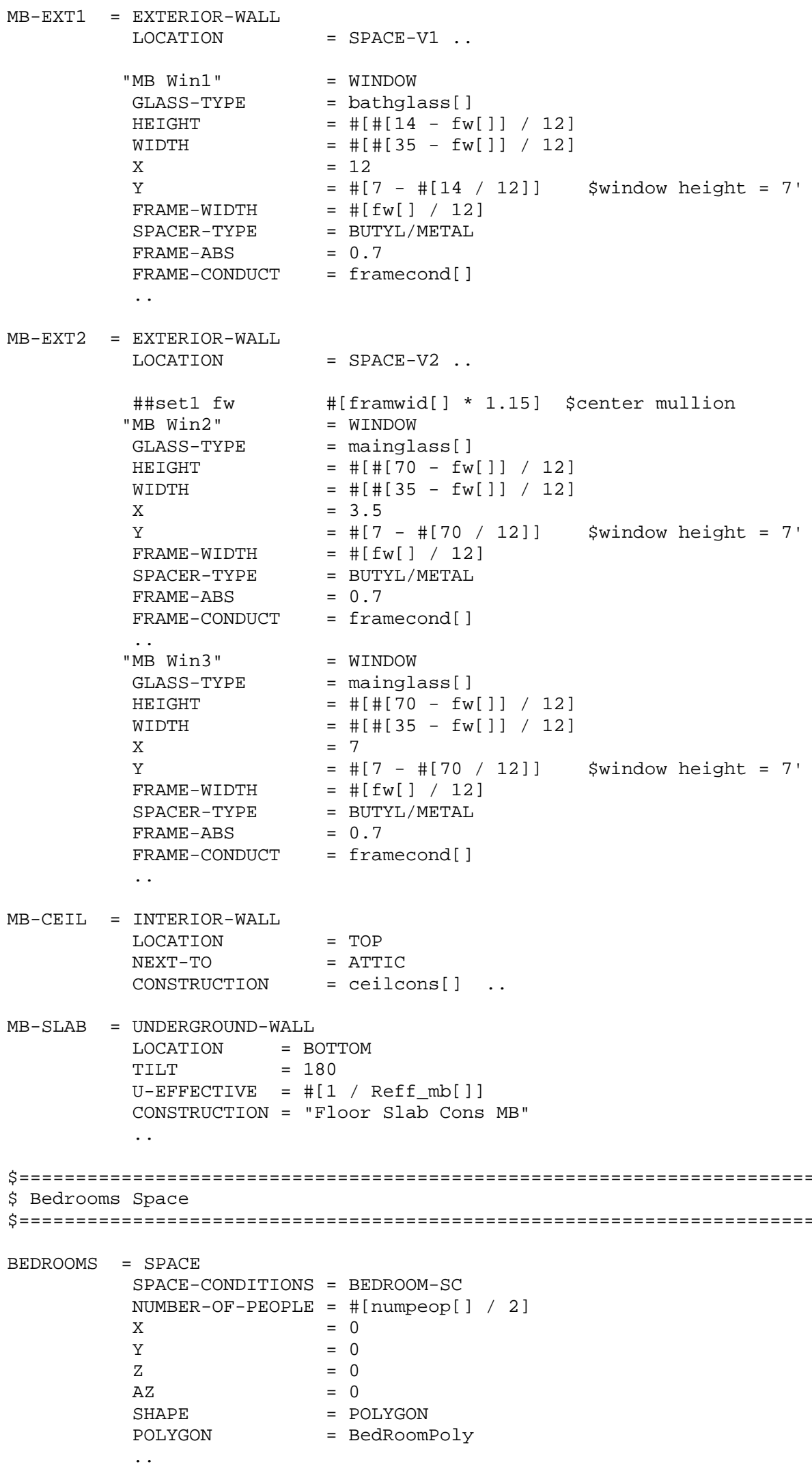




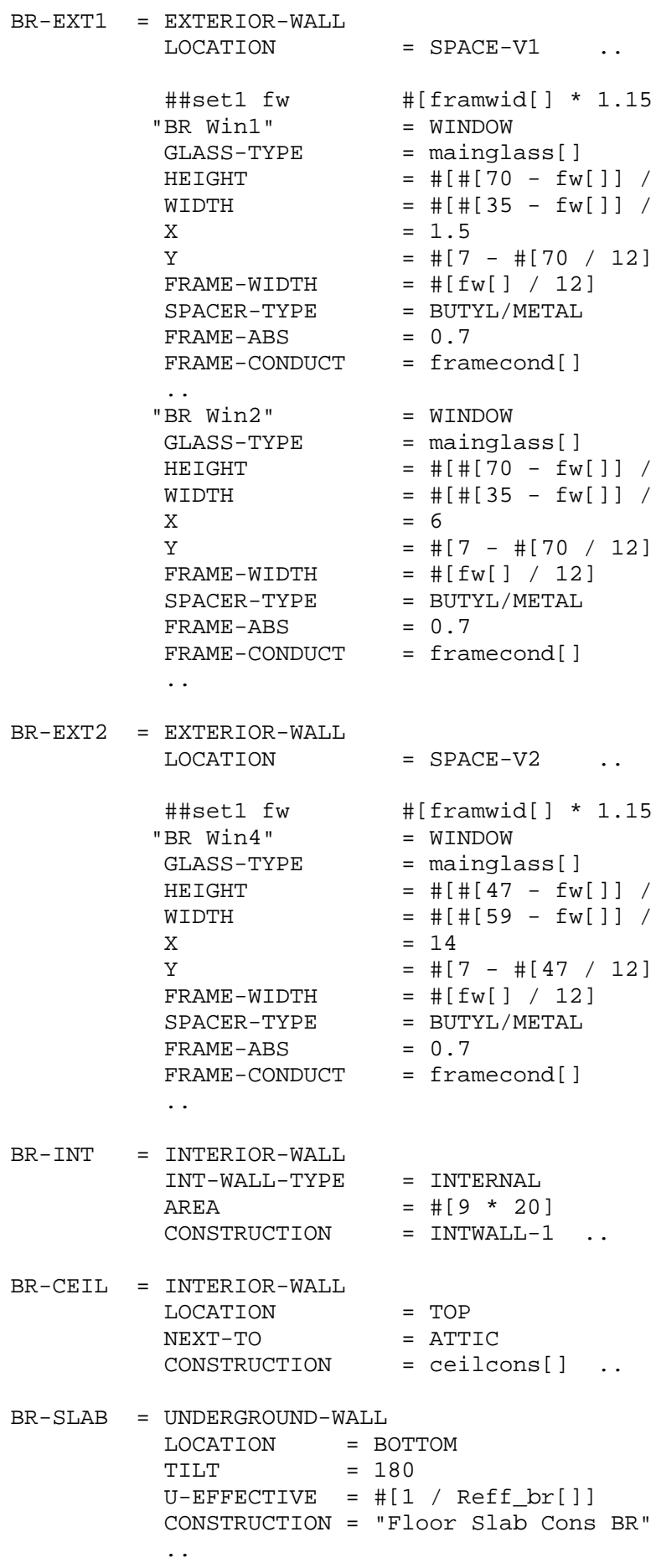




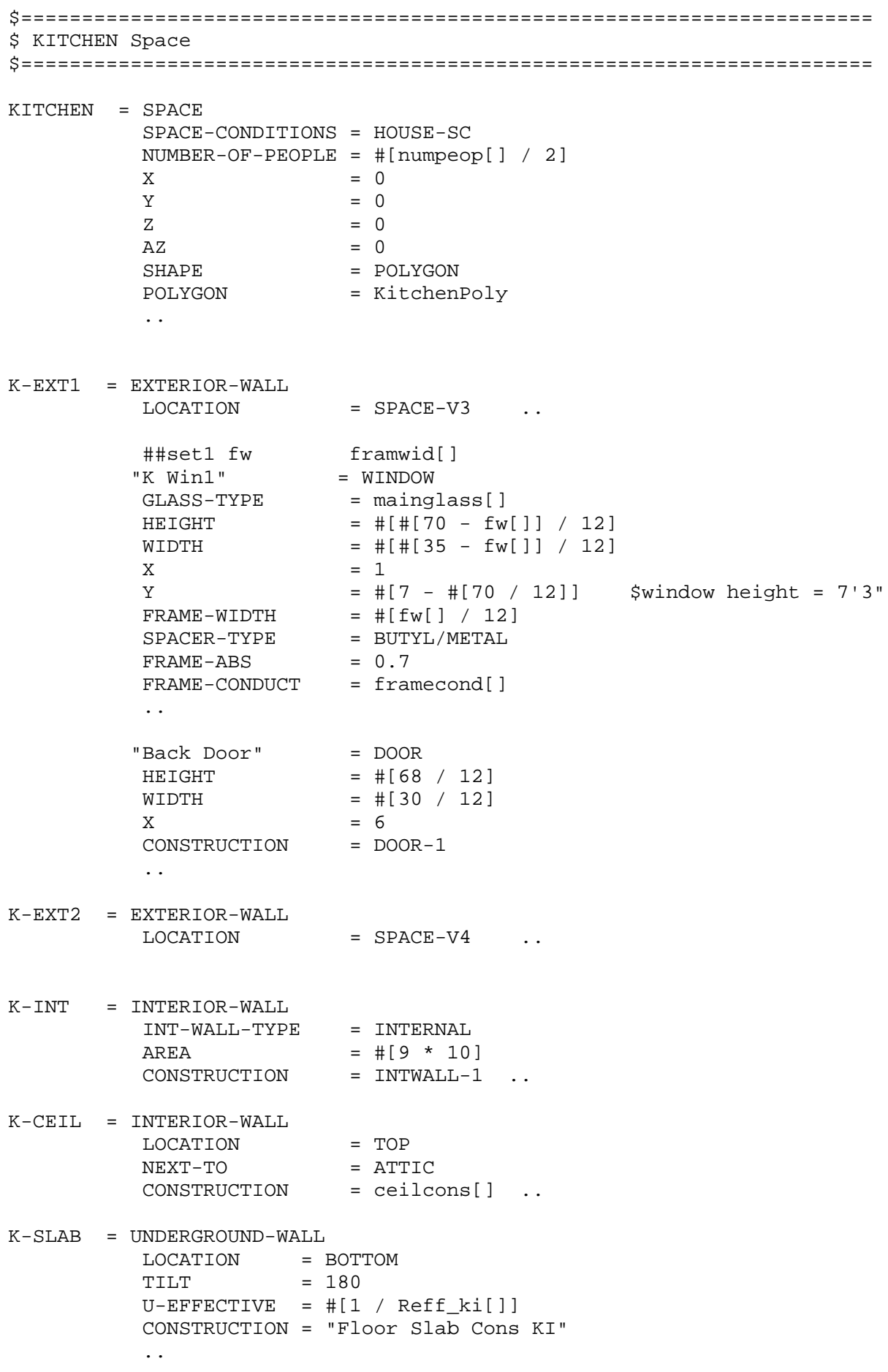




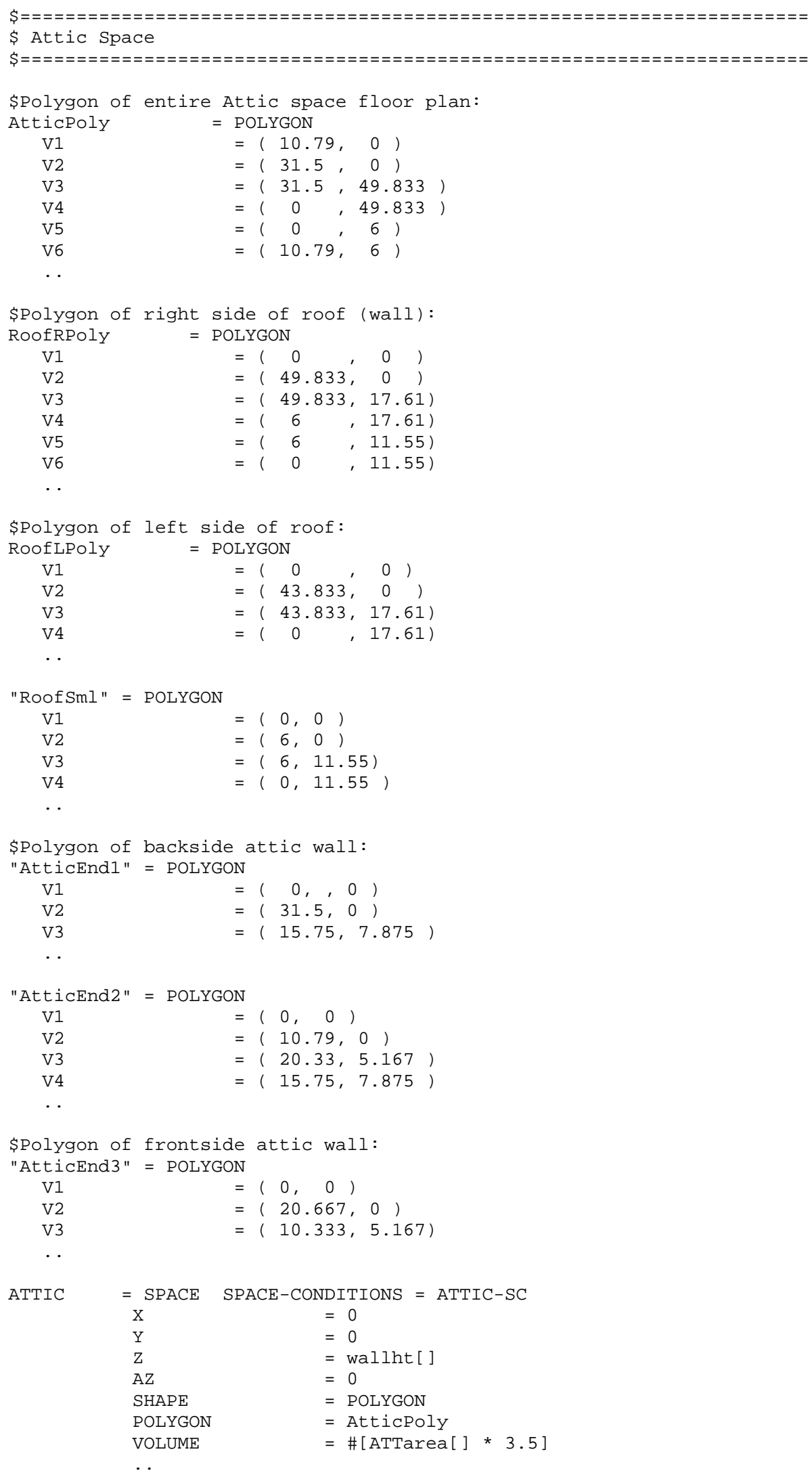




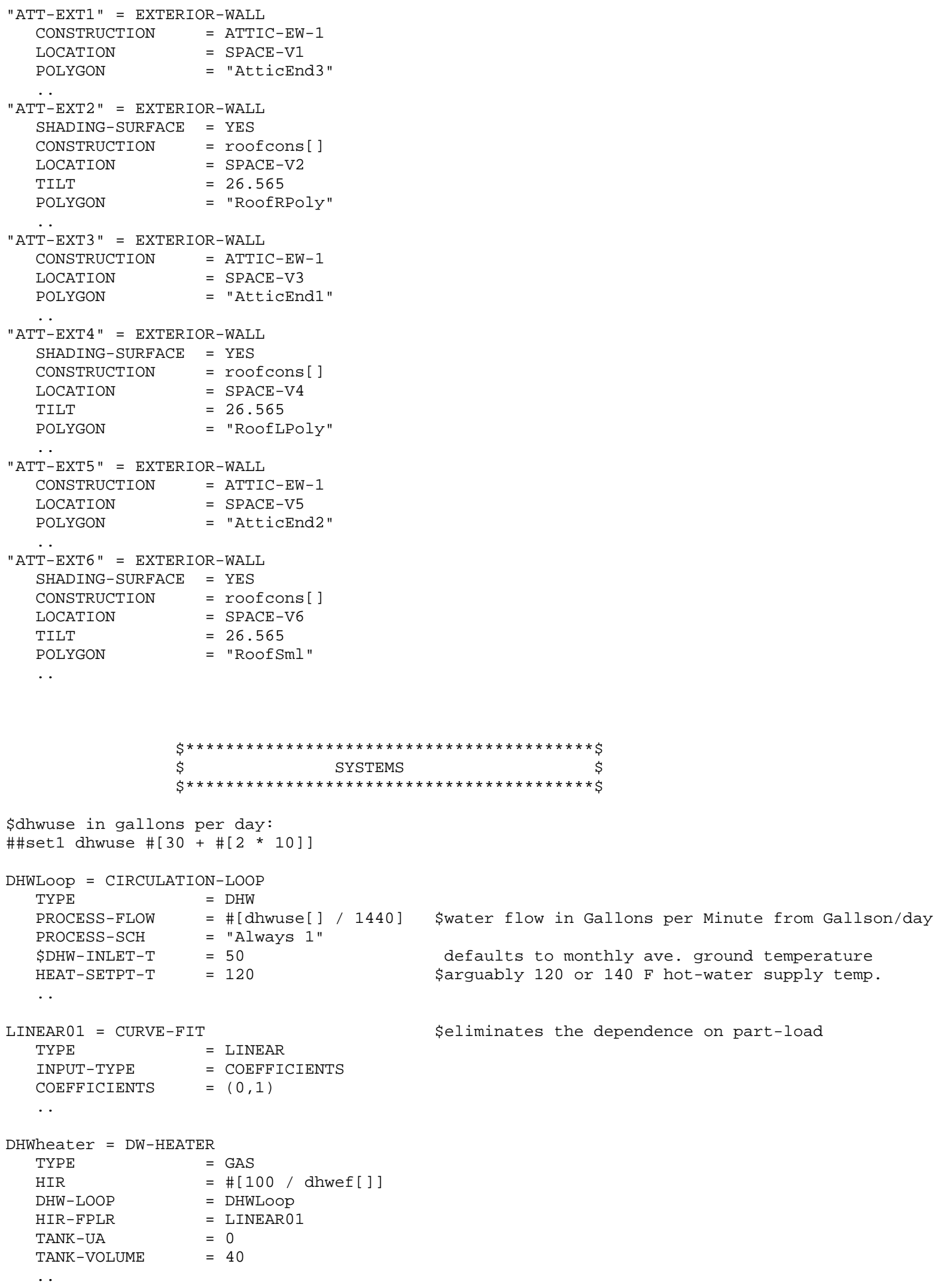




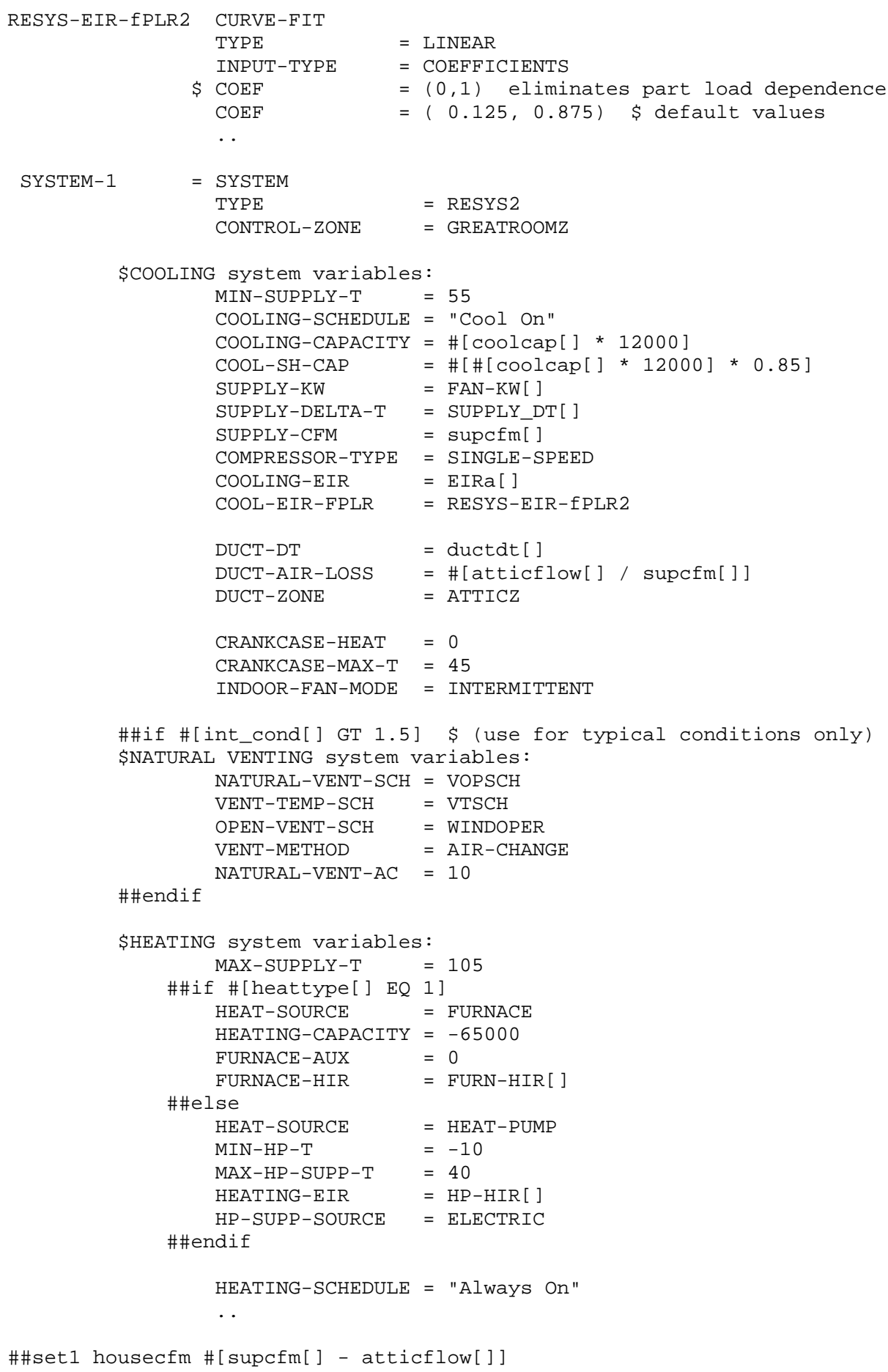




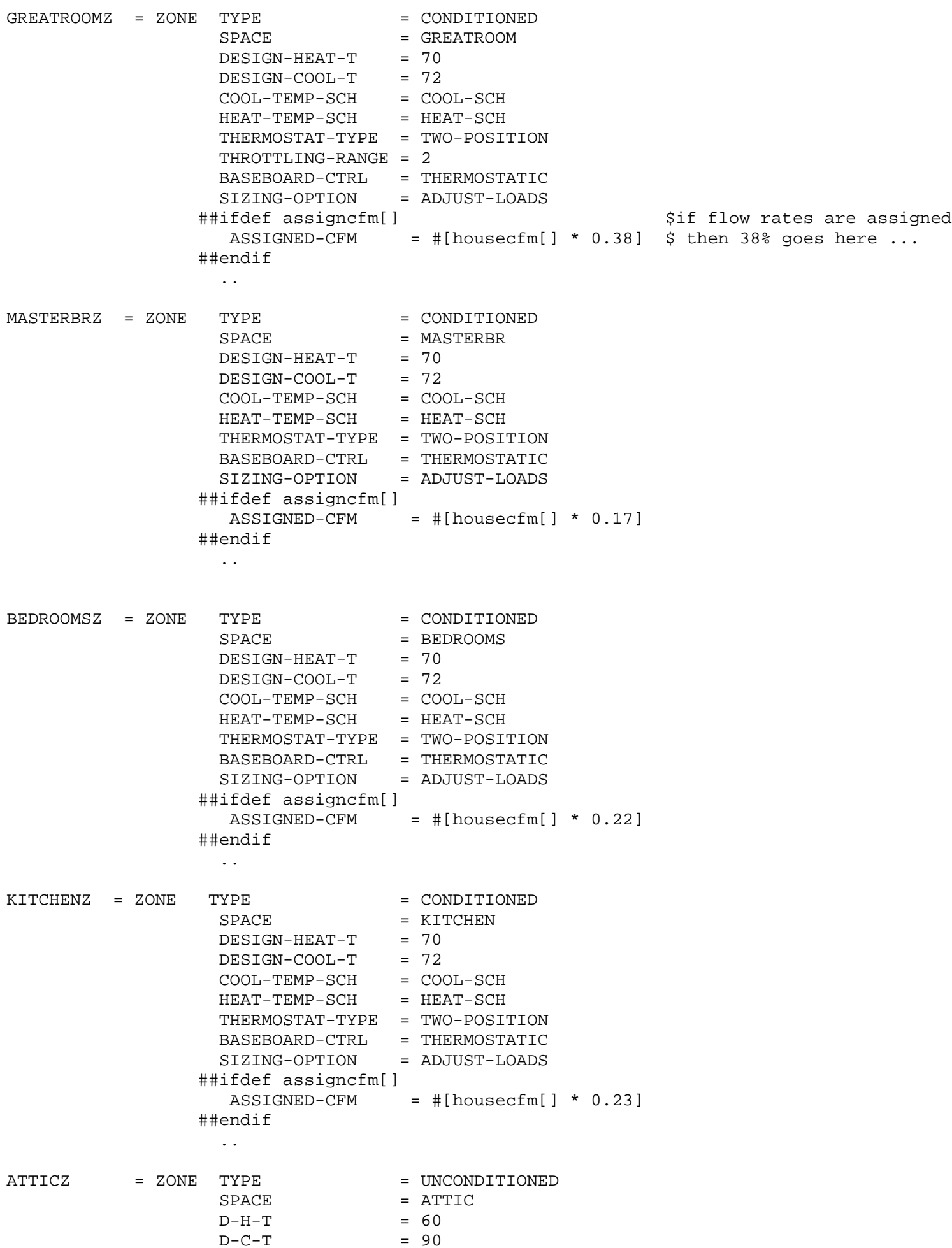




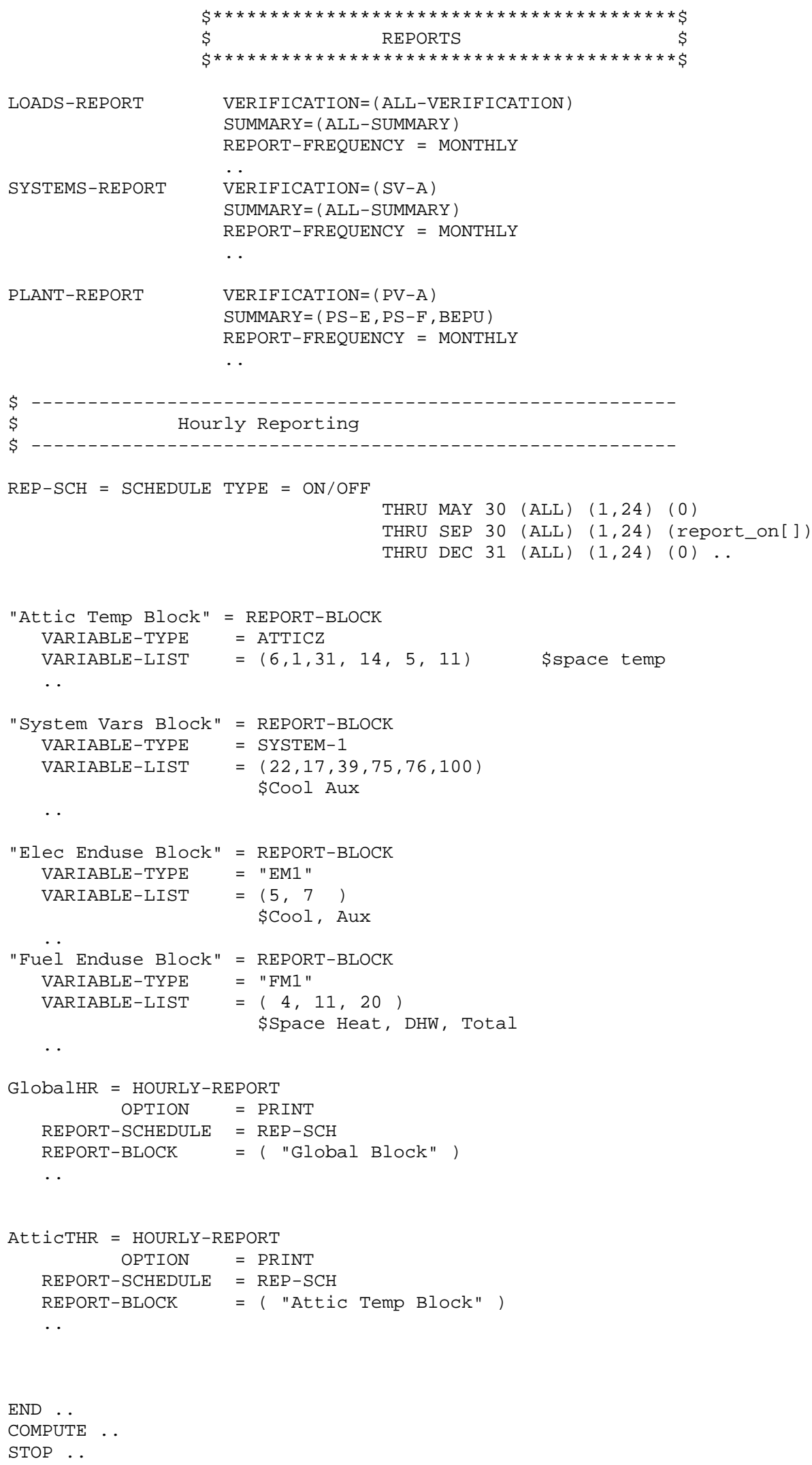




\section{Data file}

\$data file including EEMs and basic setup:

\$ Support file for Sample.INP

$\$$

\$ Sample Building America Model Home

\$ Created by Paul Reeves (PRC) for NREL

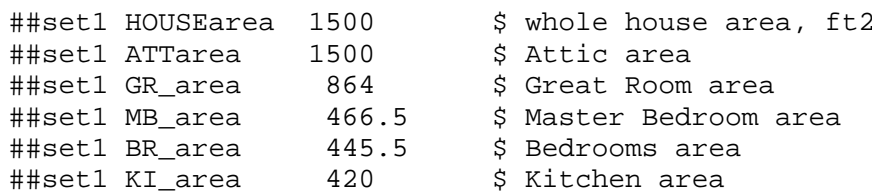

\$ perimeter lengths used for slab construction

\#\#set1 GR_perim_t 50 \$ Great Room

\#\#set1 MB_perim_t $40 \quad$ \$ Master Bedroom

\#\#set1 BR perim t $38 \quad$ \$ Bedrooms

\#\#set1 KI_perim_t 35 \$ Kitchen

\#\#set1 int_cond 2 \$Internal Conditions Flag: 1=testing, 2=typical

\#\#if \#[int_cond[] GT 1.5] $\$=====================>$ TYPICAL CONDITIONS

\#\#set1 intload \#[\#[\#[\#[HousEarea[] * 12.5] + 15000] / 34.13] / HousEarea[]]

\#\#set 1 winmanage 1 \$ window management used

\#\#set1 clsp1 $76 \quad$ \$ cooling setpoint: summer, evening/night

\#\#set1 clsp2 78 \$ cooling setpoint: summer, daytime, weekdays

\#\#set1 clsp3 77 \$ cooling setpoint: summer, daytime, weekends

\#\#set1 clsp4 $78 \quad$ \$ cooling setpoint: spring/fall, all the time

\#\#set 1 numpeop $4 \quad \$$ number of people in the house

\#\#set1 report_on 1 \$ hourly report on/off flag

\#\#set 1 htsp $\quad 70 \quad$ \$ heat setpoint in degrees $\mathrm{F}$

\#\#set1 htsb $67 \quad$ Sheat setback in delta degrees $F$

\#\# \#se

$\$==========================>$ TESTING CONDITIONS

\#\#set1 intload \#[100 / HousEarea[]] \$ minimal internal load (100 watts)

\#\#set 1 winmanage $0 \quad$ \$ window management not used

\#\#set1 clsp1 $76 \quad$ \$ cooling setpoint

\#\#set1 clsp2 $\quad 76 \quad$ cooling setpoint

\#\#set1 clsp3 $76 \quad$ \$ cooling setpoint

\#\#set1 clsp4 $76 \quad$ \$ cooling setpoint

\#\#set 1 numpeop $0 \quad \$$ number of people in the house

\#\#set1 report_on 1 \$ hourly report on/off flag

\#\#set 1 htsp $\quad 70 \quad$ \$ heat setpoint in degrees $\mathrm{F}$

\#\#set 1 htsb $\quad 70 \quad \$$ heat setback in delta degrees $F$

\#\#endif

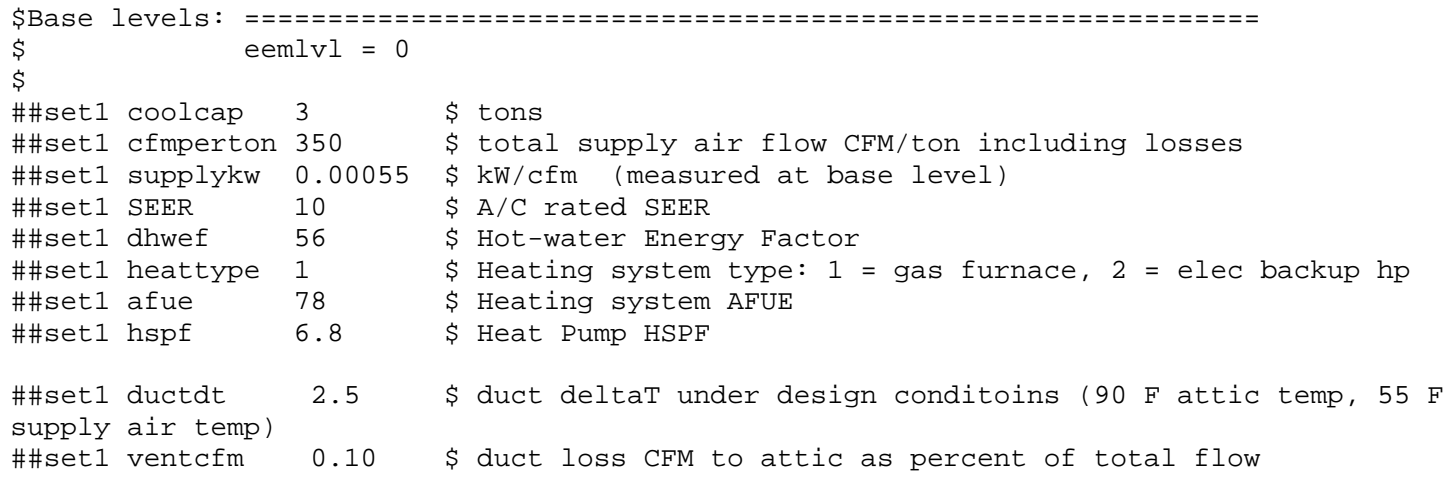




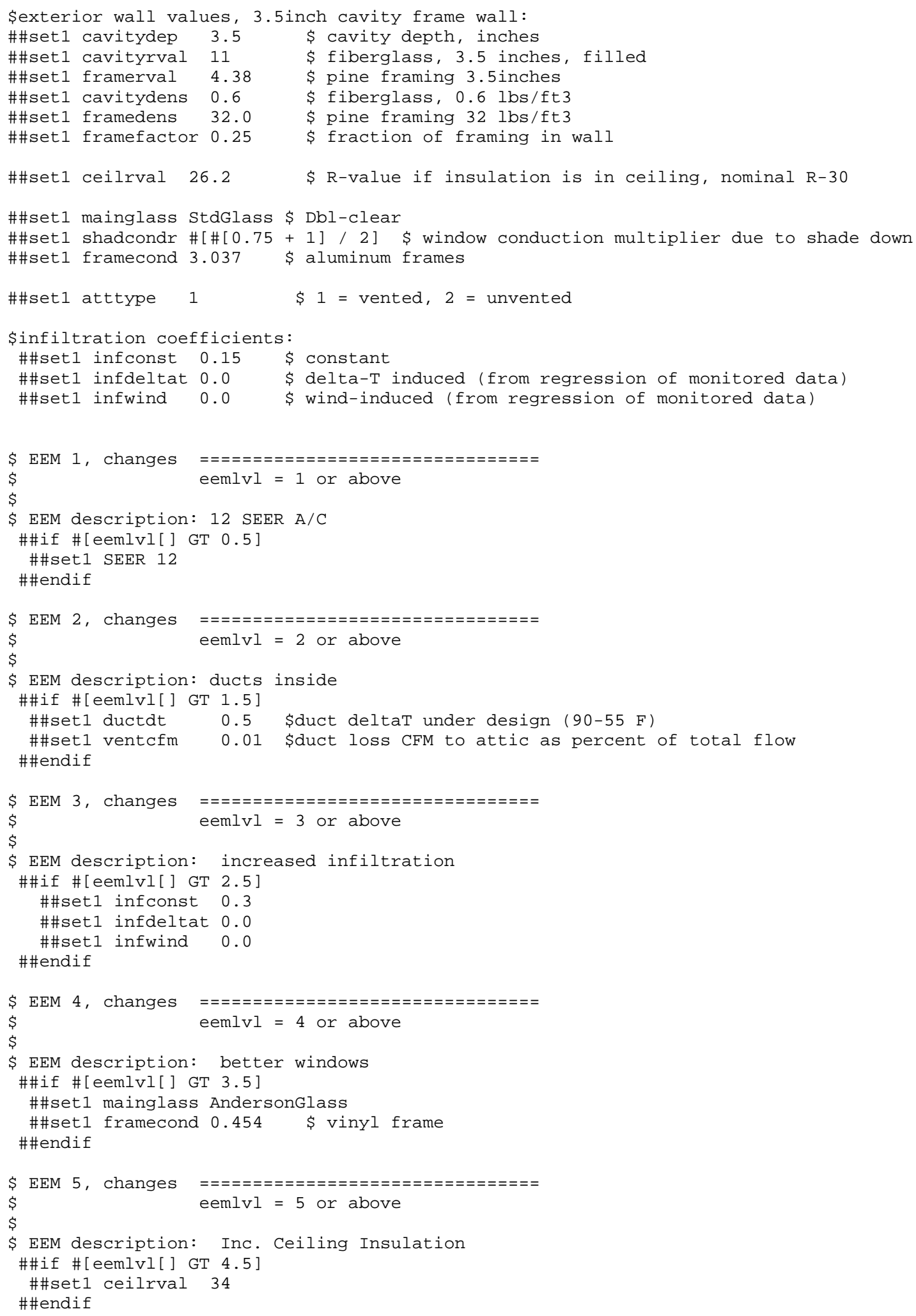




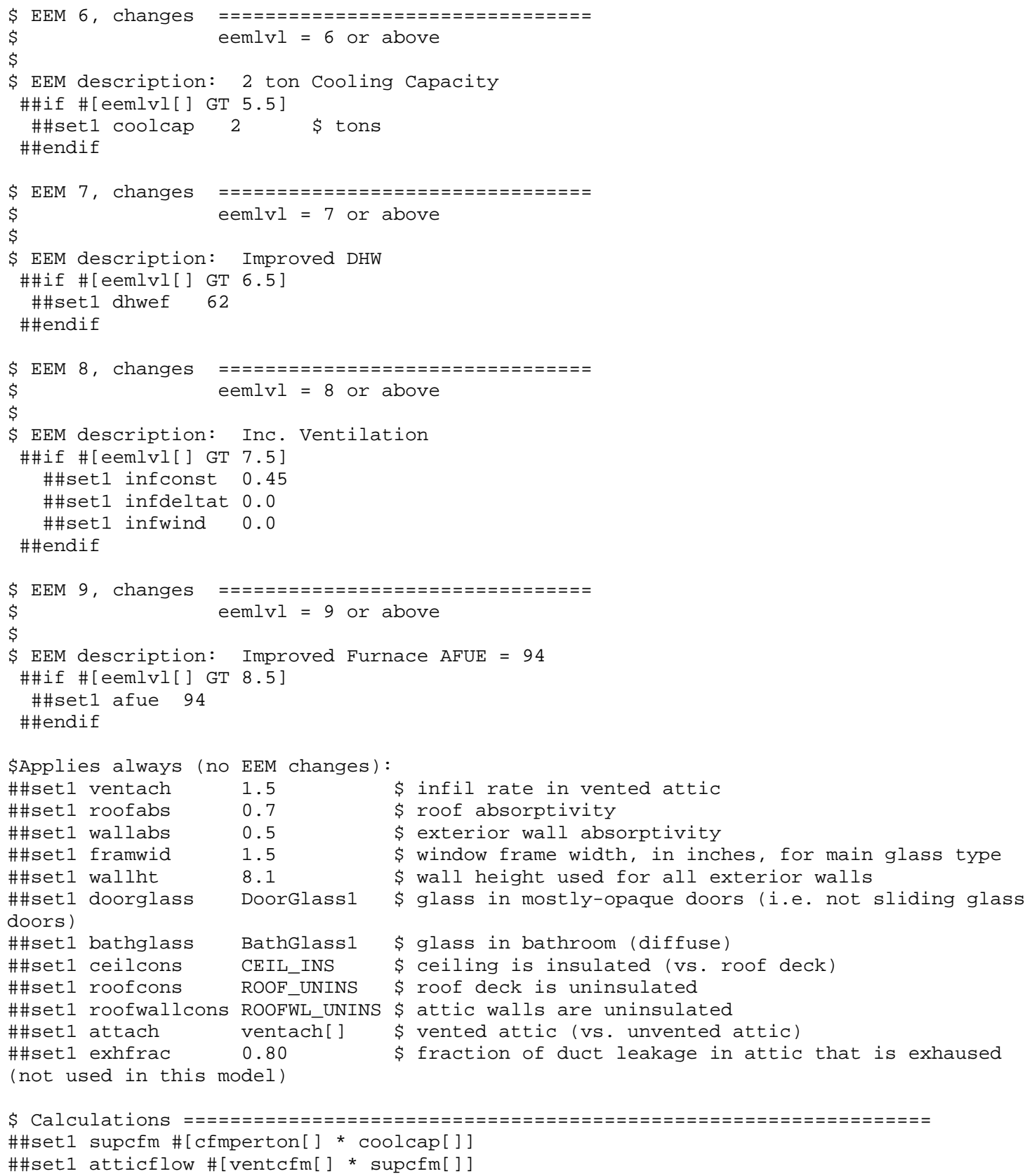




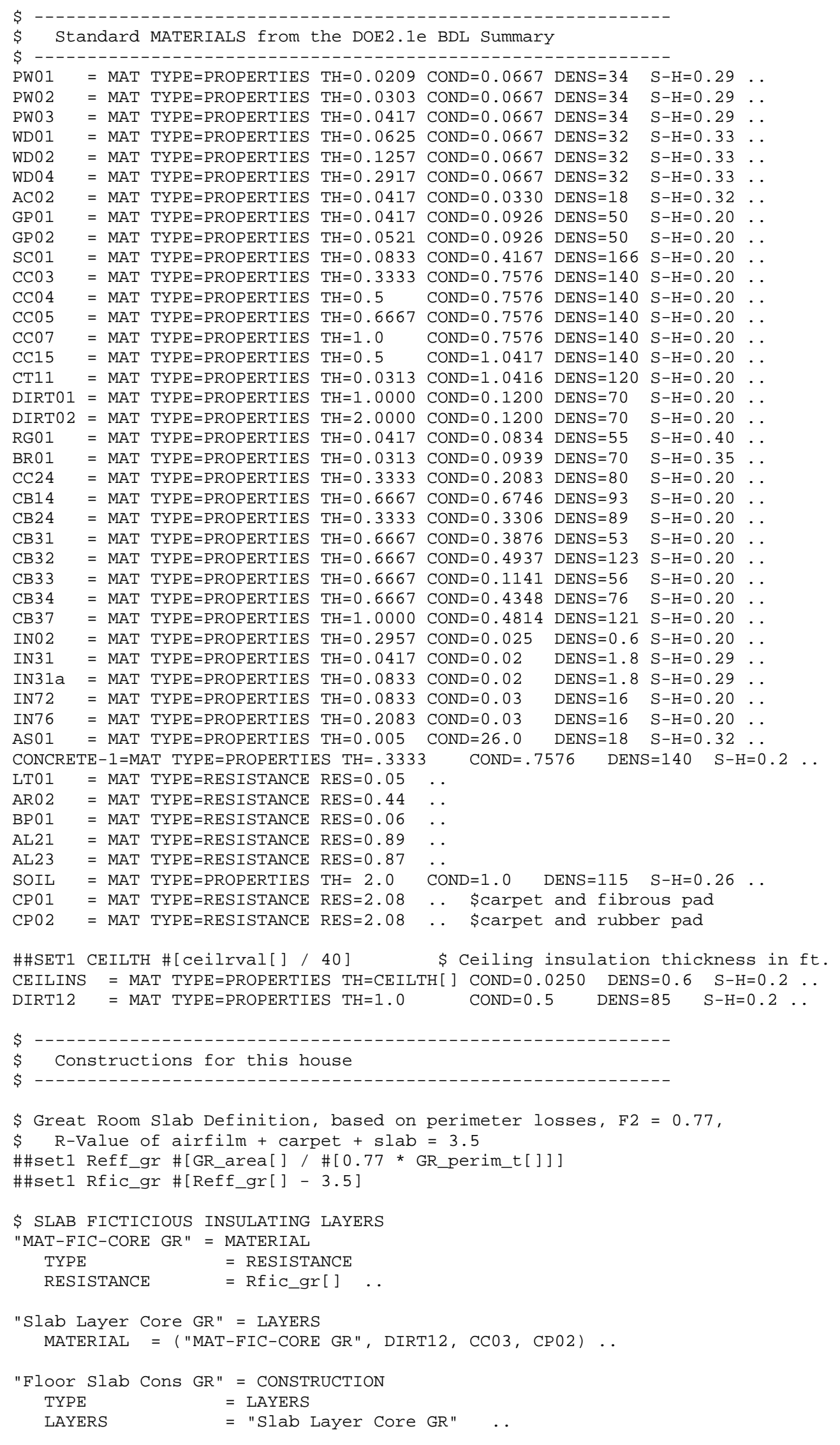




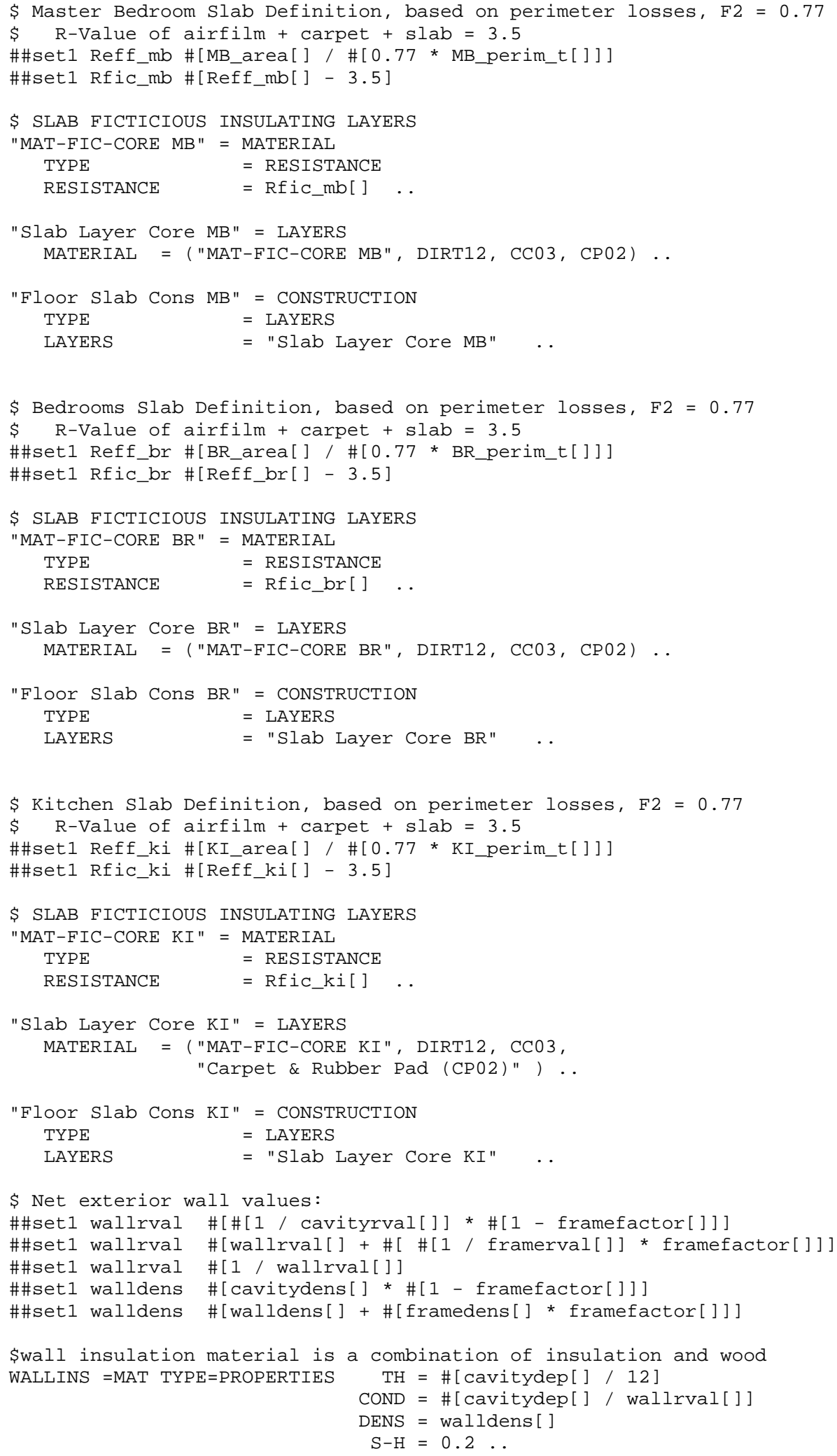




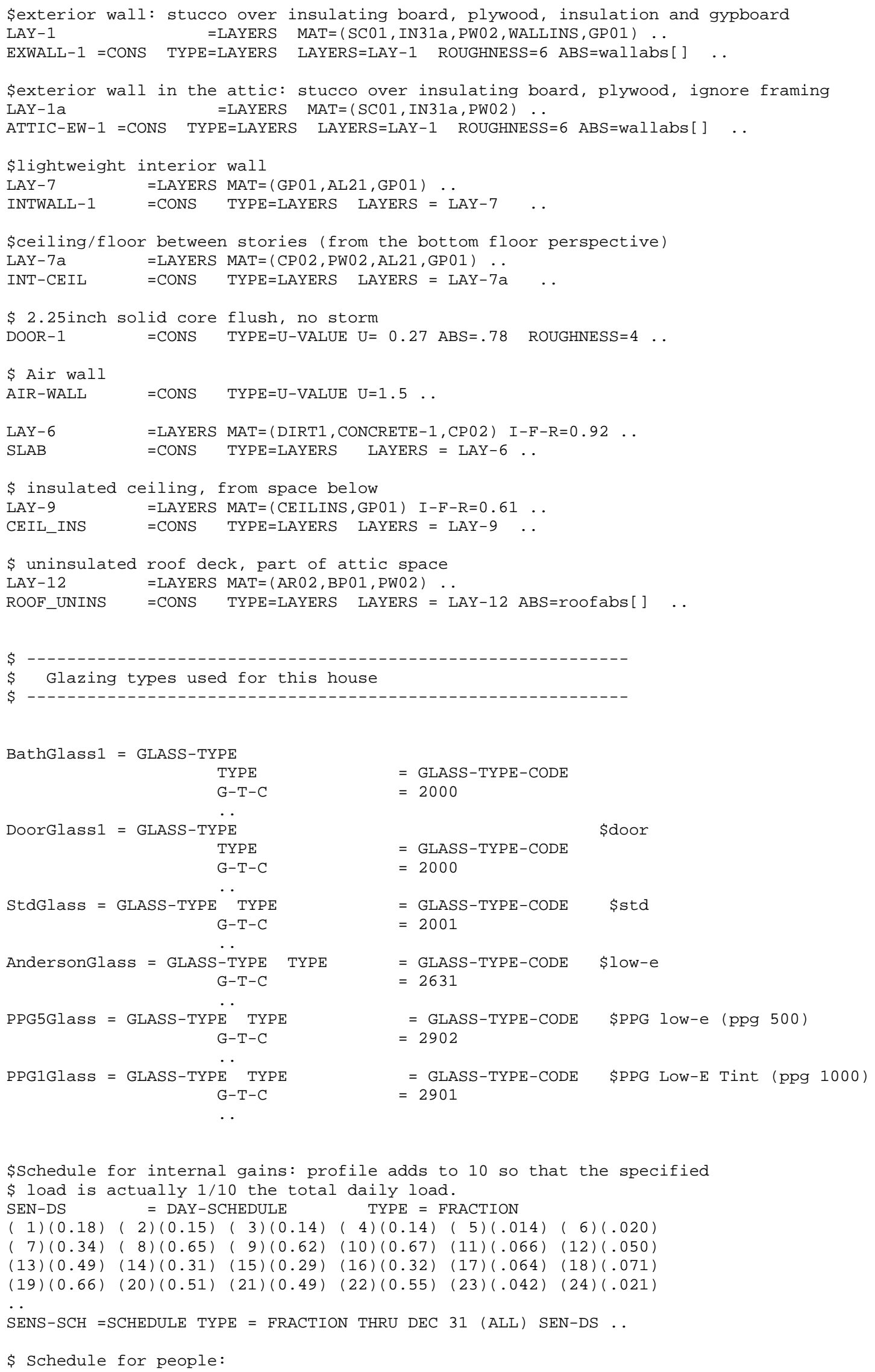




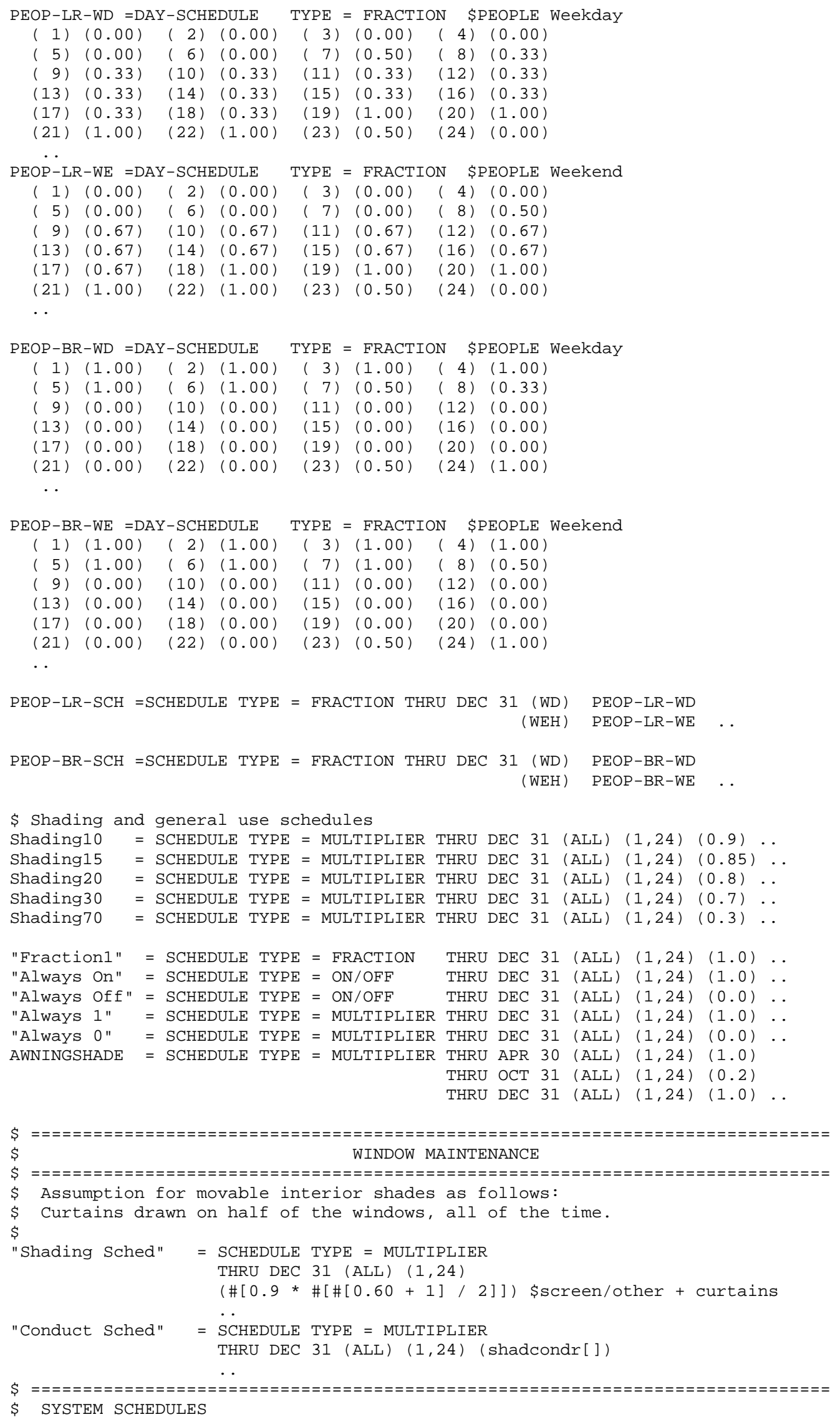

$\$$ SYSTEM SCHEDULES 


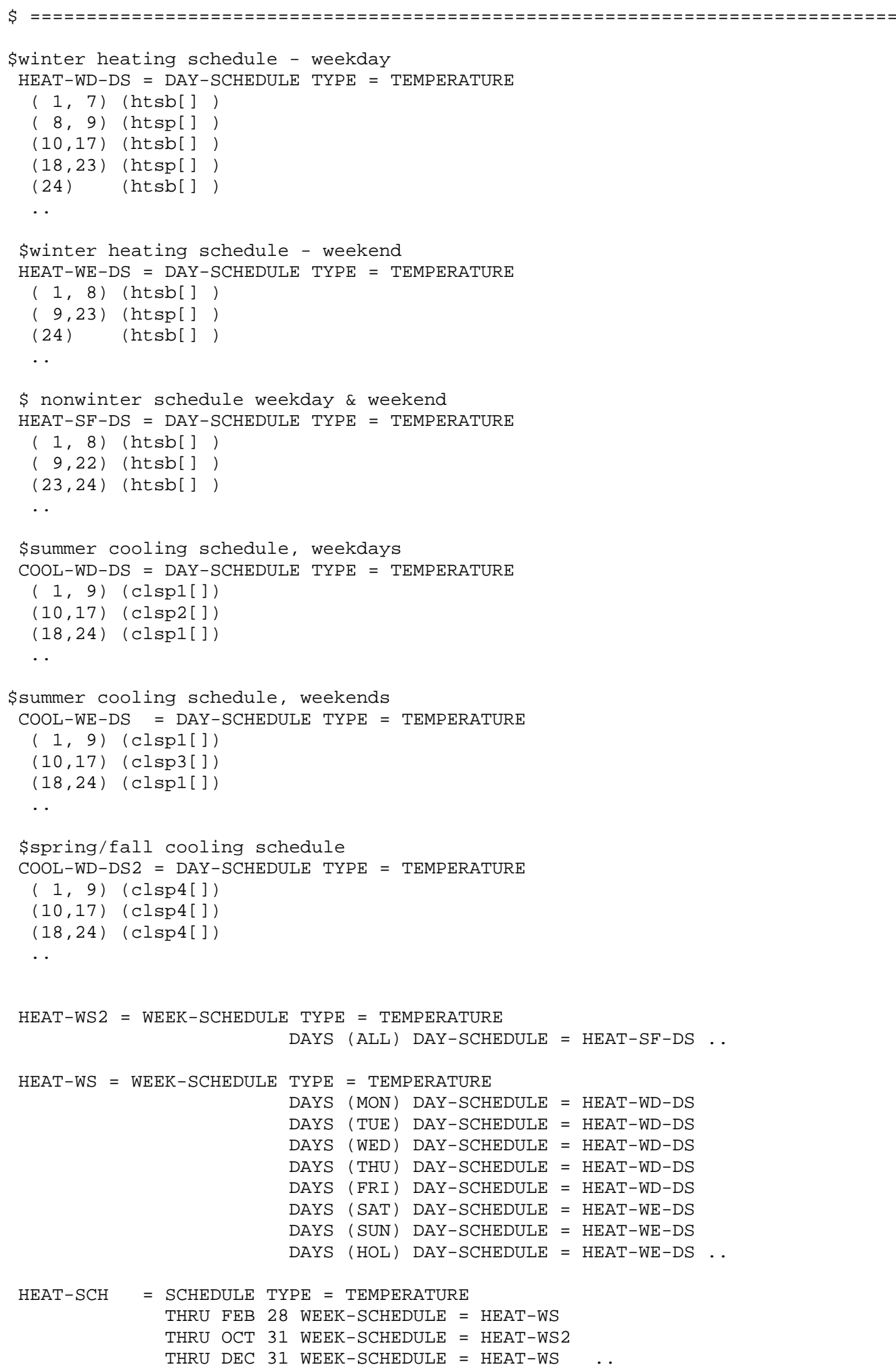




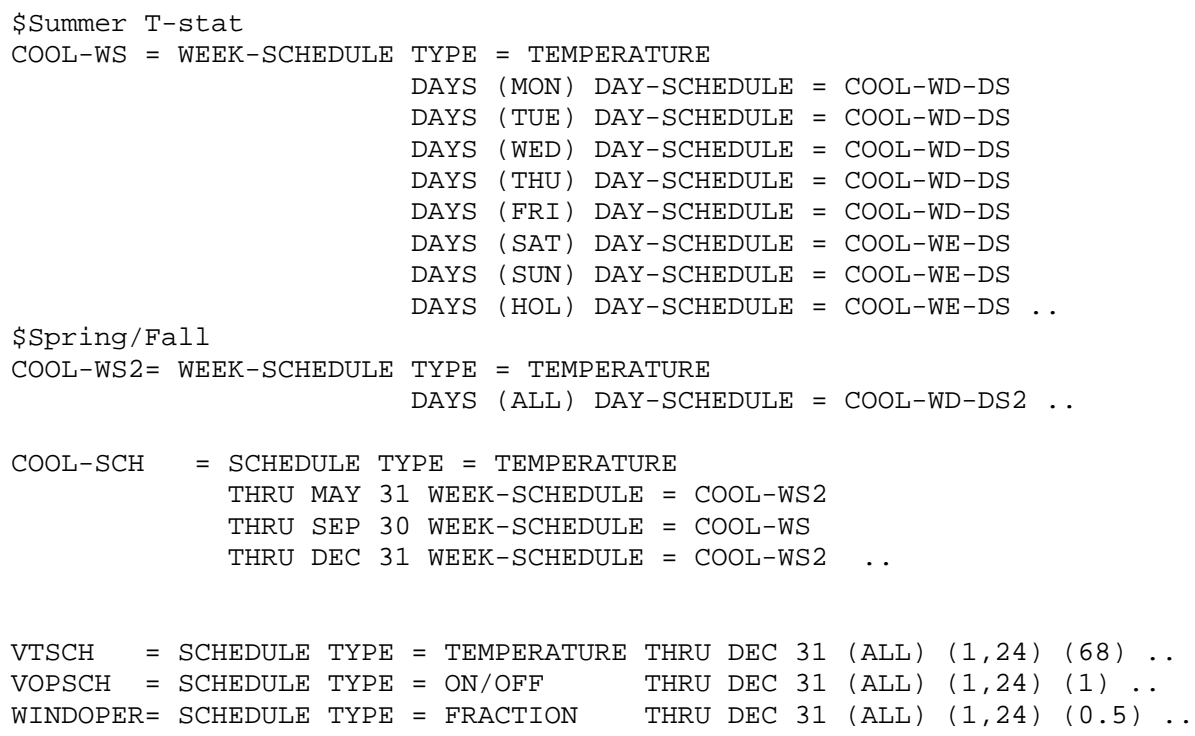




\section{Example DOE-2.2 Standard Reports}

Verification reports summarize the information given to the program. A quick check of these reports can verify that the proper data have been input.

REPORT- LV-B Summary of Spaces Occurring in the Project WEATHER FILE- San Antonio TX TMY2

NUMBER OF SPACES

5

EXTERIOR

INTERIOR

SPACE

FLOOR

SPACE*FLOOR SPACE

LIGHTS

MULTIPLIER TYPE

(WATT

SQFT )

METHOD

$\mathrm{ACH}$

AREA

VOLUME

GREATROOM HOUSE

MASTERBR HOUSE

BEDROOMS HOUSE

KITCHEN HOUSE

ATTIC

HOUSE

$\begin{array}{ll}1.0 & \text { EXT } \\ 1.0 & \text { EXT } \\ 1.0 & \text { EXT } \\ 1.0 & \text { EXT } \\ 1.0 & \text { EXT }\end{array}$

$0.0 \quad 0.00$

0.00
0.00
0.00
0.00
0.00

$2.0 \quad 0.83$

0.83 RESIDENTIA 0.00

RESIDENTIA 0.00

RESIDENTIA 0.00

606.5

(CUFT )

BUILDING TOTALS

$\begin{array}{lll}0.83 & \text { RESIDENTIA } & 0.00 \\ 0.83 & \text { RESIDENTIA } & 0.00\end{array}$

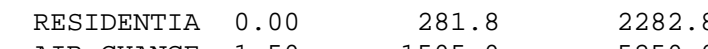

8.0

AIR-CHANGE $1.50 \quad 1505.0$

5250.0 
INTERIOR SURFACES (U-VALUE INCLUDES BOTH AIR FILMS)

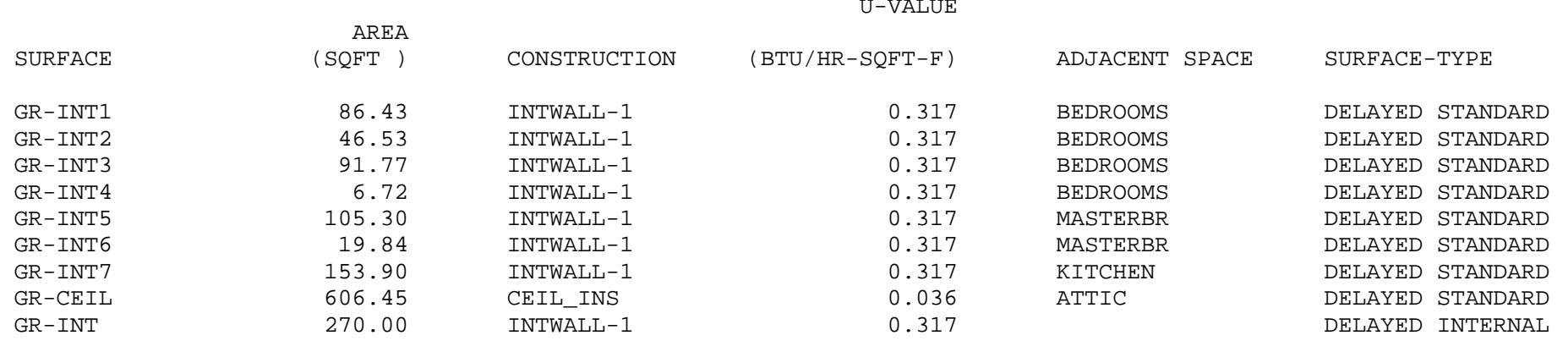

EXTERIOR SURFACES (U-VALUE EXCLUDES OUTSIDE AIR FILM)

\begin{tabular}{|c|c|c|c|c|c|c|c|}
\hline \multirow[b]{2}{*}{ SURFACE } & \multirow[b]{2}{*}{ MULTIPLIER } & \multirow[b]{2}{*}{$\begin{array}{r}\text { AREA } \\
\text { (SQFT ) }\end{array}$} & \multirow[b]{2}{*}{$\begin{array}{r}\text { WIDTH } \\
\text { (FT) }\end{array}$} & \multirow[b]{2}{*}{$\begin{array}{r}\text { HEIGHT } \\
(\mathrm{FT})\end{array}$} & \multicolumn{3}{|c|}{ U-VALUE } \\
\hline & & & & & CONSTRUCTION & $(\mathrm{BTU} / \mathrm{HR}-\mathrm{SQFT}-\mathrm{F})$ & $\begin{array}{l}\text { SURFACE } \\
\text { TYPE }\end{array}$ \\
\hline GR-EXT1 & 1.0 & 87.40 & 10.79 & 8.10 & EXWALL-1 & 0.149 & DELAYED \\
\hline GR-EXT2 & 1.0 & 48.60 & 6.00 & 8.10 & EXWALL-1 & 0.149 & DELAYED \\
\hline $\mathrm{GR}-\mathrm{EXT} 3$ & 1.0 & 33.09 & 4.09 & 8.10 & EXWALL-1 & 0.149 & DELAYED \\
\hline GR-EXT 4 & 1.0 & 234.90 & 29.00 & 8.10 & EXWALL-1 & 0.149 & DELAYED \\
\hline
\end{tabular}

UNDERGROUND SURFACES (U-VALUE INCLUDES INSIDE AIR FILM)

$\begin{array}{lrrlr}\text { SURFACE } & \text { MULTIPLIER } & \begin{array}{c}\text { AREA } \\ \text { (SQFT })\end{array} & \text { CONSTRUCTION } & \begin{array}{r}\text { U-VALUE } \\ \text { GR-SLAB }\end{array} \\ \text { (BTU/HR-SQFT-F) }\end{array}$




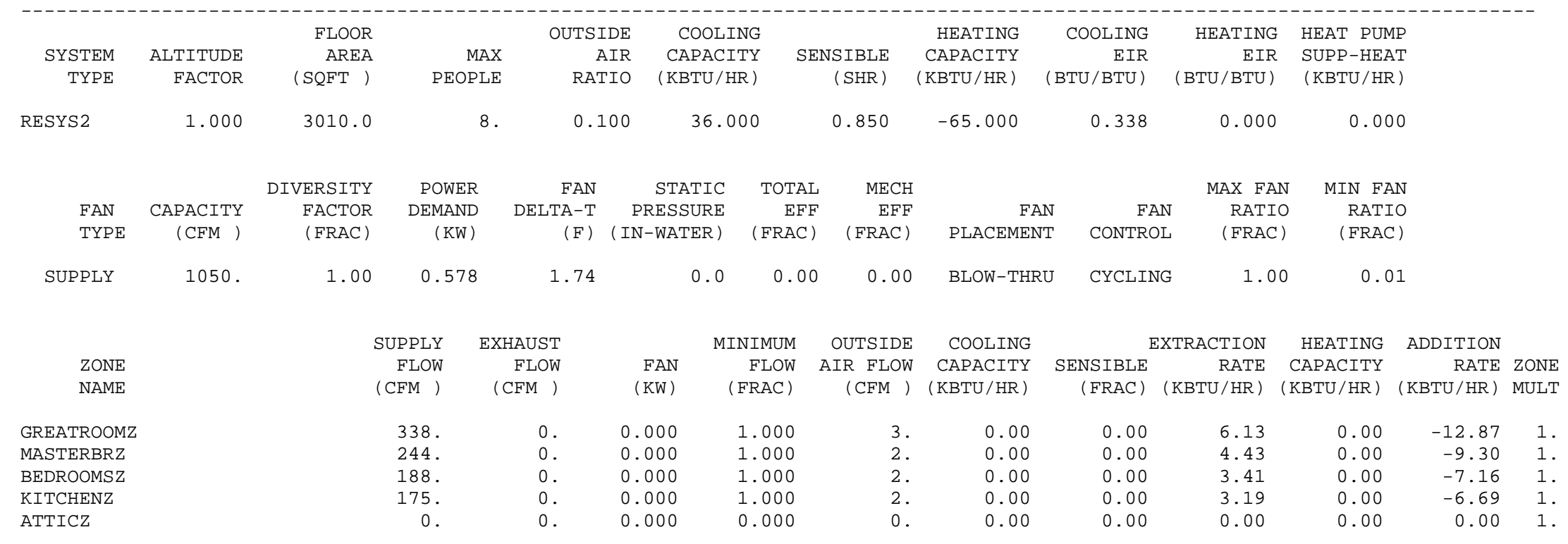


$\star * \star$ BUILDING $* * *$

$\begin{array}{lrlll}\text { FLOOR AREA } & 1429 & \text { SQFT } & 133 & \text { M2 } \\ \text { VOLUME } & 15512 & \text { CUFT } & 439 & \text { M3 }\end{array}$

\section{TIME}

DRY-BULB TEMP

WET-BULB TEMP

TOT HORIZONTAL SOLAR RAD

WINDSPEED AT SPACE

CLOUD AMOUNT 0 (CLEAR) -10

\begin{tabular}{|c|c|c|c|c|}
\hline & SEI & JSIBLE & LAT & ENT \\
\hline & $(\mathrm{KBTU} / \mathrm{H})$ & $(\mathrm{KW})$ & $(\mathrm{KBTU} / \mathrm{H})$ & $(\mathrm{KW})$ \\
\hline WALL CONDUCTION & 4.541 & 1.330 & 0.000 & 0.000 \\
\hline ROOF CONDUCTION & 0.000 & 0.000 & 0.000 & 0.000 \\
\hline WINDOW GLASS+FRM COND & 4.833 & 1.416 & 0.000 & 0.000 \\
\hline WINDOW GLASS SOLAR & 8.874 & 2.600 & 0.000 & 0.000 \\
\hline DOOR CONDUCTION & 0.411 & 0.121 & 0.000 & 0.000 \\
\hline INTERNAL SURFACE COND & 0.000 & 0.000 & 0.000 & 0.000 \\
\hline UNDERGROUND SURF COND & -0.218 & -0.064 & 0.000 & 0.000 \\
\hline OCCUPANTS TO SPACE & 2.768 & 0.811 & 2.100 & 0.615 \\
\hline LIGHT TO SPACE & 0.000 & 0.000 & 0.000 & 0.000 \\
\hline EQUIPMENT TO SPACE & 2.041 & 0.598 & 0.586 & 0.172 \\
\hline PROCESS TO SPACE & 0.000 & 0.000 & 0.000 & 0.000 \\
\hline INFILTRATION & 3.191 & 0.935 & 2.839 & 0.832 \\
\hline TOTAL & 26.440 & 7.747 & 5.525 & 1.619 \\
\hline TOTAL / AREA & 0.019 & 0.058 & 0.004 & 0.012 \\
\hline TOTAL LOAD & 31.965 & $\mathrm{KBTU} / \mathrm{H}$ & 9.366 & KW \\
\hline TOTAL LOAD / AREA & 22.37 & $\mathrm{BTU} / \mathrm{H} . \mathrm{SQFT}$ & 70.538 & W/M2 \\
\hline
\end{tabular}

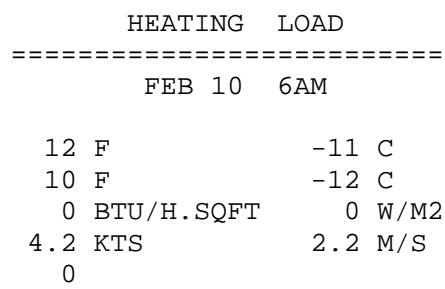

SENSIBLE

\begin{tabular}{|c|c|}
\hline (KBTU/H) & ( $\mathrm{KW})$ \\
\hline-6.120 & -1.793 \\
\hline 0.000 & 0.000 \\
\hline-6.667 & -1.953 \\
\hline 0.271 & 0.079 \\
\hline-0.452 & -0.132 \\
\hline 0.000 & 0.000 \\
\hline-1.559 & -0.457 \\
\hline 3.003 & 0.880 \\
\hline 0.000 & 0.000 \\
\hline 0.632 & 0.185 \\
\hline 0.000 & 0.000 \\
\hline-14.576 & -4.271 \\
\hline-25.468 & -7.462 \\
\hline-0.018 & -0.056 \\
\hline
\end{tabular}

$-25.468 \mathrm{KBTU} / \mathrm{H} \quad-7.462 \mathrm{KW}$

$17.820 \mathrm{BTU} / \mathrm{H} . \mathrm{SQFT} \quad 56.200$ W/M2 


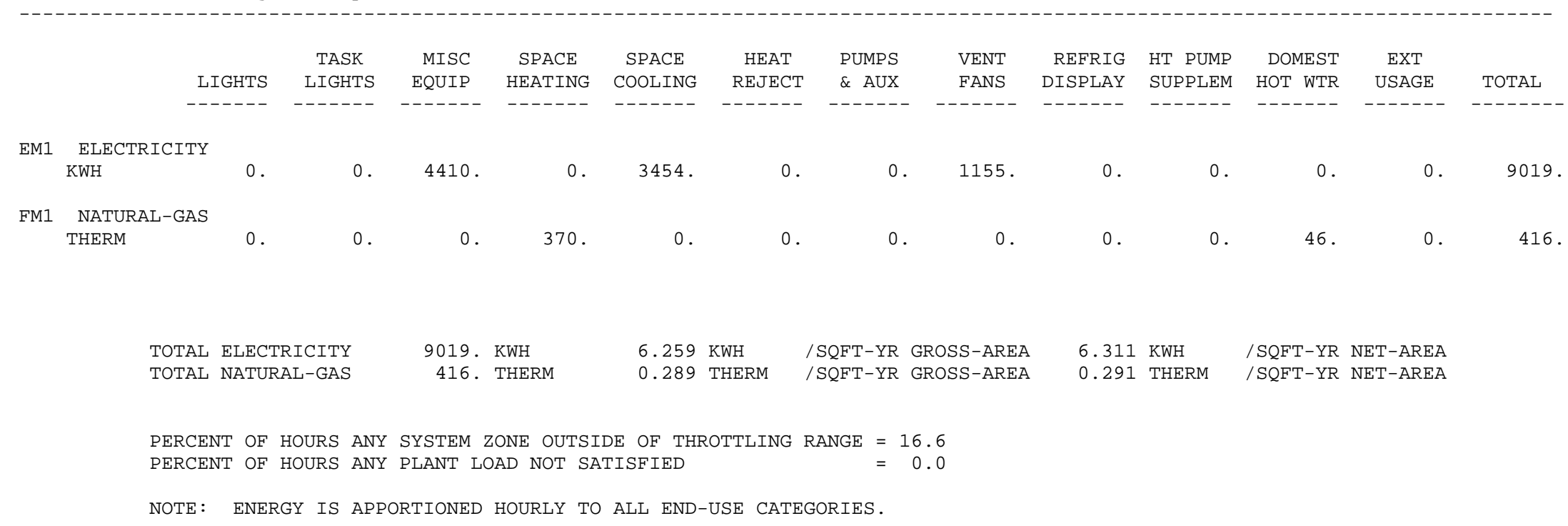




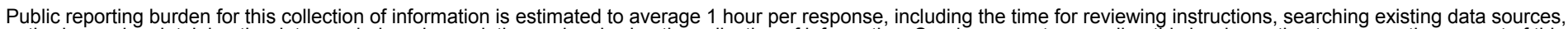

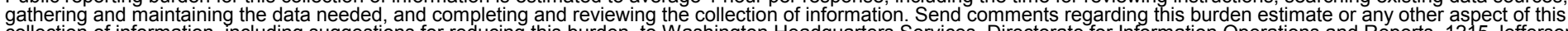

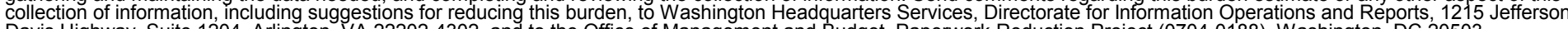

Davis Highway, Suite 1204, Arlington, VA 22202-4302, and to the Office of Management and Budget, Paperwork Reduction Project (0704-0188), Washington, DC 20503.

\begin{tabular}{|l|l|l|}
\hline 1. AGENCY USE ONLY (Leave blank) & $\begin{array}{l}\text { 2. REPORT DATE } \\
\text { September } 2001\end{array}$ & $\begin{array}{l}\text { 3. REPORT TYPE AND DATES COVERED } \\
\text { Technical report }\end{array}$ \\
\hline
\end{tabular}

4. TITLE AND SUBTITLE

Building America House Performance Analysis Procedures

5. FUNDING NUMBERS

BET1.8004

6. AUTHOR(S)

Robert Hendron; Sara Farrar-Nagy; Ren Anderson; Ron Judkoff; Paul Reeves; Ed Hancock

\section{PERFORMING ORGANIZATION NAME(S) AND ADDRESS(ES)}

National Renewable Energy Laboratory

1617 Cole Blvd.

Golden, CO 80401

9. SPONSORING/MONITORING AGENCY NAME(S) AND ADDRESS(ES)
8. PERFORMING ORGANIZATION REPORT NUMBER

NREL/TP-550-27754

10. SPONSORING/MONITORING AGENCY REPORT NUMBER

\section{SUPPLEMENTARY NOTES}

12a. DISTRIBUTION/AVAILABILITY STATEMENT

National Technical Information Service

U.S. Department of Commerce

5285 Port Royal Road

Springfield, VA 22161 12b. DISTRIBUTION CODE

\section{ABSTRACT (Maximum 200 words)}

As the Building America Program has grown to include a large and diverse cross section of the home building industry, accurate and consistent analysis techniques have become more important to help all program partners as they perform design tradeoffs and calculate energy savings for prototype houses built as part of the program. This document illustrates some of the analysis concepts proven effective and reliable for analyzing the transient energy usage of advanced energy systems as well as entire houses. The analysis procedure described here provides a starting point for calculating energy savings of a prototype house relative to two base cases: builder standard practice and regional standard practice. Also provides building simulation analysis to calculate annual energy savings based on side-by-side short-term field testing of a prototype house.

\section{SUBJECT TERMS}

Building America; energy savings analysis; simulation analysis; calculation of annual energy savings; prototype house; testing

\begin{tabular}{l|l}
$\begin{array}{l}\text { 17. SECURITY CLASSIFICATION } \\
\text { OF REPORT }\end{array}$ & $\begin{array}{l}\text { 18. SECURITY CLASSIFICATION } \\
\text { OF THIS PAGE } \\
\text { Unclassified }\end{array}$ \\
\hline
\end{tabular}

NSN 7540-01-280-5500

19. SECURITY CLASSIFICATION
OF ABSTRACT
Unclassified

\section{SECURITY CLASSIFICATION} Unclassified

\section{NUMBER OF PAGES}

16. PRICE CODE

20. LIMITATION OF ABSTRACT UL

Standard Form 298 (Rev. 2-89) Prescribed by ANSI Std. Z39-18 